NBER WORKING PAPER SERIES

\title{
AFRICA'S MANUFACTURING PUZZLE: EVIDENCE FROM TANZANIAN AND ETHIOPIAN FIRMS
}

\author{
Xinshen Diao \\ Mia Ellis \\ Margaret S. McMillan \\ Dani Rodrik \\ Working Paper 28344 \\ http://www.nber.org/papers/w28344
NATIONAL BUREAU OF ECONOMIC RESEARCH
1050 Massachusetts Avenue
Cambridge, MA 02138
January 2021, Revised February 2021

\begin{abstract}
We thank the National Bureau of Statistics in Tanzania and the Central Statistical Agency in Ethiopia for providing access to the data as well as invaluable support in creating and cleaning the panels, Inigo Verduzco for his work creating the Ethiopia panel identifiers for 1996-2013, Andualem Telaye Mengistu and his team at the Ethiopian Development Research Institute and Oxford University for providing access to their matching process for the Ethiopia panel for 2013-2017, Brian McCaig for information about Vietnam, Gaaitzen de Vries and Emmanuel Mensah for their feedback on total manufacturing employment estimates, and Marco Sanfilippo for helpful discussions. Feiruz Mohammed provided excellent research assistance. We are grateful to PEDL and the FCDO for financial assistance and to the CGIAR's research program Policies, Institutions, and Markets (PIM) led by the International Food Policy Research Institute for its support. The views expressed herein are those of the authors and do not necessarily reflect the views of the National Bureau of Economic Research.
\end{abstract}

NBER working papers are circulated for discussion and comment purposes. They have not been peer-reviewed or been subject to the review by the NBER Board of Directors that accompanies official NBER publications.

(C) 2021 by Xinshen Diao, Mia Ellis, Margaret S. McMillan, and Dani Rodrik. All rights reserved. Short sections of text, not to exceed two paragraphs, may be quoted without explicit permission provided that full credit, including $(\odot$ notice, is given to the source. 
Africa's Manufacturing Puzzle: Evidence from Tanzanian and Ethiopian Firms

Xinshen Diao, Mia Ellis, Margaret S. McMillan, and Dani Rodrik

NBER Working Paper No. 28344

January 2021, Revised February 2021

JEL No. O1,O14

\begin{abstract}
$\underline{\text { ABSTRACT }}$
Recent growth accelerations in Africa are characterized by increasing productivity in agriculture, a declining share of the labor force employed in agriculture and declining productivity in modern sectors such as manufacturing. To shed light on this puzzle, we disaggregate firms in the manufacturing sector by size using two newly created panels of manufacturing firms, one for Tanzania covering 2008-2016 and one for Ethiopia covering 1996-2017. Our analysis reveals a dichotomy between larger firms that exhibit superior productivity performance but do not expand employment much, and small firms that absorb employment but do not experience any productivity growth. We suggest the poor employment performance of large firms is related to use of capital-intensive techniques associated with global trends in technology.
\end{abstract}

Xinshen Diao

Development Strategy and

Governance Division

International Food Policy

Research Institute

2033 K Street NW

Washington, DC 20006

x.diao@cgiar.org

Mia Ellis

IFPRI

1201 Eye Street

Washington, DC 20005

m.ellis@cgiar.org
Margaret S. McMillan

Tufts University

Department of Economics

114a Braker Hall

Medford, MA 02155

and International Food Policy Research Institute

and also NBER

margaret.mcmillan@tufts.edu

Dani Rodrik

John F. Kennedy School of Government

Harvard University

79 J.F. Kennedy Street

Cambridge, MA 02138

and NBER

dani_rodrik@harvard.edu 


\section{Introduction}

Before Covid-19 struck, many economies in Sub-Saharan Africa were expanding rapidly -- faster than at any time since independence. While some of the larger and resource-dependent economies had slowed down due to the softening of commodity prices, others such as Ethiopia, Rwanda, and Cote $d^{\prime}$ Ivoire were still registering annual growth rates in excess of 7 percent. Superficially, these rapidly growing economies were going through the classic structural change scenario: workers were leaving agriculture, and urban populations and occupations were expanding. Moreover, the productivity gains generated by this process of structural change accounted for a significant proportion of overall growth (as we showed in Diao et al., 2019).

Yet African growth accelerations were anomalous when viewed from the perspective of comparative development patterns. Aggregate labor productivity growth within manufacturing and other modern sectors has been disappointing. In fact, those countries where growth-promoting structural change was significant (Ethiopia, Malawi, Senegal, and Tanzania, especially) experienced negative to zero labor productivity growth within their non-agricultural sectors (Diao et al., 2019). This is especially puzzling in the case of manufacturing, the canonical modern sector. And it is the case not just for resource-dependent countries, but also for others such as Ethiopia that have made significant progress in attracting foreign investment in manufacturing from China and elsewhere (Abebe et al., 2018).

These facts are not consistent with a process of growth driven by productive improvements in manufacturing and other modern sectors (a supply-side model of growth). We argued in Diao et al. (2019) that a demand-side story presents a more plausible account. An increase in demand for urban products - whether due to transfers from abroad, public expenditures, or income gains in agriculture could explain the observed structural-change patterns. It would also explain why productivity in the more modern parts of the economy lagged or declined: increased demand for modern-sector output could be met only through an expansion of less productive firms and activities at the margin. This perspective therefore made us skeptical about the sustainability of these growth accelerations.

We begin this paper by confirming the negative correlation between growth-promoting economy-wide structural change, on the one hand, and labor productivity growth within nonagricultural sectors, on the other, for an expanded set of African countries. This analysis is based on the GGDC 10 Sector Database updated with the Expanded Africa Sector Database (EASD), such that it now 
includes 18 African countries through 2015 (compared to 11 previously through 2010) (Mensah et al., 2018). Zeroing in on the manufacturing sector, we next compare employment trajectories in Taiwan and Vietnam to those in Tanzania and Ethiopia. In all four cases we split manufacturing employment into firms with 10 or more employees (formal) and the remainder (small and/or informal) by combining UNIDO's Indstat2 data with the GGDC data. The contrast is stark. The share of formal sector manufacturing employment took off during the growth accelerations in Taiwan and Vietnam. In Tanzania and Ethiopia, it is the share of employment in small and informal firms that has expanded during the period of growth acceleration. ${ }^{1}$

Why isn't the share of formal manufacturing employment expanding more rapidly in Tanzania and Ethiopia? To better understand this, we take a closer look at the manufacturing sectors in each of these countries. The core of our analysis rests on two newly created panels of manufacturing firms, one for Tanzania covering 2008-2016 and one for Ethiopia covering 1996-2017. In both cases, the panel covers firms with 10 employees or more. But in the case of Ethiopia, we are able to supplement our analysis with nationally representative surveys of small-scale manufacturing firms employing fewer than 10 workers, which are available for 2002, 2006, 2008, 2011, and 2014. With these data, we are able to take a finer-grained look at employment and productivity patterns within manufacturing firms and subsectors.

Our findings shed light on the nature and sources of manufacturing under-performance. In both countries, there is a sharp dichotomy between larger firms that exhibit superior productivity performance but do not expand employment much, and small firms that absorb employment but do not experience any productivity growth. The problem lies not in the productivity performance of the larger firms, which is more than adequate, but in their inability to generate employment opportunities. The labor absorbing firms, by contrast, are the smaller ones on significantly worse productive trajectories.

We argue that standard explanations for the lack of employment growth in the most productive manufacturing firms are inadequate. First, the size distribution of firms in both countries combined with the fact that smaller firms are considerably less productive than large firms casts doubt on the idea that

\footnotetext{
${ }^{1}$ See also Oqubay (2018) on Ethiopia's manufacturing sector. Oqubay notes that Ethiopian manufacturing (until 2016-17) had played a marginal role in employment creation, exports, and output, and fell short in stimulating domestic linkages. While Oqubay expresses more optimism about the future of the manufacturing sector, he acknowledges that its' disappointing employment performance is likely to be due to a combination of high capital intensity of firms, intense pressure to increase productivity and the shrinking of public sector enterprises.
} 
financing and other constraints prevent small firms from growing into large firms that would employ more workers (Hsieh and Olken, 2014). Second, high labor costs in Africa are sometimes cited as a constraint on industrialization in Africa (Gelb et al., 2020). But we find that the payroll share in total value added in both Tanzania and Ethiopia is exceedingly low overall (11-12\%) and also in garments and textiles (20-24\%). And third, explanations based on the poor business environment in Africa are at odds with the dynamism in both countries manufacturing sectors captured in our analysis of entry and exit. In fact, entry and exit patterns in Tanzania and Ethiopia are not too dissimilar from those in Vietnam.

Instead, we suggest the problem might lie with the nature of technologies available to African firms. We show that the relatively large firms in the manufacturing sectors of Tanzania and Ethiopia are significantly more capital-intensive than what would be expected on the basis of the countries' income levels or relative factor endowments. This is especially true of the larger, most productive firms, where capital intensity approaches (or exceeds) levels observed in the Czech Republic, a country that is around twenty times richer. High levels of capital intensity (and possibly of skill intensity as well, though we do not measure that) are an important reason behind the poor employment performance of productive firms.

Why do firms in Tanzania and Ethiopia use production techniques that may not be particularly appropriate to the local economy? It is possible that they do not have much choice. Two things have happened in recent decades that push firms in that direction. First, manufacturing has experienced significant technological change in advanced economies. Naturally, innovation has taken a direction that responds to relative factor prices in the settings where it has taken place. So, it has been markedly laborsaving. Secondly, globalization and the spread of global value chains has had a homogenizing effect on technology adoption around the world. This means that the range of substitution between capital and low-skill labor has likely shrunk. The imperative of competing with production in much richer countries at similar quality levels makes it difficult to undertake large shifts in technique.

Unlike earlier waves of developing nations, Tanzania and Ethiopia joined the world economy at a point where these two trends were already well established. Meanwhile they are still poor and have very low relative capital endowments. This creates a conundrum: competing with established producers on world markets is only possible by adopting technologies that make it virtually impossible for significant amounts of employment to be generated. 
The outline of the paper is as follows. We begin in section 2 by providing a macro overview of structural transformation in Africa. Using updated data, we confirm the trends we discussed in Diao et al. (2019). We compare Tanzania and Ethiopia to two East Asian cases, Taiwan and Vietnam, to highlight the anomalous expansion of small and informal manufacturing employment in the former cases. In section 3, we describe our data, newly constructed firm-level panels for Tanzania and Ethiopia, and their construction. In section 4, we present the results of firm-level regressions where we relate productivity and employment levels and growth rates to firm characteristics such as size, ownership, and export orientation. We present a number of robustness checks and also present comparable results at the industry level. This section documents the dichotomy between the large and small firms we have noted above. Section 5 takes a closer look at productivity dynamics. We ask in particular whether less productive firms catch up to the more productive firms, and if so, whether this produces lower dispersion in productivity performance across firms over time. The answers are yes and no, respectively. In section 6 we document the capital-intensity of Tanzanian and Ethiopian manufacturing firms, across different firm categories, taking the Czech Republic as our main comparative benchmark. We also present and discuss our interpretation of this result. Section 7 offers concluding remarks.

\section{Macroeconomic Evidence}

In previous work we documented a puzzling pattern of growth in African countries using data from the Groningen Growth and Development Centers' (GGDC) 10 Sector Database (Diao et al., 2019). We found that rapid aggregate labor productivity growth in Africa had been accompanied by weak to negative labor productivity growth in these countries' non-agricultural sectors. In this section, we update those results with updated GGDC-EASD data (Mensah et al., 2018), which confirms our earlier results. An advantage of the updated GGDC data is that it covers an additional 7 African countries bringing the total to 18 . We then present aggregate evidence from the manufacturing sectors in Ethiopia, Tanzania, Taiwan, and Vietnam consistent with the idea that the growth patterns in Africa are demand driven while those in Asia are supply driven. Finally, we show that increases in agricultural productivity in Ethiopia and Tanzania coincide with an expansion of the share of small and informal firm manufacturing employment in these two countries.

\subsection{Recent Patterns of Growth}

As in our previous work, we decompose economywide labor productivity growth into its' between (structural change) and within components; an extensive discussion of the decomposition is 
provided in Diao et al. (2019). To home in on Africa's modern sectors, within sector labor productivity growth is further decomposed into agriculture and an employment-weighted average of the manufacturing, trade services, business services, construction, and transport sectors. Figure 2.1 replicates the patterns shown in Diao et al. (2019) using the updated GGDC-EASD numbers. The bars in Figure 2.1 are coded according to how much of labor productivity growth comes from structural change (in grid) and how much comes from within-sector labor productivity growth in agriculture (in diagonal lines) and in non-agriculture (in black). The main difference between Figure 2.1 and our previous results is that including the additional African countries shrinks the contribution of within nonagricultural sector productivity growth to close to zero.

Figure 2.1 shows that in Africa, prior to the growth acceleration average annual labor productivity growth is minimal at around a half a percentage point; the within-sector non-agricultural component of labor productivity growth is negative. After the growth acceleration, structural change contributes significantly to growth in Africa. This is not surprising since we expect the payoff to structural change to be greatest in poor countries. However, the contribution of within-sector labor productivity growth in the non-agricultural sector is close to zero. This is troubling in the sense that were this pattern to continue, labor productivity growth outside agriculture would eventually peter out.

Figure $2.2 \mathrm{a}$ is a scatter plot of the relationship between within-sector productivity growth (in the nonagricultural sector only, horizontal axis) and the labor productivity growth that arises as a result of structural change (vertical axis) for African countries. The pattern revealed by Figure 2.2a is a negative correlation between these two components of overall growth. The five non-agricultural sectors are denoted by the different shapes in the legend; manufacturing is represented by a shaded circle. Turning to the manufacturing sector in Tanzania, Figure 2.2a shows that the contribution of the manufacturing sector to within-sector labor productivity growth is close to zero while its contribution to growth from structural change is about 0.5 percentage points. In Ethiopia, the contribution of the manufacturing sector to within-sector labor productivity growth is -0.18 percentage points while its contribution to growth from structural change is almost 0.6 percentage points.

For comparative purposes, Figure 2.2b shows the same correlation for seven Asian countries during the first 10 years of their initial growth accelerations. In contrast to the African countries, the Asian countries exhibit a positive correlation between the within and structural change components of labor productivity growth for each specific nonagricultural sector. In all seven countries, the manufacturing sector contributed positively to within-sector labor productivity growth and the growth 
that comes from structural change. For example, the manufacturing sector in Thailand contributed around 0.55 percentage points to growth from structural change; this is very similar to the numbers for Ethiopia and Tanzania. But unlike Ethiopia and Tanzania, within sector labor productivity growth in Thailand's manufacturing sector was about 1 percentage point.

Summarizing, in Asia well-performing nonagricultural sectors have contributed to economywide productivity growth both by drawing labor from lower-productivity sectors and by experiencing rapid productivity improvements. In Africa sectors outside of agriculture have not performed well and have only contributed to economywide labor productivity growth through structural change. To gain a better understand for the underlying causes of these patterns, we turn to data from the manufacturing sector.

\subsection{Explaining Patterns of Growth: Manufacturing Employment Trends}

The patterns described in Africa relative to Asia are especially puzzling when it comes to manufacturing, the canonical "modern" sector. In our previous work we hypothesized that these patterns might be explained by differences in the sources of structural change. We developed a simple model to highlight the differences between demand- and supply-driven structural change. Supply-driven structural change in our model was captured by a positive productivity shock to the modern sector (in this case manufacturing) allowing it to draw labor from other, less productive sectors of the economy. By contrast, in our model demand-driven structural change was a result of positive aggregate demand shocks possibly as a result of public investment, external transfers, or increases in rural incomes. In practice, the aggregate demand shock is likely the result of a combination of all three.

One symptom of these underlying differences in the roots of structural change relates to differential growth rates in formal and informal sector manufacturing sector employment trends across the two continents. To the extent that structural change is supply driven we would expect to see an expansion of modern sector (or formal) activity in the manufacturing sector. Demand driven structural change on the other hand is likely to be accompanied by the entry of less productive or informal manufacturing firms at the margin.

To explore this hypothesis, we use sector level employment data for manufacturing from the GGDC-EASD database combined with manufacturing employment data from the United Nations Industrial Organization (UNIDO) INDSTAT2 2019 database. The GGDC manufacturing employment data is largely based on population census data and so covers manufacturing in both the formal and informal sectors (Timmer, de Vries and de Vries, 2015). By contrast, INDSTAT2 records manufacturing 
employment data for formal sector firms in the manufacturing sector (UNIDO, 2020). Although country statistics sometimes vary in terms of the size of establishments covered, typically INDSTAT2 covers firms with 10 or more employees. For each of Tanzania, Ethiopia, Taiwan, and Vietnam, we compute small and informal sector employment in the manufacturing sector as the difference between total employment (GGDC) and formal sector employment (INDSTAT2). We then plot total, small and informal and formal sector manufacturing employment for each of these four countries.

We gauge the accuracy of the recent total manufacturing employment numbers reported in the EASD using estimates of manufacturing employment based on firm level datasets and living standards measurement surveys (LSMS). This exercise lead to a reduction in total employment in manufacturing in recent years but no change in the aggregate patterns. A summary of these results can be found in Table A.1 in the appendix.

Figure 2.3a shows the results of this exercise for Ethiopia and Tanzania. The most striking trends common to both countries are the upward sloping curves for employment in small and informal manufacturing employment and the relatively flat lines for formal sector manufacturing employment. ${ }^{2}$ The vertical lines in each graph mark the start of the growth acceleration; growth accelerates in 1998 in Tanzania and in 2000 in Ethiopia. The beginning of the rise in small/informal sector employment coincides with the beginning of the growth acceleration in both Tanzania and Ethiopia. Alongside the INDSTAT2 employment data, we also plot formal sector employment data in each country using their respective manufacturing censuses (these data are described extensively in Section 3 and in Appendix 1). The INDSTAT2 series and the series of formal sector employment data coincide almost perfectly. This is not surprising since UNIDO obtains its' manufacturing employment data from national statistical agencies; still it is reassuring since we do not have firm level census data for the Asian countries.

Figure 2.3b shows starkly different patterns for Taiwan and Vietnam. As with the graphs for Africa, the vertical lines represent the beginning of each countries' growth acceleration, 1960 for Taiwan

\footnotetext{
${ }^{2}$ One positive recent development in Ethiopia, cited by Oqubay (2018), is the increase in manufacturing FDI between 2012 and 2016: manufacturing FDI increased from around 1 billion USD to 3.5 billion USD. A related development is the expansion of employment in industrial parks from around 14 thousand employees in 2013 to around 55 thousand employees in 2017 (EIC, 2019). The number of employees in industrial parks at the end of 2019 - prior to the onset of Covid 19 - was around 68 thousand (EIC). Yet total employment growth in large and medium scale enterprises remains low at between 1.5 and 4 percent per year depending on the definition of employment. This is in stark contrast to the growth of employment in small scale enterprises of around 17 percent per annum.
} 
and 1993 for Vietnam. Unlike the African cases, formal sector manufacturing employment in Taiwan and Vietnam grows rapidly for several decades following the growth acceleration. Over these same periods, employment in small/informal firms remains relatively flat and even starts to decline slightly in Vietnam after 2005. Both Taiwan and Vietnam were largely agrarian societies before the start of their growth accelerations (Huang, 1993; McCaig and Pavcnik, 2017). Although not shown, increases in formal manufacturing sector employment in these two countries coincided with gradual declines in agricultural employment shares. These stylized facts are consistent with the idea that structural change in these two countries was a result of positive supply shocks to the manufacturing sector.

One final piece of evidence supports the idea that expansion of "modern" sectors in Tanzania and Ethiopia has been demand driven. In Figure 2.4, we plot the relationship between labor productivity in agriculture, and employment in small/informal sector manufacturing employment and formal sector manufacturing employment as a share of total employment based on the GGDC-EASD employment numbers. Labor productivity in agriculture is calculated using GGDC data on value added and employment in agriculture and indexed to 1970. Both graphs show that the reversal in labor productivity growth in agriculture coincides with the beginning of the rise in the small/informal share of employment in manufacturing. Thereafter, the two series are strongly positively correlated. Equally striking is the relatively flat line corresponding to the employment share in formal sector manufacturing. Presumably increases in labor productivity in agriculture are associated with rising rural incomes providing further support for the hypothesis that structural change has been driven by demand shocks in these two countries.

Finally, our estimates of labor productivity growth in agriculture using the GGDC data are corroborated by other researchers. Using data from FAOSTAT, Badiane et al. (forthcoming), find rising agricultural output per worker in many African countries, including Tanzania and Ethiopia. And the World Development Indicators show that real agricultural output per worker in SSA grew 50 percent from 2000 to 2014; total cumulative growth from 2000-2014 was 29 percent in Tanzania and 68 percent in Ethiopia.

\subsection{Summary}

The evidence presented so far seems to indicate that formal sector manufacturing firms in Tanzania and Ethiopia have not absorbed large numbers of workers. The opposite is true for Taiwan and Vietnam. This evidence is consistent with previous work where we hypothesized that structural change 
in African countries -- expansion of manufacturing and other urban "modern" sectors -- has been demand driven. In addition, the results for the formal manufacturing sectors in Ethiopia and Tanzania are somewhat surprising. Tanzania and Ethiopia have both made industrialization cornerstones of their growth plans. And Ethiopia has been heralded as the China of Africa in numerous news outlets. Its low wages and generous incentives for foreign investors have been viewed as omens of successful industrialization.

Yet we know little about the progress of industrialization in these two countries. Why is formal manufacturing sector employment lagging? Are formal manufacturing firms in Tanzania and Ethiopia performing poorly? To answer these questions, we turn to firm level analyses of the manufacturing sector in each of these two countries using newly constructed longitudinal data for the period 2008-16 for Tanzania and 1996-2017 for Ethiopia.

\section{The firm-level data}

Analyses of manufacturing trends in low-income Africa have been hampered by data limitations. This paper makes use of two newly created panels of manufacturing firms, one in Tanzania covering 2008-2016 and one in Ethiopia covering 1996-2017. ${ }^{3}$ In this section we describe these datasets, their construction, cleaning, and shortcomings; we also present summary statistics.

We created the Tanzanian panel dataset for the period 2008-2016 from repeated years of the Annual Survey of Industrial Production (ASIP), conducted by the National Bureau of Statistics (NBS) of Tanzania. The Tanzanian government has conducted the Annual Survey of Industrial Production (ASIP) since the early 2000s and published the ASIP analytical and statistical reports routinely since 2008 (NBS, 2010a, 2010b, 2012, 2016a, 2016b, 2018a, 2018b). ASIP is meant to cover all industrial establishments in the country that employ ten persons or more. This includes mining, manufacturing, and utilities sector firms. We limit our work and analysis to the sample of manufacturing sector firms.

We created the Ethiopian panel dataset for the period 1996-2017 from repeated years of the Large and Medium Scale Manufacturing Industries Survey, conducted by the Central Statistical Agency (CSA) of Ethiopia (CSA 2001, 2004, 2008, 2011a, 2011b, 2011c). This survey is meant to cover all manufacturing establishments in the country that employ ten persons or more and that use power-

\footnotetext{
${ }^{3}$ The ASIP and LMSM surveys are not currently available publicly, though researchers can request access to the data from NBS and CSA, respectively. Additionally, both the NBS and CSA have granted us permission to make the panel datasets publicly available in the future.
} 
driven machinery. While the LMSM survey does not cover mining, it does include some utilities firms. As such, we limit our analysis to the sample of manufacturing firms.

\subsection{Panel Creation and Cleaning}

The Tanzania panel was created from annual ASIP data obtained from the NBS for the period 2008-2016; there was no survey in 2014. NBS assigned consistent firm identifiers across the years 20082016, which were a combination of the firm's location information and a sheet and batch number. Using these identifiers, we were able to match firms over multiple years of the ASIP and create a firm-level panel. There were some changes to the questionnaire over time, but key variables are consistently reported.

The Ethiopia panel creation process was more complicated, due to a lack of consistent panel identifiers after 2011. We obtained datasets from CSA for each year of the LMSM from 1996-2017, apart from 1997, which was never made available. In each year, an establishment is identified by the combination of its ISIC code and an establishment number. The establishment number is unique within each ISIC group and LMSM round but not necessarily consistent across LMSM rounds after 2011. This is the crux of the problem we faced when creating the LMSM panel.

To merge the different rounds of LMSM establishment-level datasets into a single panel, this required cross-verification of establishment's identities across different data sources and across years. The work to merge the 1996-2013 panel was done before the data for the years 2014-2017 were fully available. As a result, there are two distinct merging processes, one that created a panel from 19962013 and one that created a panel from 2013-2017. Both relied on manual, case-by-case matching processes but were conducted by different teams.

The panel identifiers for 1996-2013 were created through work by Abebe et al. (2018), and we use their panel identifiers and correspondence file to merge the individual datasets from 1996-2013. That team tried several ways to match establishments across LMSM rounds and there was no single type of matching algorithm (automatic, e.g., fuzzy matching) that resulted in satisfactory results. Consequently, they relied on assessing matches on a case-by-case basis using all available information, including the establishment census framework lists CSA used for different LMSM rounds and hard copies of LMSM questionnaires CSA had in storage. 
For the years 2013-2017, which were merged through a separate process by a team of researchers based at the Ethiopian Development Research Institute and Oxford University, largely relied on firm ISIC code, establishment number, taxpayer identification number, phone number, and establishment name. The final panel spans the period 1996-2017 and was created by merging the early and later panels using the CSA unique firm identifiers (ISIC code and establishment number) in 2013. In the final Ethiopia panel, about 16 percent of the sample is only observed once, accounting for about 10 percent of both total employment and total value added. This compares to 12 percent of the panel in Tanzania, which accounts for 9 percent of total employment and 12 percent of total value added.

After creating the merged ASIP and LMSM panels, we then went through a cleaning process to check the quality of the data and flag any problematic observations. We focused on several key variables needed for our analyses, including employment, the components of output and intermediate costs, wages, and capital stock. This included correcting obvious inputting errors such as employment in the hundreds of thousands, and interpolating missing values for employment, sales, and raw materials costs where possible.

More details on the panel creation and cleaning process can be found in the online appendix. In all analyses using the firm-level data, we focus on results from Winsorized samples. In addition, for our analyses of employment and labor productivity growth we present both firm-level results and sectorlevel results as checks on the reliability of the matching process and as an informal way of accounting for firm entry and exit.

\subsection{Coverage of the Census Data}

Both censuses are meant to cover all firms operating with 10 or more employees. However, since we are among the first researchers to use the firm level data in Tanzania, we use other sources of information to verify aggregate employment estimates.

Tanzania maintains a Central Registry of Establishments (CRE), which records data on establishments in all sectors and of all sizes. With assistance from NBS we compared estimates of the number of manufacturing firms in the CRE in the years for which this information had been formally tabulated-2008, 2009, 2010, and, 2014-broken up by employment size class. When comparing the ASIP to the CRE, we find that the coverage of large firms (those with 50 or more workers) is consistently high. The coverage of small firms is seemingly low in earlier years (2008-2010), but this may be 
explained by the fact that CRE records all registered establishments while ASIP requires that the firm was operational in the reference year.

We also compare the estimates of employment in manufacturing from the ASIP panel to estimates from the Tanzania National Panel Survey (NPS), which covers the years 2009, 2011, 2013 and 2015 (NBS 2009, 2011, 2013, 2015). These data are publicly available from the World Bank Living Standards Measurement Study (LSMS) project, which supported NBS in its design and implementation of the NPS. From those data, we compute weighted estimates of employment in manufacturing firms with 10 or more workers that is similar in magnitude to the estimates produced by ASIP. There are also specific concerns about the 2013 ASIP data, which we find has low coverage of small firms (with 10-49 workers). This is likely explained by the fact that the 2013 data come from the 2013 Census of Industrial Production (CIP). The CIP aimed to cover industrial firms of all employment sizes; the enumeration process included a full census of firms with 10 or more workers (identical to the ASIP) and a sample of firms with fewer than 10 workers. The sheer size of the operation involving firms of all sizes leads to smaller sample sizes even for small firms with 10 or more employees. Therefore, we apply sampling weights to the 2013 data although in practice weighted and unweighted results are almost identical.

We also have some minor concerns about the coverage of the Ethiopia LMSM data in the later years because it is unclear whether the LMSM covers firms in industrial parks. To check this, we obtained a complete list of industrial parks and their initial year of operation and of the firms operating in these parks and their employment status produced by the Ethiopian Investment Commission in 2019. Between 2013-2016 two industrial parks were established; one in 2013 and one in 2016. Using firm names, we match firms in the industrial parks to firms in our panel. In the largest industrial park, Eastern IP, which had been operational since 2013, we were able to match 23 out of 91 firms on the list, accounting for about 40 percent of employment in the park in 2019 or approximately 5,946 workers. In Bole Lemi IP, which opened in 2016, we are able to match 7 out of 11 firms, again accounting for about 40 percent of employees in the park or approximately 6,260 workers.

Given that Bole Lemi opened in 2016 and establishments take time to ramp up production, our growth estimates using the panel data should not be biased by missing employment there. In 2019, we are therefore only concerned about missing a maximum of 8,998 employees in the Eastern IP park; this means that the actual total number of employees missing in the years covered by our panel is likely minimal, as many firms accounting for the missing employment in 2019 will have either opened since 2017 and not be covered in our panel, and other firms will have taken time to grow employment to 2019 
levels. Thus, the missing number of workers from industrial parks operating during the period of our analysis is small enough that it is very unlikely to influence our results.

\subsection{Manufacturing firms with less than 10 employees}

The LMSM and ASIP surveys do not cover firms with fewer than 10 workers. In the case of Tanzania, the only nationally representative data that covers small-scale manufacturers is the 2013 Census of Industrial Production (NBS, 2016b). We use these data to explore the firm size distribution in Tanzania but are unable to analyze employment and productivity growth in these smaller firms. Basic summary statistics are presented in Table 3.1. There are 3 permanent workers on average per firm in the CIP, and the average value added of these firms is USD $2,067 .{ }^{4}$

The CSA In Ethiopia conducts periodic nationally representative surveys of Small-Scale Manufacturing Industries (SSI). The raw data from these surveys is available for 2002, 2006, 2008, 2011, and 2014 (CSA 2003, 2006, 2010a, 2010b, 2014) and covers manufacturing establishments that use power-driven machinery and engage fewer than 10 workers; each of these datasets includes sampling weights. ${ }^{5}$ Although these data are repeated cross sections making it impossible to conduct within-firm analyses, we are able to conduct sector-level analyses of employment and value-added growth.

We present basic summary statistics from the SSI data in Table 3.1. The measures are weighted using the sampling weights provided in the data, and we list both the unweighted and weighted number of observations covered. The data come from 30,647 observations representing 292,202 firms. The average number of permanent workers is low at 3 workers per establishment. However, about one third of these firms also hire an average of 9 seasonal workers per year, and it is common for there to be multiple owners. The average value added of these firms is USD 4,499.

\subsection{Summary Statistics}

We first present maps showing the distribution of firms in our ASIP and LMSM panels as well as the SSI data, in Figure 3.1 for Tanzania and Figure 3.2 for Ethiopia. In both countries the number of large firms has not increased very much, while the number of small firms has expanded considerably. In

\footnotetext{
${ }^{4}$ All USD amounts are reported in 2016 dollars. We convert nominal values in LCU to real 2016 LCU using manufacturing-specific deflators calculated from the WDI data on manufacturing value added in constant and current LCU (World Bank 2020a). We then convert real 2016 LCU to real 2016 USD using the exchange rate between LCU and USD from WDI for both Tanzania and Ethiopia.

${ }^{5}$ The SSI data was made available by Marco Sanfilippo.
} 
Tanzania, shown in Figure 3.1, the number of small firms with 10-49 workers has increased significantly between 2008-2016, and there is new activity in many districts. We see a similar story in Figure 3.2 for Ethiopia, which shows significantly increased numbers of firms with $<10$ workers as well as firms with 10-49 workers across zones in the country.

We next present summary statistics in Table 3.2 corresponding to the sample used in our main analyses in section 4. All currency amounts reported are in real 2016 USD and real 2016 LCU; we took exchange rates from WDI and used WDI manufacturing value-added series to calculate manufacturingspecific deflators (World Bank 2020a). Our ASIP sample covers 3,526 unique firms in Tanzania over 20082016, and firms are observed in the panel on average 2.4 years. Firms in Tanzania have 83 workers on average, average value added is USD 1.7 million (TZS 3.8 billion), and the average value of the capital stock is USD 1.1 million (TZS 2.5 billion). Meanwhile, 25 percent of firms are large (with 50 or more workers), 17 percent are foreign, 10 percent are exporters, and 4 percent are public. ${ }^{6}$

The LMSM sample covers 8,793 unique firms in Ethiopia over 1996-2017, and firms are observed in the data on average 3 years. The average number of workers is 92 , while average value added is USD 1.4 million (birr 30.4 million) and the average value of capital stock is USD 738,000 (birr 16 million). 27 percent of firms in the sample are large, 6 percent are foreign-owned, 5 percent are exporting, and 7 percent are public.

\section{Employment and Labor Productivity in Manufacturing}

In this section we use the datasets described in section 3 to analyze employment and labor productivity in Tanzania and Ethiopia's manufacturing sectors. For much of our analysis, we split firms into small and large groups. Small firms are defined as those with 10-49 workers, while large firms are defined as having 50+ workers. Firms are assigned to the same size class in every year according to their average employment in the first two years observed. To select these size groups, we first split firms into the size groups 10-19, 20-49, 50-99, 100-499, and 500+ workers and tested growth rates in employment, value added, sales, and raw materials (plus each measure in per worker terms). We found that patterns were most consistent between the 10-19 and 20-49 groups and the 50-99, 100-499, and 500+ groups,

\footnotetext{
${ }^{6} \mathrm{~A}$ firm is large if it has 50 workers or more on average in its first two years observed; this is time-invariant. The variables for exporter, foreign, and public are all time-variant and depend on the firm's reporting in the current year. A firm is defined as an exporter if it exports any of its production, defined as foreign if it reports foreign or joint venture ownership, and similarly public if it reports public ownership.
} 
leading us to define a cutoff for small and large firms at 50 workers. A summary of this analysis is provided in Appendix Figures 5.1 and 5.2. ${ }^{7}$

Since our paper is the first to use the ASIP data in panel format and the first to use the LMSM extended panel, we begin with a comparison of employment and labor productivity in levels by firm type. We then present within firm estimates of employment and labor productivity growth by firm type. Next, to account for the impact of entry and exit on aggregate or net employment and labor productivity growth, we estimate labor productivity and employment growth at the industry level. This is followed by a section which addresses concerns in the literature about biases associated with estimating the relationship between firm size and growth without accounting for firm age (Haltiwanger et al., 2013; Martin et al., 2017).

The penultimate section estimates labor productivity and employment growth among smallscale industries in Ethiopia, before concluding with a summary of the results from this section.

\subsection{Employment and Labor Productivity Levels Estimates}

This paper is the first to use the ASIP data in panel format and the first to use the LMSM extended panel. As a result, it is useful to check that we get reasonable outcomes when we compare small firms to large, exporting, foreign owned and public firms using these data. We test this through a set of pooled cross-sectional regressions looking at differences in levels of value added per worker and employment across the years in the panel according to firm characteristics. Our estimating equation is:

$$
\begin{gathered}
\ln \left(y_{i s r t}\right)=\delta_{1}\left({\text { large } \left.\text { firm }_{i t}\right)}+\delta_{2}\left(\text { exporter }_{i t}\right)+\delta_{3}\left(\text { foreign }_{i t}\right)+\delta_{4}\left(\text { public }_{i t}\right)+\mu_{s}+\right. \\
\sigma_{r}+\varepsilon_{i s r t}
\end{gathered}
$$

where $i$ references firm, $s$ industry, $r$ region, and $t$ year; $y_{i s t}$ is the firm's value added per worker or employment. ${ }^{8}$ We examine the relationship between levels of $y_{\text {ist }}$ and firm size, exporter, foreign, and

\footnotetext{
${ }^{7}$ Note that there are almost no mergers and acquisitions in the Ethiopian and Tanzanian manufacturing sectors so estimates of employment and productivity growth reflect real changes and not compositional changes.

${ }^{8}$ Value added is defined as the difference between total sales and total raw materials costs; in Ethiopia, we calculate it as the difference between total sales and total raw materials and utilities costs. Employment in Tanzania is defined as all persons engaged on a regular basis, which includes the number of employees on the permanent payroll, together with any temporary or seasonal workers who have been employed on a weekly or monthly basis for more than one month. In Ethiopia, employment is split into permanent and temporary/seasonal workers. We are missing seasonal/temporary workers for one year of the panel, 2009, so we limit our analysis to permanent workers. However, we do conduct additional robustness checks (available upon request) that show the Ethiopia firm-level growth results are not significantly affected by the inclusion of seasonal/temporary workers in
} 
public status. We also include dummies for each year covered by the panel (reference year 2008 for Tanzania and 1996 for Ethiopia) and include industry and region dummies $\mu_{s t}$ and $\sigma_{r t}$.

We interpret the log-transformed coefficients in Table 4.1 in level terms. After controlling for industry, region, and year, in both countries, large, exporting, and foreign firms all have significantly higher levels of labor productivity and employment. These results confirm our expectations.

The results in column 1 show that in Tanzania, average labor productivity is 95 percent higher in large firms than in small firms (USD 20,861 per worker vs. USD 10,678 per worker) ${ }^{9}$. Labor productivity is 70 percent higher in exporters (USD 25,286) vs. non-exporters (USD 12,571) and 1.1 times higher in foreign firms (USD 20,837) compared to domestic firms (USD 12,245). In Ethiopia, labor productivity is 1.7 times higher in large firms compared to small (USD 114,639 vs. USD 7,080), 56 percent higher in exporters compared to non-exporters (USD 13,028 vs. USD 9,366), and 39 percent higher in foreign firms compared to domestic firms (USD 14,301 vs. USD 9,197).

Employment in Tanzanian large firms is 5.11 times higher than in small firms, with 141 workers on average in large firms compared to 23 in small. Exporters have employment 27 percent higher than non-exporters (87 vs. 55 workers) and foreign firms have employment 57 percent higher than domestic firms (72 vs. 57 workers). In Ethiopia, large firms have 5.3 times more workers than small firms (166 vs. 28 workers), exporters have employment 32 percent greater than non-exporters (103 vs. 78 workers), and foreign firms have employment 86 percent greater than domestic firms (135 vs. 72 workers).

The results are remarkably similar between the two countries. The only differences arise in public firms, which in Ethiopia are similar to the other groups but in Tanzania are quite distinct. In Ethiopia, public firms' labor productivity is 34 percent higher than private firms (USD 12,465 per worker vs. USD 9,313 per worker), and their employment is 1.2 times higher (145 vs. 67 workers per firm). In

\footnotetext{
our employment and labor productivity measures. In these robustness checks, we estimate a full-time equivalent of seasonal/temporary workers by estimating the ratio of production worker wages to seasonal worker wages at the firm-level and applying that ratio to the number of seasonal/temporary workers. On average, we find that 5 seasonal/temporary workers are equivalent to 1 production worker in terms of wages.

${ }^{9}$ All USD amounts are reported in 2016 dollars. We convert nominal values in LCU to real 2016 LCU using manufacturing-specific deflators calculated from the WDI data on manufacturing value added in constant and current LCU (World Bank 2020a). We then convert real 2016 LCU to real 2016 USD using the exchange rate between LCU and USD from WDI for both Tanzania and Ethiopia. We use the margins command in Stata to estimate the predicted value of employment and value added per worker.
} 
Tanzania, labor productivity is 31 percent lower in publicly owned firms compared to privately owned (USD 10,232 in public vs. USD 14,844 in private), and public firms have just 8 percent higher employment than private firms on average (67 vs. 62 workers). This may reflect the fact that public firms are still a large part of the landscape in Ethiopia while in Tanzania most public firms have been privatized. This is supported by the fact that just 4 percent of our sample are public firms in Tanzania, while 7 percent are public in Ethiopia (Table 3.2).

\subsection{Employment and Labor Productivity Growth: Within Firm Estimates}

To describe employment and labor productivity growth and how they vary depending on firm attributes such as size and ownership, we begin by estimating a set of regressions with firm fixed effects in which growth rates are regressed on a linear time trend. Again, we measure firm size based on average employment in the first two years in which the firm appears. Estimating growth in this way gives us an estimate of long run within firm growth by size class which incorporates transitory shocks. (An important issue we do not tackle in this paper is the extent to which small firms transition to large firms and the conditions under which this happens.) In subsequent sections, we explore the extent to which these results are robust to entry, exit and firm age. Thus, the estimating equation is:

$$
\begin{aligned}
& \ln \left(y_{i t}\right)=\beta_{\text {year }}\left(\text { year }_{t}\right)+\delta_{1}(\text { year } * \text { large firm } \text { fit })+\delta_{2}\left(\text { year } * \text { exporter }_{i t}\right) \\
& +\delta_{3}\left(\text { year } * \text { foreign }_{i t}\right)+\delta_{4}\left(\text { year } * \text { public }_{i t}\right)+f_{i}+\varepsilon_{i t}
\end{aligned}
$$

where $i$ references firm, $t$ year, and $f$ are firm fixed effects; $y_{i t}$ is the firm's value added per worker or employment. The coefficients in this regression may be interpreted as the annual average growth in value added per worker and employment.

Table 4.2 shows the results for labor productivity and employment growth in Tanzania and includes interactions with dummy variables for large firms (cols. 2 \& 6), exporting firms (cols. 3 \& 6), foreign firms (cols. $4 \& 6$ ), and public firms (cols. $5 \& 6$ ) in order to check the extent to which growth varies according to firm type.

The top panel of Table 4.2 shows the results for labor productivity growth in Tanzania. We find that labor productivity growth is significantly positive only in large (>50 employees) and exporting firms. Columns 2 and 6 of Table 4.2 show that large firms' labor productivity grows on average at 7-9 percent per year and columns 3 and 6 show that exporting firms grow at 5-6 percent on average per year. Though column 4 shows foreign firms having positive labor productivity growth, column 6 -which 
includes interactions for each type of firm - shows that this effect disappears once we control for the effect of large and exporting firms. This is not surprising given that most foreign firms are either large or exporters or both. The bottom panel of Table 4.2 shows the results for employment growth and reveals that at the firm-level in Tanzania, employment growth in small firms ( $<50$ employees) averages around 1.2-1.3 percent per year. Large firms, on the other hand, have negative employment growth averaging around 2 percent per year. The absence of employment growth in the larger firms that experience positive productivity growth is especially striking.

Table 4.3 shows that in Ethiopia, labor productivity is growing on average across the entire spectrum of firms with more than 10 employees; the upper panel shows that labor productivity grows on average at 2.9-3.2 percent per year. The bottom panel shows that employment within small firms grows from 1-3 percent per year. As in Tanzania, there is evidence that larger firms ( $>50$ employees) have negative employment growth averaging around -1 percent per year; this effect persists even after we control for the positive effects of exporting, foreign, and public firms (which have significant overlap with the large firm group). Average employment growth in exporting firms is around 2.6 percent, in foreign firms is around 2 percent, and in public firms it is around 2.5 percent per year.

\subsection{Entry and Exit: Within Industry Estimates}

In Table 4.4 we report entry and exit over the full sample period for Tanzania and Ethiopia. For comparative purposes, we also include entry and exit in the Vietnamese manufacturing sector, which is reported in McCaig et al. (2020). Following McCaig et al. (2020), we use the initial and final years of the panels to define entry and exit. We call the share of firms in the initial year which do not appear in the final year of the panel exiters; and we call the share of firms that appear in the final year of the panel but not in the initial year entrants. Survivors include two versions of the same group of firms, depending on the reference year: (i) those in the data in the initial year which did not exit (i.e. survived to the final year) and; (ii) those in the final year which were also in the data in the initial year. The relative sizes of the three groups -- entrants, exiters and survivors - is computed as the share of sales or employment relative to the total across all firms in the respective year. For example, in Tanzania between 2008 and 2016, 82 percent of firms exit; these firms account for 78 percent of employment and 73 percent of sales. Thus, survivors are on average larger than exiters.

One concern with the Ethiopian numbers is that errors in our procedure for matching firm identifiers post-2011 could artificially inflate rates of entry and exit. To determine whether the matching 
procedure inflated entry and exit, we also report entry and exit for the period over which the CSA did not change firm identifiers: $2000-2011$. The fourth set of results in Table 4.4 indicates slightly lower (to be expected over the shorter timeframe) but still very high rates of entry and exit. This gives us confidence that our entry and exit rates reflect real activity.

Table 4.4 makes it clear that all three countries experience similarly high rates of entry and exit. We will come back to this point in section 5. For now, a possible concern is that our within-firm estimates of employment and productivity growth may not reflect economywide trends in the presence of such high rates of entry and exit. The issue is especially relevant for the small firms in the sample that often appear in the data only one time.

To account for this, we construct sector aggregates of employment and value-added per worker using the firm-level data and regress these on time. ${ }^{10}$ We do this at the 2, 3, and 4-digit ISIC levels alternatively. We then estimate the following equation (where $s$ denotes sector and $t$ year, and $y$ denotes value added per worker and employment, respectively, and we control for industry fixed effects $\left.\mu_{s}\right):$

$$
\ln \left(y_{s t}\right)=\beta\left(\text { year }_{t}\right)+\mu_{s}+\varepsilon_{s t}
$$

Table 4.5 shows that at the sector level in Tanzania labor productivity growth s positive only among large firms at 7 percent per year. The bottom panel of Table 4.5 shows that employment growth is predominantly taking place among small firms (10-49 employees), with growth of about 10-13 percent per year among sectors aggregated from small firms. It is possible that these small firms are new establishments, but it is also possible that these were existing enterprises that grew to have 10 or more workers and be included in the ASIP.

At the sector-level in Ethiopia, Table 4.6 shows that we find positive net growth in both employment and labor productivity that is consistent across firm size groupings and different ISIC-level aggregations. Labor productivity grows at 4-5 percent and is similar between the aggregations of small and large firms, though slightly higher in the sectors aggregated from small firms. Employment growth is

\footnotetext{
${ }^{10}$ We estimate sector aggregates by taking the sum of value added and employment across all firms at the sector level. We do this at the 2, 3, and 4-digit ISIC levels alternately. In each case, we then calculate the total value added per worker from total sector value added and employment.
} 
higher in the sectors aggregated from small firms, at about 6-7 percent per year on average, while employment growth ranges from 3-6 percent in the sectors aggregated from large firms.

\subsection{Employment Growth, Firm Size and Firm Age}

Haltiwanger et al. (2013) find that once one controls for firm age, the negative relationship between firm size and employment growth disappears and may even reverse sign. This is important since the within firm estimates presented in Section 4.2 give higher weights to older firms. In this section, we explore the relationship between firm age and employment growth following the methodology proposed by Haltiwanger et al. (2013).

First, we compute employment growth using average employment between $\mathrm{t}$ and $\mathrm{t}-1$ in the denominator instead of employment at the beginning or end of the period as follows:

$$
g_{t+1}=\frac{y_{t}-y_{t-1}}{y_{a v g}}
$$

Our estimating equation for employment growth by size and age is as follows:

$$
g_{i j}\left(y_{t+1}\right)=\beta+\beta_{s} s_{i j}+\beta_{a} a_{i j}+X_{i j}+T_{t}+\mu_{j}+\epsilon_{i j}
$$

where $s_{i j}$ is a categorical variable representing the employment size of firm $\mathrm{i}$ in industry $\mathrm{j}$, and $a_{i j}$ is the categorical variable for firm age. We assign a firm to a size category-10-19, 20-49, 50-99, 100-249, 250499, and 500+ workers - based on its average employment in the first two periods observed, and similarly assign it to an age category-1-2, 3-4, 5-6, 7-8, 9-10, 11-13, 13-16, and 16+ years-based on its average age between the first two periods observed. We include a vector of firm controls $X_{i j}$, which include dummies for exporting, foreign, and public status. We also include year dummies $T_{t}$ and control for industry at the 2-digit ISIC level.

The estimates from this equation are presented graphically in Figures 4.1 and 4.2. The figure shows projected employment growth rates for each size and age category. Each pyramid represents projected growth by size and age category, controlling for the other variables in the estimation. Overall, the results shown in Figures 4.1 and 4.2 corroborate our main results; large firms have lower employment growth than small firms irrespective of firm age. 


\subsection{Small Scale Industries}

As we have just discussed, the overall picture looks more favorable for Ethiopia than Tanzania when we focus on the sample of $>10$ firms. Since we have data for $<10$ firms in Ethiopia (SSI firms), we can do a more complete analysis for Ethiopia, but only at the sector level since the SSI is not a panel. Following the estimating equation in section 4.2, we estimate growth in labor productivity and employment among small-scale sectors. For SSI firms, the results in Table 4.7 indicate no statistically significant productivity growth, but strong employment growth (consistent with macro data). These results are consistent throughout alternative definitions of employment. With this, the evidence from Ethiopia evidence becomes more similar to the evidence from Tanzania; employment growth is around $17 \%$ per year but there is little evidence of productivity growth.

4.6 Summary In both Tanzania and Ethiopia large firms, exporters and foreign firms all have significantly higher levels of labor productivity. These results are consistent with a very large theoretical and empirical literature on manufacturing firm performance.

Turning to employment and labor productivity growth, the firm and sector-level results for Tanzania suggest that the best performing firms are not the ones that are absorbing employment. Labor productivity growth in large firms is on the order of 8 percent per year and 13 percent per year for large exporters. By contrast, labor productivity growth in firms with less than 50 employees ranges between negative 3 percent and zero. By contrast employment growth in these small firms is as high as 13 percent.

In Ethiopia, the story is similar although labor productivity growth is not as high as it is in Tanzania. Average within firm employment growth in Ethiopia's large firms is around negative 3 percent per year while it is 3 percent year for firms with between 10 and 49 employees. When we use the industry aggregates, the dichotomy in employment growth between small and large firms persists such that employment growth is 3 percent per year in large firms and 7 percent per year in small firms. To complete the analysis of Ethiopia, we examined a group of mechanized firms with less than 10 employees using the Small-Scale industries survey. Average annual employment growth among these firms is around 17 percent while labor productivity growth is an imprecisely estimated zero. 


\section{Productivity dynamics: convergence and dispersion}

In view of the tremendous heterogeneity among firms - by size, formality, ownership, trade orientation etc. - we take a closer look in this section at patterns of productivity change among our firms. In particular, we ask whether less productive firms tend to catch up to the more productive firms, and if so, whether this produces lower dispersion in productivity performance across firms over time. We first check for productivity convergence at both the firm and industry level (so-called $\beta$ convergence). Then we look for evidence of reduction in productivity dispersion ( $\sigma$-convergence).

The bottom line is that in both Tanzania and Ethiopia there is strong evidence of rapid labor productivity convergence. The evidence is weaker for the smallest firms ( $<10$ employees), for which we have data only in Ethiopia. However, there is no evidence that labor productivity dispersion has come down over time across firms; if anything, the trend is in the opposite direction. The results on dispersion notwithstanding, these findings reinforce the story that the problem with manufacturing in our countries does not lie with productivity performance per se. What stands out is the inability of firms that are either productive or experiencing rapid productivity growth to generate commensurate levels of employment.

At the firm level, we estimate the relationship between growth of labor productivity and its initial level. We are forced to use short time horizons - four years -- because otherwise sample sizes would shrink too much. The basic model we estimate is given by:

$$
\frac{\ln \left(V A P W_{t 4}\right)-\ln \left(V A P W_{t 2}\right)}{t 4-t 2}=\beta_{1} \ln \left(V A P W_{t 1}\right)+e
$$

where VAPW stands for value added per worker, ${ }^{11} t 4$ is the firm's fourth year in the panel, $t 2$ is the firm's second year in the panel, and $t 1$ is the firm's first year in the panel. Note that the initial year $t 1$ is

\footnotetext{
${ }^{11}$ To measure valued added, we add sales and raw materials for Tanzania; sales, raw materials, and utilities for Ethiopia LMSM. Data are winsorized at the bottom and top 1 percentiles (percentiles measured at the firm size and year level for ASIP and LMSM and measured at the industry-year level for SSI). For the Ethiopia SSI results, we calculate an alternate version of value added which is equal to the total gross value of production minus total industrial costs. We use this alternate method because many firms in the SSI data are missing values for either sales or raw materials. However, they do report other types of revenues and costs. In order to include as many SSI firms as possible we therefore adjust our VA equation accordingly.
} 
not used in calculating the labor productivity growth rate to eliminate the bias that arises from $V A P W_{t 1}$ entering on both sides of the equation. We run this regression on the sample of firms that have been in the data for at least four years, controlling for sector (at the 2-digit ISIC code level). We also ran a set of regressions where firms are weighted by their share in total value added; they are not shown here, but we will mention any differences in the discussion below. We also create and introduce dummy variables indicating whether a firm is large (with 50+ employees), an exporter, foreign owned, or public. For each of these categories, we set the dummy value equal to one if the firm meets the criteria in either year.

The results are shown in Table 5.1 and 5.2 for Tanzania and Ethiopia, respectively. In both cases, $\beta$-convergence coefficients are statistically significant, regardless of specification, and quite large. The coefficients are estimated to lie in the $6-8 \%$ for both countries (weighted convergence regressions produce even larger estimated coefficients). For comparison, this coefficient tends to be around $2 \%$ in cross-country (conditional) convergence regressions and around $3 \%$ in (unconditional) convergence regressions for formal manufacturing (Rodrik 2013). Interestingly, we find that the rates of convergence for exporting firms, foreign firms, or larger firms are not statistically distinguishable from that for other firms in either country (cols. 3-5). Convergence holds within each of these groups separately (not shown), but the rates are similar to the average for all firms.

To analyze productivity convergence over a somewhat longer horizon, we next look at convergence across sectors. We create sector-level measures of labor productivity by aggregating value added and employment across sectors and years. We include all firms with non-missing employment and value added (meaning that we do not require firms to be in the data for four years, as we do in the firm-level regressions). We then follow a similar procedure as before but instead estimate convergence across the duration of the panel. For Tanzania, this means that we estimate sector-level growth in labor productivity from 2009 to 2016 and regress growth on the initial 2008 value (Table 5.3). For Ethiopia, we estimate growth between 1998 and 2017, with initial year 1996 (Table 5.4). We show results at different levels of sectoral aggregation, and for both unweighted and weighted regressions. In weighted regressions, sectors are weighted by their share in total value added.

Sector-level convergence regressions yield generally similar results to the firm-level ones, even though the firm coverage and time span are quite different. For Tanzania, the estimated convergence regressions are very much in the same ballpark as in the previous set of results. For Ethiopia, the coefficients are generally smaller, and in some cases (of levels of aggregation) statistically not significant 
at conventional levels. Nevertheless, taken together the results tend to confirm a strong tendency towards labor productivity convergence.

Remember that our baseline sample of firms exclude the smallest firms, with $<10$ employees. For Ethiopia, we can also run these convergence regressions with SSI data, which covers firms with fewer than 10 employees. Because it is not a panel, we can only test convergence at the sector-level. And because we only have five years of SSI data, we estimate growth between 2002 and 2014, with the initial year being 2002. For the SSI sample, we use two alternative definitions of employment: 1) permanent workers, and 2) permanent workers + seasonal \& temporary workers. ${ }^{12}$ We test sector-level convergence for SSI sectors on their own, as well as combining SSI and LMSM sectors together.

The results, shown in Table 5.5, provide much weaker support for productivity convergence among the small firms (<10 employees). When estimated separately (cols. 1-2), the coefficients for LMSM and SSI firms are similar in magnitude, although the latter is not statistically significant. In the pooled regression, (col. 5) we can reject the hypothesis that productivity convergence is as rapid among the small firms as it is among the LMSM firms.

We now turn to $\sigma$-convergence, or dispersion in labor productivity. Here, the evidence is less clear-cut than with $\beta$-convergence. We find no evidence of $\sigma$-convergence. The evidence in fact points in the opposite direction, showing an increase in dispersion in labor productivity in recent years.

We consider four alternate measures of productivity dispersion: coefficient of variation, standard deviation, ratio of $10^{\text {th }}$ to $90^{\text {th }}$ percentile, and ratio of $25^{\text {th }}$ to $75^{\text {th }}$ percentile. The results are shown in Figures 5.1-5.2. In Tanzania, a rough interpretation suggests that productivity dispersion was reducing from 2008 until 2012/2013, before increasing again through 2016. In Ethiopia, we see a general increase in the dispersion indicated by each each measure over the period 1996-2017, though there are ups and down during some sub-periods. When we look at trends within firm groups in Ethiopia (large vs. small, exporter vs. non-exporter, foreign vs. domestic, and public vs. private), we see that dispersion is similarly increasing over the period 1996-2017 for all groups (not shown). In general, small firms have greater productivity dispersion than large firms, non-exporters have greater dispersion than exporters,

\footnotetext{
${ }^{12}$ A third definition of employment, which included "owners," did not yield results that are different, so these are not shown here.
} 
domestic firms have greater dispersion than foreign firms, and public firms have greater dispersion than private firms. All these group-level results accord with our intuition.

The fact that our two measures of convergence go in different directions is not necessarily surprising, as $\beta$-convergence and $\sigma$-convergence measure different things (see e.g., Sala-i-Martin, 1996). $\beta$-convergence is a necessary but not sufficient condition for $\sigma$-convergence. To see this, let's write the growth process (following Sala-i-Martin, 1996) as:

$$
\ln \left(\frac{y_{i t}}{y_{i, t-1}}\right)=a-\beta \ln \left(y_{i, t-1}\right)+u_{t}
$$

Then, if $a$ is identical across firms, Sala-i-Martin shows that the evolution of the variance of $y(\sigma$ convergence) is given by:

$$
\sigma_{t}^{2} \cong(1-\beta)^{2} \sigma_{t-1}^{2}+\sigma_{u}^{2}
$$

When there is $\beta$-convergence ( $\beta$ is between 0 and 1 ), the first term tends to reduce dispersion over time. But whether $\sigma$ goes down overall depends on the second term (the variance of the error term in the growth equation.) It is possible for $\sigma$ to increase if $\sigma_{u}^{2}$ is large enough. That happens when firmlevel idiosyncratic shocks (equivalently, idiosyncratic and non-persistent differences in firm performance) are large enough to outweigh the $\beta$-convergence effect.

Since $\sigma$-convergence measures actual dispersion in firm performance, it is arguably a better indicator of the health of the manufacturing sector. Nevertheless, the evidence on $\beta$-convergence is interesting in its own right. What the results are telling us is that idiosyncratic shocks to productivity dominate the tendency of lower productivity firms to catch up.

\section{$\underline{6 . \text { An interpretation: inappropriate technologies }}$}

The low employment-generation capacity of modern, productive African firms presents a puzzle. It is not clear that we can resolve the puzzle by appealing to conventional culprits. First, note that we find small firms to be less productive than large firms. Consistent with the arguments of Hsieh and Olken (2014), this suggests it is unlikely that credit or other constraints prevent small firms from expanding and growing into larger firms that employ more workers. In particular, we follow Hsieh and Olken (2014) in analyzing the size distribution of firms and reach very similar conclusions. We find no evidence of a "missing middle" in the size distribution of firms in Tanzania and Ethiopia. The distribution of firm size is 
heavily right skewed, with a predominance of small firms and generally a smooth decline in frequency over the firm size distribution. There are no indications of a bimodal distribution. ${ }^{13}$

Second, high labor costs (relative to productivity) are often cited as constraints on employment growth in Africa (e.g. Gelb et al., 2020). But as we will show below, payroll shares in total value added in both Tanzania and Ethiopia are exceedingly low, even in the more labor-intensive sectors. ${ }^{14}$ Third, explanations that posit a "poor business environment" are belied by the high dynamism in Tanzania's and Ethiopia's manufacturing sectors, as captured by our analysis of entry and exit rates. As Table 4.4 shows, entry rates during the two countries' high-growth periods have been as high, if not higher, than the levels observed for Vietnam.

Fourth, institutional aspects of government business relationships are likely to play a role in the evolution of the manufacturing sectors in both Ethiopia and Tanzania; but it is unclear why these relationships would impact the employment growth and not the productivity growth of large firms. Moreover, as pointed out by Bourguignon and Wangwe (2018), corruption is not unique to Tanzania. Of course, corruption is also not unique to Ethiopia. For an extensive discussion of these issues in the Tanzanian context see Bourguignon and Wangwe (2018) and Wangwe and Gray (2018) and in the Ethiopian context see Oqubay $(2015)^{15}$.

In this section, we present an alternative explanation. We argue that the broad patterns we have observed with respect to productivity and employment can be explained by excessively capitalintensive modes of production in manufacturing in our two African economies. We first document the capital intensities of firms in Tanzania and Ethiopia, comparing them to a much richer economy (the Czech Republic). Then we link this technology choice to global innovation patterns in manufacturing in recent decades. In short, the manufacturing technologies on offer on world markets have moved steadily away from the factor proportions of labor-abundant countries. This has made it difficult for African firms to simultaneously enhance productivity and increase employment. Adopting new technologies has meant adopting mostly capital- and skill-intensive technologies and has resulted in less

\footnotetext{
13 These results are available upon request.

${ }^{14}$ In addition, as in Hsieh and Olken (2014), the distributions of the average product of capital and labor are unimodal and do not show any discontinuity, as would be the case if labor costs (or access to finance/capital) were binding constraints on firm growth.

${ }^{15}$ For additional analyses of manufacturing in Africa including Ethiopia and Tanzania, see Newman et al. Made in Africa: Learning to compete in industry, 2016.
} 
price-responsive supply curves. As a result, only the less productive firms retain the ability to absorb significant amounts of labor.

\subsection{Capital-labor ratios in Tanzania and Ethiopia in comparative context}

We choose the Czech Republic as our comparator, a rich country and a successful manufactures exporter. We obtain capital stock values in manufacturing for this economy from the KLEMS database (Stehrer et al., 2019). For Ethiopia and Tanzania, we use our firm-level data to compute capital-labor ratios in manufacturing. We restrict our analysis to firms in the sample for at least two years which allows us to check for coding errors and outliers. We define the capital stock as machinery and equipment (M\&E, excluding transport and ICT equipment) and buildings and structures (B\&S, excluding dwellings) at constant prices. We compute capital stock for M\&E and B\&S separately so that we can apply the appropriate PPP deflators for comparison with the Czech Republic, and then combine them for an aggregate measure of capital. The details of the calculations are explained in Appendix 1.

Some basic comparisons are provided in Table 6.1. Per-capita GDP in our African countries are a small fraction of the Czech level: between 3.5 and 6.6 percent. Aggregate economy-wide capital-labor ratios are similarly tiny: Ethiopia's K/L endowment is 3.4 percent of the Czech level, and Tanzania's 9.9 percent. But when we look at manufacturing specifically, the gaps become much smaller. Ethiopia is nearly at a fifth of the Czech economy and Tanzania at close to a half. In other words, compared to the Czech economy, $\mathrm{K} / \mathrm{L}$ ratios in Africa are 3-4.5 times larger in manufacturing than they are for the entire economy.

Since we have firm-level data for our African economies, we can undertake a finer-grained comparison for specific firm types (Table 6.2). We note in particular that the $10 \%$ most capital-intensive large firms, producing around a quarter of manufacturing value added (but employing less than 10 percent of the manufacturing workforce), have particularly high $\mathrm{K} / \mathrm{L}$ ratios. In Ethiopia these large firms are at 75 percent of the K/L ratio for Czech manufacturing. Tanzania's large firms actually have K/L ratios that significantly exceed those for Czech manufacturing. Moreover, exporting firms are not more laborintensive than the manufacturing average. ${ }^{16}$ This may seem surprising, since we would expect exporting firms to compete on international markets in more labor-intensive segments of manufacturing. But it is

\footnotetext{
${ }^{16}$ Exporting and foreign firms are defined to be time-invariant in order to track the same group of firms over time and produce consistent aggregate estimates. Under the new definitions, foreign firms are defined as those with foreign ownership for the majority of years or at least one year with data available only for two years. Exporters are firms reporting exports in every year.
} 
consistent with the interpretation we shall develop below having to do with the adoption of more capital-intensive global technologies as a precondition for competitiveness. Note also that among large firms, new ones are considerably more capital-intensive than old ones. ${ }^{17}$ This too is consistent with the increased pressure over time to adopt more capital-intensive technologies.

Columns 2-4 of Table 6.2 provide some sectoral detail. We focus on three sectors: food products, beverages, \& tobacco, and, rubber, plastics, \& non-metallic minerals, which are the largest manufacturing sectors in both countries, and garments \& textiles as the main "labor-intensive" sectors. Once again, the surprise is that garments $\&$ textiles does not stand out as a particularly labor-intensive sector. Ethiopian firms are at about 20 percent of the Czech economy, and Tanzanian firms at around 40 percent. We add that comparisons with other OECD economies, much richer than both of our African economies, yield similar ratios (see Appendix Table A2).

It is also instructive to look at trends in manufacturing $\mathrm{K} / \mathrm{L}$ ratios. We can see from Figure 6.1 that the increase in capital-intensity in large manufacturing firms in both Tanzania and Ethiopia has far outstripped economy-wide capital deepening. By contrast, in the Czech Republic not only is capital intensity lower in manufacturing than in the economy as a whole, the two measures have moved more or less in parallel in recent years.

Another striking indicator of low levels of labor-intensity in African manufacturing is the payroll share in total value added. In the Czech economy, the payroll share in aggregate manufacturing is slightly below 50 percent and rises to 57 percent for garments \& textiles (Table 6.3). In Tanzania and Ethiopia, by contrast, the payroll share is in the range of 11-13 percent and rises merely to 20-24 percent in garments \& textiles. It is generally known that labor shares in value added are overstated in developing countries because of the predominance of owner-operated firms. Even accounting for that downward bias, the low payroll share in Tanzania and Ethiopia is striking.

This evidence on payroll shares also suggests that high labor costs - in relation to per capita incomes or level of productivity - cannot account for the capital intensity of our African firms. The extent to which labor costs discourage African industrialization has been an area of debate. Gelb et al. (2020) find that labor costs are in general higher in Africa than would be expected on the basis of income levels. But they also note that there is considerable heterogeneity across the continent. They

\footnotetext{
${ }^{17}$ Firms that enter the sample in 2010 or later are defined as new firms relative to old firms that are in the sample prior to 2010.
} 
point to Ethiopia specifically as an example of low-cost labor, with significant industrialization potential. Blattman and Dercon (2018) also find manufacturing wages to be low in Ethiopia.

In sum, we draw four conclusions from this evidence. First, while K/L ratios in African manufacturing are lower than in much richer comparator nations, these ratios are still much higher than would be expected based on their relative labor abundance and low per-capita income levels. Second, if we focus on the largest firms, $\mathrm{K} / \mathrm{L}$ ratios in Tanzania and Ethiopia are actually comparable to those in much richer OECD countries. Third, exporting firms or the traditionally labor-intensive textiles and clothing firms do not exhibit lower $\mathrm{K} / \mathrm{L}$ ratios than other manufacturing firms on average. Finally, $\mathrm{K} / \mathrm{L}$ ratios have increased much more rapidly in Tanzanian and Ethiopian manufacturing than in the economy as a whole.

\subsection{Biased technological change and premature de-industrialization}

Traditionally, manufacturing has been viewed as a labor-absorbing sector during the process of economic development. As manufacturing industries with higher productivity emerge, labor moves from farming to manufacturing jobs (and associated services) in urban areas. This is the story of the Industrial Revolution, which started the era of modern economic growth, as well as the story of virtually every country that subsequently developed and caught up with the frontrunners. In the post-war period, there was an additional twist with the rapid rise of international trade in manufactured products. This allowed latecomers such as Japan, the East Asian Tigers, and eventually China, to specialize (at least initially) in a narrow range of labor-intensive manufacturing goods for exports. For those countries that were able to engineer it, export-oriented industrialization enabled especially fast growth: producers of simple manufactures - toys, garments, electronics assembly - could expand almost without limit by absorbing technology from the advanced countries and cheap labor from the countryside. Export-oriented manufacturing served as a powerful growth escalator as long as production techniques were intensive in the most abundant factor of production in low-income countries: unskilled labor.

Manufacturing has experienced rapid technological progress in recent decades. Crucially, the improvement in technology has taken a particular form: it has been skill- and capital-biased. The share of low-skill labor in manufacturing value added has steadily fallen. Figures 6.2 and 6.3 (taken from Rodrik, 2016) portray the consequences globally. First, employment in manufacturing as a share of employment has come down steeply since the 1960s, once one controls for other determinants of industrialization levels such as income levels and demography. This is true both for countries with strong 
comparative advantage in manufacturing and for others, though the decline is smaller in the former. By the 2000s, the employment shortfall in manufacturing, taking the 1950s as the baseline, amounted to 9 percent of total employment in the first group of countries, and a whopping 12 percent in the second (Figure 6.2). Rodrik (2016) has called this "premature de-industrialization."

For a smaller sample of countries (and for a shorter period time), it is possible to decompose the "missing" manufacturing employment into three skill categories: high-skilled labor, medium-skilled labor, and low-skilled labor. As Figure 6.3 shows, the decline in employment is concentrated entirely in the low-skilled category. Kunst (2019) has also shown that premature de-industrialization has taken place mostly in low-skilled occupations.

Not surprisingly, in light of these trends, there has been a correspondingly sharp drop in the labor content of exports globally. A World Bank study reports that both the direct and indirect employment magnitudes created per dollar of exports have halved between 1997 and 2011 in a sample of 30+ countries (Cali et al., 2016, Table 3). While these results cover all exports, they are consistent with the implications of labor-saving technological change in manufacturing.

Since the bulk of technological innovation takes place in the advanced countries where factor proportions favor automation and skills, the direction that technological change has taken is not surprising. Producers in developed countries have tried to save on labor costs, especially as competition from low-wage exporters became more intense. But for developing countries, who are technology importers, the consequences are hardly salutary. Even if the new technologies disseminate rapidly and poor nations can easily acquire them, the declining low-skill intensity of manufacturing implies a reduction in comparative advantage in simple manufactures, less labor absorption by manufacturing, and lower growth possibilities. In the next subsection we illustrate this with a simple model.

\subsection{The simple analytics of technology choice}

To analyze the implications of biased technological innovation on employment in laborabundant countries, we consider a representative African firm with access initially to two kinds of technologies, a labor-intensive technology and a capital-intensive technology. The firm operates in an open economy, where the price of output, $p_{0}$, is exogenous and determined on world markets. In Figure 6.4, we show the unit costs of the two technologies and how they change with scale of production. As drawn, production with the labor-intensive technology results in lower unit costs (than production with the capital-intensive technology) over the relevant range of output. This is a natural consequence of 
lower labor costs in the African country. Firms in the country would choose to employ the laborintensive technology, and facing price $p_{0}$, produce an output $q_{0}$.

Note that the shapes of the two cost curves imply costs rise more rapidly under the capitalintensive technology. This is also a likely consequence of economic conditions in African countries. Labor can be drawn from the countryside or from informal activities without a steep rise in wages. Capital, on the one hand is scarce. Equally important, we can interpret capital more broadly here, as including other production inputs that are likely to be strong complements to capital in manufacturing - skilled labor and infrastructure in particular. ${ }^{18}$ Those are also likely to be comparatively scarce in a low-income country, which would contribute to the steepness of the cost curve for the capital-intensive technology.

We now consider the implications of a significant improvement in technology that affects only the capital-intensive mode of production. This is an extreme form of biased technological change that will simplify the exposition and help us make the argument. We assume this innovation takes form in the advanced countries, but the resulting technological advance is also available to the African country.

The innovation affects the diagram in two ways. First, the price on world markets falls as rich countries - using the capital-intensive technology - experience a reduction in costs, which is in turn passed on to world prices. This is shown in the figure by a reduction from $p_{0}$ to $p_{1}$.

Second, the relevant cost curve for the capital-intensive technology shifts down. As drawn, the vertical shift of the cost curve is less than the fall in prices. The rationale is the following. First, we assume all the cost savings in rich countries are passed on (at least on impact) to prices. Second, we assume (realistically) that capital costs are higher in the African country so that the cost benefits of the new technology are lower than on the rich countries. These imply that the reduction in African costs (with the new technology) is less than the drop in world prices.

Note that at the new level of prices, the labor-intensive technology is no longer cost-effective. The African firm will now shift to the capital-intensive technology. But the result is a fall in its level of

\footnotetext{
${ }^{18}$ Workers even in low-skill intensive manufacturing in Ethiopia tend to be more educated than the national average: "Despite low skilled manufacturing workers requiring only very limited training to be able to begin working, the workers in our sample are relatively educated, with $52.8 \%$ having completed at least year 10 and another $17.4 \%$ having additionally completed a technical and vocational training (TVET) course. Only $16.2 \%$ have not completed primary school. This is in contrast with average national statistics, which show that (primary) grade8 completion rate was 54\% in 2015/16 and gross enrolment rate in secondary education barely reached $30 \%$ " (Schaefer and Oya, 2019, p.23). And even in the textiles and garments sector, Ethiopian firms report that "skill shortages" are a key constraint (Abebe et al., 2019).
} 
production from $q_{0}$ to $q_{1}$. Even with full and costless access to the new technology, the African firm is disadvantaged. Moreover, the adverse employment impact is even larger than the output effect, since production now takes place using a more capital-intensive technology.

The framework highlights the double whammy of technological change that is biased towards capital. First, the African economy loses comparative advantage in manufacturing (or its comparative disadvantage becomes worse). Second, because of the induced shift to more capital-intensive technologies, there is a magnified adverse effect on employment.

Moreover, once firms have adopted the capital-intensive technology, the ability of the economy to increase manufacturing output (and generate employment) in response to new opportunities is reduced. That is because the cost curve of the new technology is steeper: due to scarcity of capital and complementary inputs (skills, infrastructure) any potential expansion of employment and output is choked off by rising costs. Not only is the comparative advantage of the economy in manufactures undermined, its supply curve is less responsive to higher prices (or lower costs). This helps explain the inability of African manufacturing to scale up.

\subsection{Appropriate and inappropriate technologies}

Our interpretation of the evidence harks back to an earlier debate in the development literature on appropriate technology for low-income nations. As popularized by E.F. Schumacher's (1973) book "Small is Beautiful," one important strand of argument held that the technologies developed in advanced countries were not suitable to low-income countries because they were excessively capital intensive and needed to be operated at large scale. Transfer of existing technologies would not foster development; it may even hamper it. An even earlier argument along similar lines was set out by Eckaus (1955) using a neoclassical framework, based on limited substitutability between labor and capital in the production function (our discussion above is in line with the Eckaus model). These arguments have largely gone out of fashion, with some exceptions (e.g. Basu and Weil, 1998). Even non-neoclassical economists have tended to underplay the importance of the Eckaus-Schumacher argument. In a recent paper, for example, Kaplinsky (2011) suggests the dissemination of innovation capacity among developing nations can foster intermediate technologies more appropriate to low-income settings.

Nevertheless, it is clear that economizing on labor has been the main thrust behind technological innovation in manufacturing. Production methods have become increasingly capital- and skill-intensive. Moreover, the spread of global value chains (GVCs) and increased openness to trade have 
had the effect of homogenizing technology around the world (Rodrik 2018). Plugging into GVCs requires producing to rich-country firms' standards, and that typically means using their technology. ${ }^{19}$

A similar process has been taking place in production for the home market as well. Not so long ago, a combination of natural and man-made protection - transport costs and import restrictions - left space for domestically oriented firms to serve home consumers with lower quality products produced with labor-intensive techniques. As international competition has intensified, such market segmentation has become more difficult, reinforcing the globally homogenizing trend in manufacturing technologies. Sen (2019) reports that trade integration reduces the employment intensity of manufacturing production in developing countries. Pahl (2020) finds that participation in GVCs tend to increase labor productivity but not employment.

\section{Concluding remarks}

Covid-19 has unsettled the world economy in many ways, creating a significant setback for the development prospects of low-income countries. Even after the immediate crisis dissipates, slower expansion of world trade and a general trend towards reshoring of supply chains may make it difficult for these countries to fully reap the gains from the global division of labor. Our results provide cause for concern of a different sort.

Our analysis of the manufacturing sectors in Ethiopia and Tanzania reveals a dichotomy between larger firms that exhibit superior productivity performance but do not expand employment much, and small firms that absorb employment but do not experience much productivity growth. Typically, economic development happens when the productively dynamic parts of the economy absorb resources from the rest. By contrast, the choice that African manufacturers seem to face is either to increase productivity or to increase employment.

\footnotetext{
${ }^{19}$ A World Bank report (Farole, 2016) divided exports into two types of goods, called "GVC products" and "nonGVC products" and regressed an export performance index for each group on a number of country characteristics, including proximity to major markets, natural resources, human and physical capital, institutional quality, logistics/connectivity, and wage competitiveness. For non-GVC products, wage competitiveness was the only item on the list that significantly correlated with export performance. For GVC products, by contrast, all of the factors strongly correlated with export performance - with the glaring exception of wage competitiveness (Farole, 2016, p. 34). It appears GVCs demand skills and capabilities that are in short supply in developing countries, and undercut their traditional comparative advantage in unskilled labor.
} 
We doubt that this pattern can be explained (only) by factor-price distortions or other institutional shortcomings specific to the African setting. Our interpretation is that the technologies available on world markets restrict the range of production techniques that can be used by firms. As the capital- (and skill-) intensity of global technology has increased, the gap with low-income countries' factor endowments has opened very wide. Becoming more productive requires adopting technologies with factor input combinations that are increasingly at variance with African countries' factor abundance.

From the standpoint of trade theory, our interpretation amounts to an argument that Ethiopia and Tanzania have been losing comparative advantage in traditionally labor-intensive manufactures due to a trend reduction in their labor intensity. This implies a loss in the gains from trade. It also lowers the ceiling on industrialization and constrains the capacity of manufacturing to absorb labor productively.

This is not to say that manufacturing cannot play an important role in in the development of these countries. After all, productivity growth in the large manufacturing firms in Tanzania and Ethiopia has been impressive and could create jobs indirectly. For example, while the manufacturing of food products is capital intensive, smallholder farming is labor intensive. Worker training programs associated with industrialization strategies like Ethiopia's Technical and Vocational Education and Training School (TVET) could also enhance the capabilities of smaller firms. And the managerial and logistical capabilities of large manufacturing firms could be transferred to other activities through worker turnover or informal networks (Abebe et al, 2018). But tempering expectations is important especially in politically fragile countries like Ethiopia. 


\section{Appendix 1: Calculation of capital-labor ratios}

We use firm level data for Ethiopia and Tanzania, restricting our analysis to firms in the sample for at least two years which allows us to check for coding errors and outliers. We define the capital stock as machinery and equipment (excluding transport and ICT equipment) and buildings and structures (excluding dwellings) in constant value; we compute each of these measures separately and then combine them so that we can apply the appropriate deflators.

We begin by converting end of year values from current local currency units to constant 2010 local currency units. We use a deflator of one for machinery and equipment and each country's GDP deflator for buildings. ${ }^{20}$ The capital stocks in constant 2010 local currency units are then converted to constant 2010 US dollar using 2010 official market exchange rates. Finally, capital stocks are converted to 2010 Purchasing Power Parities (PPPs) using ICP price deflators available at https://www.worldbank.org/en/programs/icp (International Comparison Program) (World Bank 2020b).

The PPP exchange rates for "Machinery and Equipment" and "Construction" are used in the conversion for each of the two types of capital. The 2010 PPP exchange rates are derived from the annual growth rate in the PPP exchange rates between 2011 and 2017, which are available in ICP database. The PPP exchange rates for machinery and equipment are consistently higher than the PPP exchange rates for construction in most countries; the difference is particularly large for low-income countries. In the cases of Ethiopia and Tanzania, the ratio of the PPP value of machinery and equipment to construction is 7.99 for Ethiopia and for Tanzania it is 8.23. Moreover, the 2011 PPP exchange rates for machinery and equipment are $30 \%$ and $20 \%$ higher than the market exchange rates in Ethiopia and Tanzania respectively. By contrast, the PPP exchange rates for construction are only $17 \%$ and $14 \%$ of market exchange rates in these two countries respectively.

For employment, we use the number of permanent persons employed. However, data in Tanzania's ASIP does not separate permanent and temporary employment, thus we use total persons

\footnotetext{
${ }^{20}$ We use a deflator of one for machinery and equipment based on the price indices for the comparable EU countries in the KLEMS database. Values of price indices for other machinery and equipment stock (i.e., machinery and equipment excluding transport and ICT equipment) are very close to 100 , the value for the base year 2010, for all years for most countries in the database. Taking Czech Republic as an example. In the 23 years between 1995 and 2017, there are only seven years (1999-2001 prior 2010 and 2014-2017 post 2010) where the index value is higher than 110 but the highest value is only 114 in 2016, while it is close to 100 for the remaining 16 years. As a robustness test, we also use index value of gross capital formation as a deflator for both machinery and equipment and buildings and structures. The results are similar; see Figure A.3.
} 
employed, which could cause us to underestimate capital intensity in Tanzania compared with Ethiopia and the comparable EU countries. ${ }^{21}$

We divide the total capital stock - equal to the sum of the capital stock in machinery and equipment plus buildings - by the number of employees to get the capital-labor ratio for each year and then take the average over different periods. For the most recent period, it is 2010-2017 for Ethiopia and 2010-2016 for Tanzania since 2017 data are not available for Tanzania.

As in our other analyses, we define firm size in the following way: firms with 10-49 employees are classified as small firms while firms with 50 or more employees are classified as large firms. However, we create new, time-invariant definitions for foreign and exporting firms in order to create aggregates from a consistent sample of firms. Foreign firms are defined as those with foreign ownership for the majority of years or at least one year with data available only for two years. Exporters are firms reporting exports in every year.

Among the large firms, we further classify firms by capital intensity in the following way. First, we rank firms by capital - labor ratio $(\mathrm{K} / \mathrm{L})$ and then choose the top $10 \%$ firms according to $\mathrm{K} / \mathrm{L}$ for the initial year of each panel (1996 for Ethiopia and 2008 for Tanzania). In the next year, we add to these new firms according to their $\mathrm{K} / \mathrm{L}$ ratio in the same way. Thus, once a firm is classified as in the top $10 \%$ according to capital intensity, it remains in that group for every year it is observed. We follow the same procedure to classify the bottom $10 \%$ of firms, and the middle $80 \%$ is defined as the residual. Among the large firms, we further classify firms that enter the sample in 2010 or later as new entrants relative to firms that are in the sample prior to 2010.

In addition to reporting $\mathrm{K} / \mathrm{L}$ ratios for the full sample, we also report $\mathrm{K} / \mathrm{L}$ ratios for the following sector groups: (a) food products, beverages and tobacco; (b) rubber and plastics and non-metallic minerals, and; (c) textiles, wearing apparel, leather and related products. These groups are comparable to the sector grouping in the EU-KLEMS database.

We chose these sectors because of their relative importance to Ethiopia and Tanzania. Measured by value-added, food products, beverages and tobacco is the largest sector in both countries $-41 \%$ of total manufacturing value-added in Ethiopia and 56\% in Tanzania. Rubber and plastics

\footnotetext{
${ }^{21}$ The KLEMS database also includes persons employed in hours. The ratios between persons employed in hours and persons employed indicate that the KLEMS data is reporting permanent persons employed (or the full time equivalent of persons employed.)
} 
products, and other non-metallic mineral products sector is also relatively large in both countries - $17 \%$ of total manufacturing value-added in Ethiopia and $16 \%$ in Tanzania. Textiles, wearing apparel, leather and related products, a less capital-intensive sector, accounts for $10 \%$ of total manufacturing valueadded in Ethiopia and 4\% in Tanzania.

Finally, in Tables A.2-A.3, we report 2010-2017 average K/L ratios in thousands of 2010 constant USD and PPP for Ethiopia and Tanzania plus six EU countries for total manufacturing and three manufacturing sectors respectively. The conversion of the ratios for the six EU countries follows the same procedure used for Ethiopia and Tanzania described above. Four of the six EU countries are lower income than the richest EU countries and have sizable populations and manufacturing sectors. The remaining two countries - the Netherlands and the UK - are high income countries and among the largest foreign investors in Africa. 


\section{References}

Abebe, G., McMillan, M.S. and Serafinelli, M., 2018. Foreign direct investment and knowledge diffusion in poor locations: Evidence from Ethiopia (No. w24461). National Bureau of Economic Research.

Abebe, G., T.G. Tekleselassie, and J. Haji, 2019. Skills for Trade and Economic Diversification in Ethiopia: A Background Paper for the Drafting of a Sector Skills Strategy for the Garment Sector in Ethiopia, August.

Badiane, O., Diao, X., Jayne, T.S., Otsuka, K. and Fan, S., (forthcoming). Africa's unfolding agricultural transformation. Agricultural development: New perspectives in a changing world. Unpublished book manuscript

Basu, S. and Weil, D.N., 1998. Appropriate technology and growth. The Quarterly Journal of Economics, 113(4), pp.1025-1054.

Blattman, C. and Dercon, S., 2018. The impacts of industrial and entrepreneurial work on income and health: Experimental evidence from Ethiopia. American Economic Journal: Applied Economics, 10(3), pp.1-38.

Bourguignon, F. and Wangwe, S., 2018. AN INSTITUTIONAL DIAGNOSTIC OF TANZANIA: SYNTHESIS.

Calì, M., Francois, J., Hollweg, C.H., Manchin, M., Oberdabernig, D.A., Rojas-Romagosa, H., Rubinova, S. and Tomberger, P., 2016. The labor content of exports database. The World Bank.

CSA (Central Statistical Agency), 2001. Report on Large and Medium Scale Manufacturing and Electricity Industries Survey, 2000-2001, Addis Ababa, Ethiopia, February 2001.

2003. Report on Small Scale Manufacturing Industry Survey 2002, Addis Ababa, Ethiopia, September 2003. https://www.statsethiopia.gov.et/wpcontent/uploads/2019/06/Small-Scale-Manufacturing-Survey-Report-2002.pdf

2004. Report on Large and Medium Scale Manufacturing and Electricity Industries Survey, 2003-2004, Addis Ababa, Ethiopia, November 2004.

2006. Report on Small Scale Manufacturing Industry Survey 2006, Addis Ababa, Ethiopia, December 2006. https://www.statsethiopia.gov.et/wpcontent/uploads/2019/06/Small-Scale-Manufacturing-Survey-Report-2006.pdf 2008. Report on Large and Medium Scale Manufacturing and Electricity Industries Survey, 2007-2008, Addis Ababa, Ethiopia, November 2008.

2010a. Report on Small Scale Manufacturing Industry Survey 2008, Addis Ababa, Ethiopia, April 2010. https://www.statsethiopia.gov.et/wp-content/uploads/2019/06/SmallScale-Manufacturing-Survey-Report-2008.pdf 
2010b. Report on Small Scale Manufacturing Industry Survey 2010, Addis Ababa, Ethiopia, 2010. https://www.statsethiopia.gov.et/wp-content/uploads/2019/06/Small-ScaleManufacturing-Survey-Report-2010.pdf

2011a. Large and Medium Scale Manufacturing and Electricity Industries Survey, 1999-2000, Study Documentation, Addis Ababa, Ethiopia, January 2011.

2011b. Large and Medium Scale Manufacturing and Electricity Industries Survey, 2002-2003, Study Documentation, Addis Ababa, Ethiopia, January 2011.

,2011c. Report on Large and Medium Scale Manufacturing and Electricity Industries Survey, 2009-2010, Addis Ababa, Ethiopia, August 2011.

2014. Report on Small Scale Manufacturing Industry Survey 2014, Addis Ababa, Ethiopia, 2014. https://www.statsethiopia.gov.et/wp-content/uploads/2019/06/Small-ScaleManufacturing-Survey-Report-2014.pdf

Diao, X., McMillan, M. and Rodrik, D., 2019. The recent growth boom in developing economies: A structural-change perspective. In The Palgrave Handbook of Development Economics (pp. 281334). Palgrave Macmillan, Cham.

Eckaus, R.S., 1955. The factor proportions problem in underdeveloped areas. The American Economic Review, 45(4), pp.539-565.

Ethiopian Investment Commission (EIC), 2019. Unpublished statistics on exports and employment in Ethiopia's industrial parks, Addis Ababa, Ethiopia

Farole, T., 2016. Factory Southern Africa?: SACU in global value chains-summary report (No. 102850, pp. 1-110). The World Bank.

Gelb, A., Ramachandran, V., Meyer, C.J., Wadhwa, D. and Navis, K., 2020. Can Sub-Saharan Africa be a manufacturing destination? Labor costs, price levels, and the role of industrial policy. Journal of Industry, Competition and Trade, pp.1-23.

Haltiwanger, J., Jarmin, R.S. and Miranda, J., 2013. Who creates jobs? Small versus large versus young. Review of Economics and Statistics, 95(2), pp.347-361.

Hsieh, C.T. and Olken, B.A., 2014. The missing" missing middle". Journal of Economic Perspectives, 28(3), pp.89-108.

Huang, S.W., 1993. Structural change in Taiwan's agricultural economy. Economic Development and Cultural Change, 42(1), pp.43-65.

Kaplinsky, R., 2011. Schumacher meets Schumpeter: Appropriate technology below the radar. Research Policy, 40(2), pp.193-203. 
Kunst, D., 2019. Premature Deindustrialization through the Lens of Occupations: Which Jobs, Why, and Where? Tinbergen Institute Discussion Paper, No. TI 2019-033/V, Tinbergen Institute, Amsterdam and Rotterdam.

Martin, L.A., Nataraj, S. and Harrison, A.E., 2017. In with the big, out with the small: Removing smallscale reservations in India. American Economic Review, 107(2), pp.354-86.

McCaig, B. and Pavcnik, N., 2017. Moving out of agriculture: structural change in Vietnam, Chapter 2 in McMillan, M., Rodrik, D. and Sepulveda, C. (Eds.), Structural change, fundamentals, and growth: A framework and case studies. Washington, D.C.: International Food Policy Research Institute (IFPRI). http://dx.doi.org/10.2499/9780896292147

McCaig, B., Pavcnik, N. and Wong, W.F., 2020. FDI Inflows and Domestic Firms: Adjustments to New Export Opportunities. https://www.freit.org/EIIT/2020/selected/wong.pdf

Mensah, E. B; Owusu, S; Foster-McGregor, N; and Szirmai, A., 2018. Structural Change, Productivity Growth and Labor Market Turbulence in Africa. Forthcoming, Journal of African Economies.

NBS (National Bureau of Statistics), 2009. National Panel Survey 2008-2009, Wave 1. The United Republic of Tanzania, National Bureau of Statistics. Downloaded from http://microdata.worldbank.org in August 2020

2010a. Annual Survey of Industrial Production and Performance, 2008: Analytic Report. The United Republic of Tanzania, Ministry of Industry, Trade and Marketing, National Bureau of Statistics, and Confederation of Tanzania Industries, September 2010.

2010b. Annual Survey of Industrial Production and Performance, 2008: Statistical Report. The United Republic of Tanzania, Ministry of Industry, Trade and Marketing, National Bureau of Statistics, and Confederation of Tanzania Industries, September 2010.

2011. National Panel Survey Report 2010-2011, Wave 2. The United Republic of Tanzania, National Bureau of Statistics. Downloaded from http://microdata.worldbank.org in August 2020

2012. Annual Survey of Industrial Production, 2009: Statistical Report. The United Republic of Tanzania, Ministry of Industry, Trade and Marketing, National Bureau of Statistics, and Confederation of Tanzania Industries, May 2012.

2013. National Panel Survey Report 2012-2013, Wave 3. The United Republic of Tanzania, National Bureau of Statistics. Downloaded from http://microdata.worldbank.org in August 2020

2015. National Panel Survey 2015-2014, Wave 4. The United Republic of Tanzania, National Bureau of Statistics. Downloaded from http://microdata.worldbank.org in August 2020 
2016a. Census of Industrial Production, 2013: Analytic Report. The United Republic of

Tanzania, National Bureau of Statistics and Ministry of Industry, Trade and Investment, September 2016.

2016b. Census of Industrial Production, 2013: Statistical Report. The United Republic of Tanzania, National Bureau of Statistics and Ministry of Industry, Trade and Investment, September 2016.

2018a. Annual Survey of Industrial Production, 2015: Statistical Report. The United Republic of Tanzania, National Bureau of Statistics and Ministry of Industry, Trade and Investment, October 2018.

2018b. Annual Survey of Industrial Production, 2016: Statistical Report. The United Republic of Tanzania, National Bureau of Statistics and Ministry of Industry, Trade and Investment, October 2018.

Newman, C., Page, J., Rand, J., Shemeles, A., Söderbom, M. and Tarp, F., 2016. Made in Africa: Learning to compete in industry. Brookings Institution Press.

Oqubay, A., 2015. Made in Africa: industrial policy in Ethiopia. Oxford University Press, USA.

Oqubay, A., 2018. The structure and performance of the Ethiopian manufacturing sector. In The Oxford Handbook of the Ethiopian Economy.

Rodrik, D., 2013. Unconditional convergence in manufacturing. The Quarterly Journal of Economics, 128(1), pp.165-204.

Pahl, Stefan, 2020. Global Value Chains and Developing Countries. University of Groningen. PhD Thesis.

Rodrik, D., 2016. Premature deindustrialization. Journal of economic growth, 21(1), pp.1-33.

Rodrik, D., 2018. New technologies, global value chains, and developing economies (No. w25164). National Bureau of Economic Research.

Sala-i-Martin, X., 1996. Regional cohesion: evidence and theories of regional growth and convergence. European Economic Review, 40(6), pp.1325-1352.

Schaefer, F. and Oya, C., 2019. Employment Patterns and Conditions in Construction and Manufacturing in Ethiopia. IDCEA Research Report, SOAS, University of London

Sen, Kunal 2019. What Explains the Job Creating Potential of Industrialisation in the Developing World? The Journal of Development Studies, 55:7, 1565-1583.

Timmer, M., de Vries, G.J. and De Vries, K., 2015. Patterns of structural change in developing countries. In J. Weiss, \& M. Tribe (Eds.), Routledge Handbook of Industry and Development (pp. 79-97). Routledge. 
Schumacher, E.F., 1973. Small is Beautiful, Blond \& Briggs, London.

Stehrer, R., Bykova, A., Jäger, K., Reiter, O. and Schwarzhappel, M., 2019. Industry-level growth and productivity data with special focus on intangible assets: Report on methodologies and data construction for the EU KLEMS release 2019. The Vienna Institute for International Economic Studies.

UNIDO, 2020. INDSTAT 2 Industrial Statistics Database at 2-digit level of ISIC Revision 3. Vienna. Available from http://stat.unido.org

Wangwe, S. and Gray, H., 2018. POLITICS AND BUSINESS.

World Bank, 2020a. World Development Indicators (WDI). https://databank.worldbank.org/reports.aspx?source=World-Development-Indicators, last access in December 2020.

World Bank, 2020b. International Comparison Program (ICP). https://www.worldbank.org/en/programs/icp, last access in December 2020. 


\section{Tables \& Figures}

Figure 2.1: Labor productivity growth within agricultural and nonagricultural sectors and due to structural change (annual growth rates, percentages)

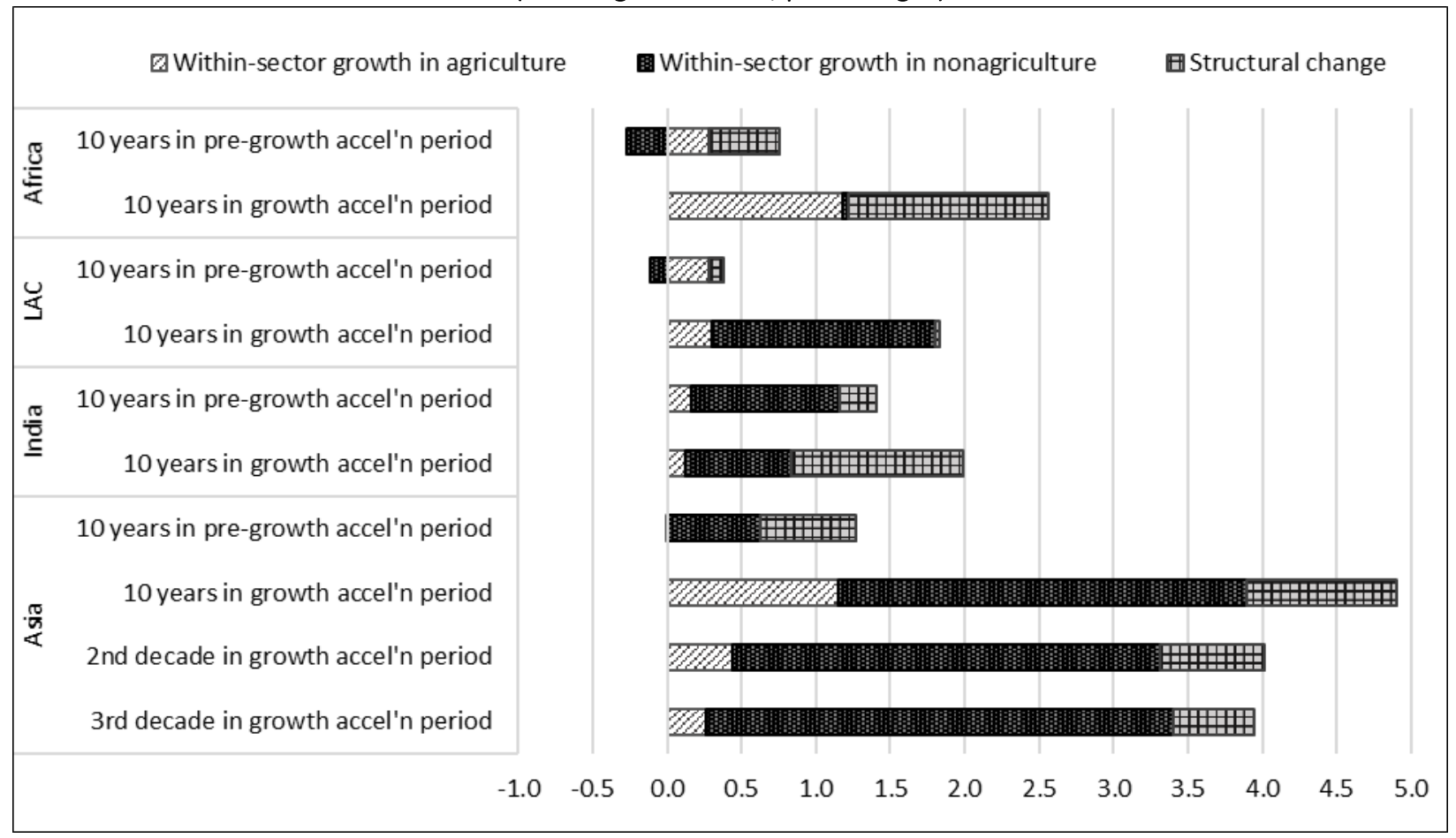

Source: Updated results include 18 African countries through 2015. Original results appeared in Diao, X., McMillan, M. and Rodrik, D., 2019. The recent growth boom in developing economies: A structuralchange perspective. In The Palgrave Handbook of Development Economics (pp. 281-334). Palgrave Macmillan, Cham. 
Figure 2.2a Negative correlation between labor productivity growth within selected nonagricultural sectors and from structural change in African countries

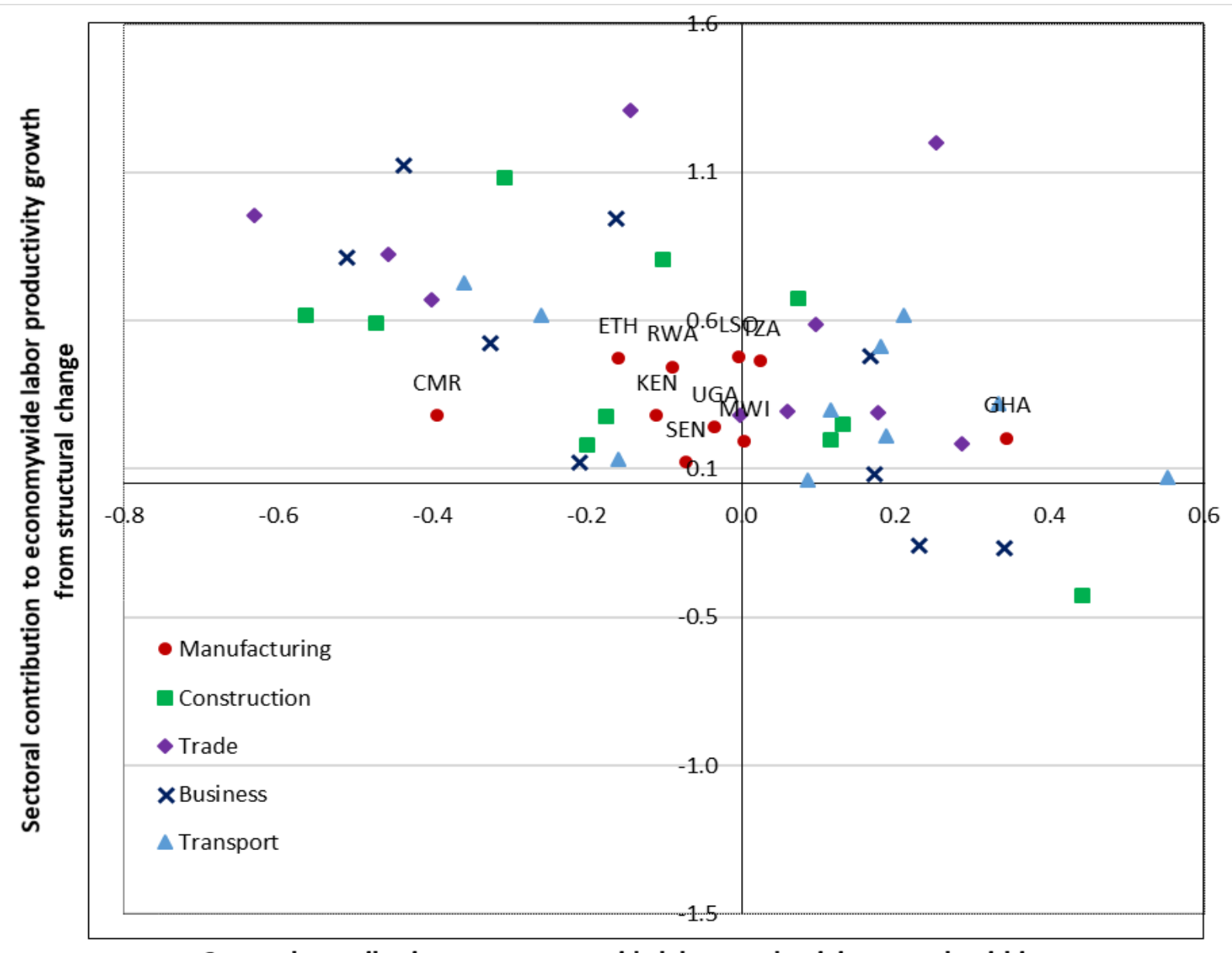

Sectoral contribution to economywide labor productivity growth within sector

Source: Updated results include 18 African countries through 2015. Original results appeared in Diao, X., McMillan, M. and Rodrik, D., 2019. 
Figure 2.2b Positive correlation between labor productivity growth within selected nonagricultural sectors and from structural change in Asian countries

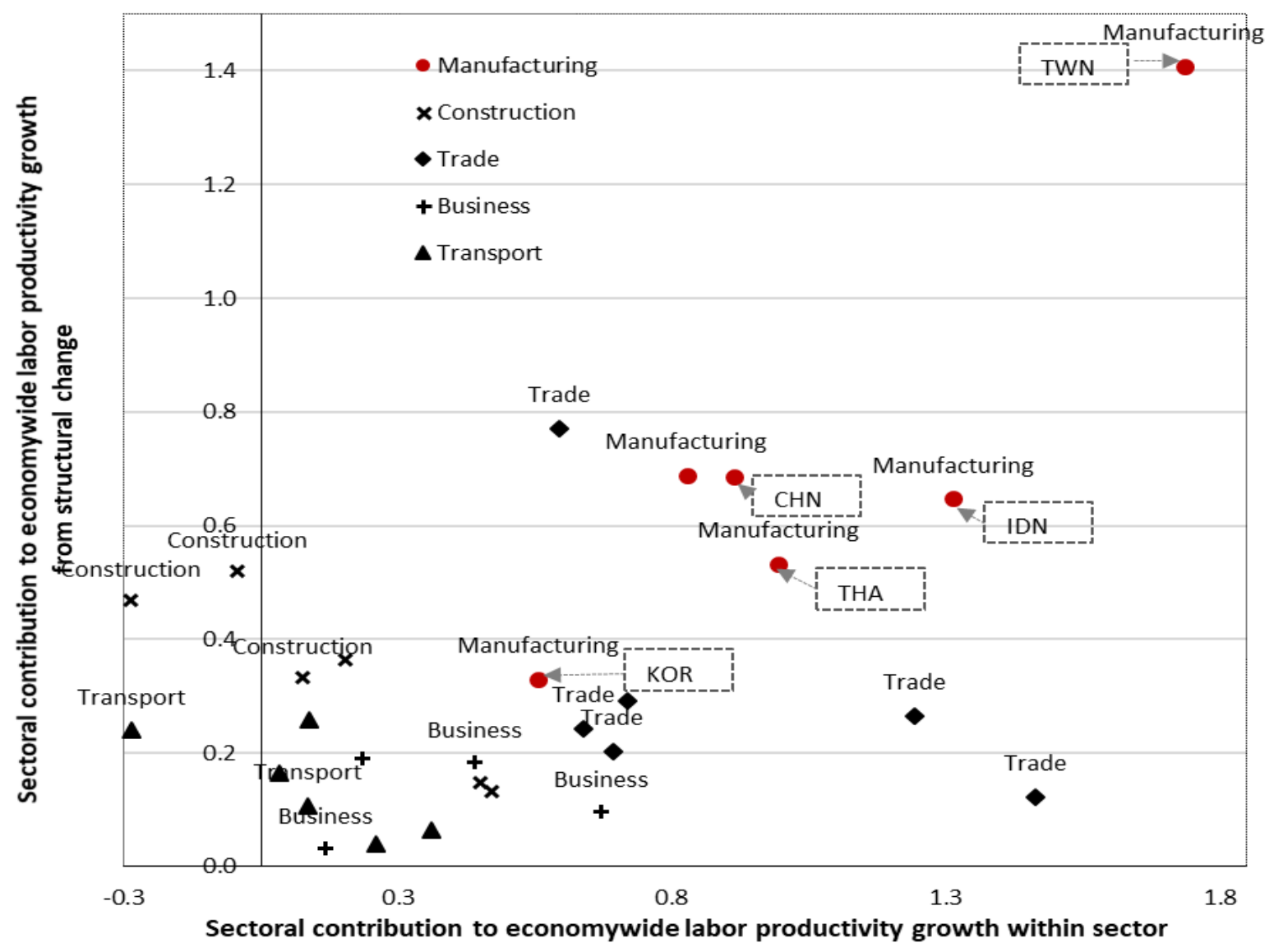

Source: Updated results include 18 African countries through 2015. Original results appeared in Diao, X., McMillan, M. and Rodrik, D., 2019. 
Figure 2.3a Total, formal, small and informal manufacturing employment in Tanzania and Ethiopia

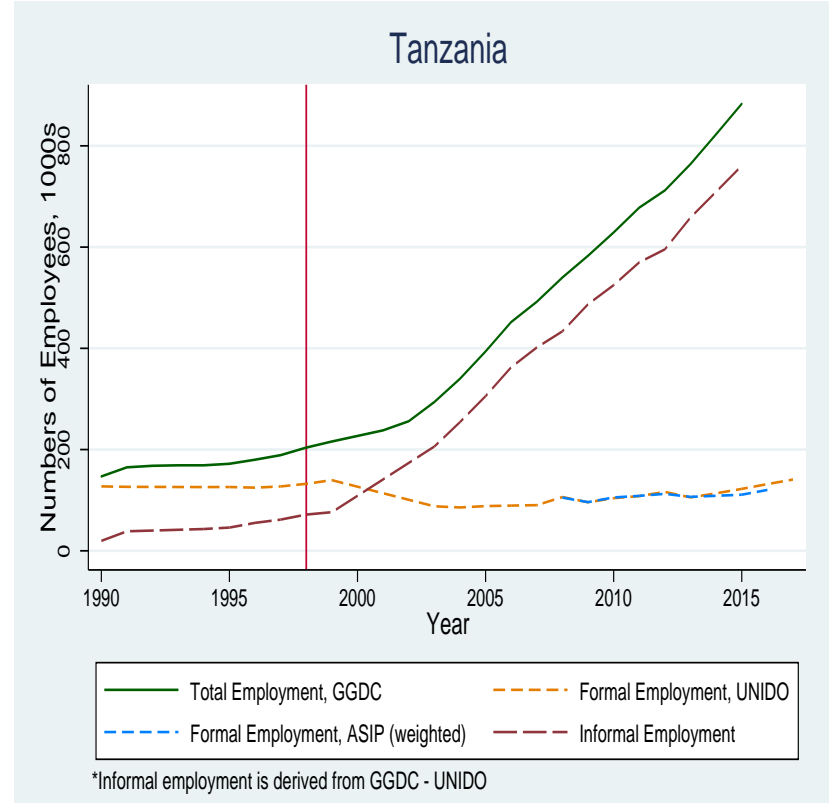

Note: The vertical red line indicates the start of the country's growth acceleration

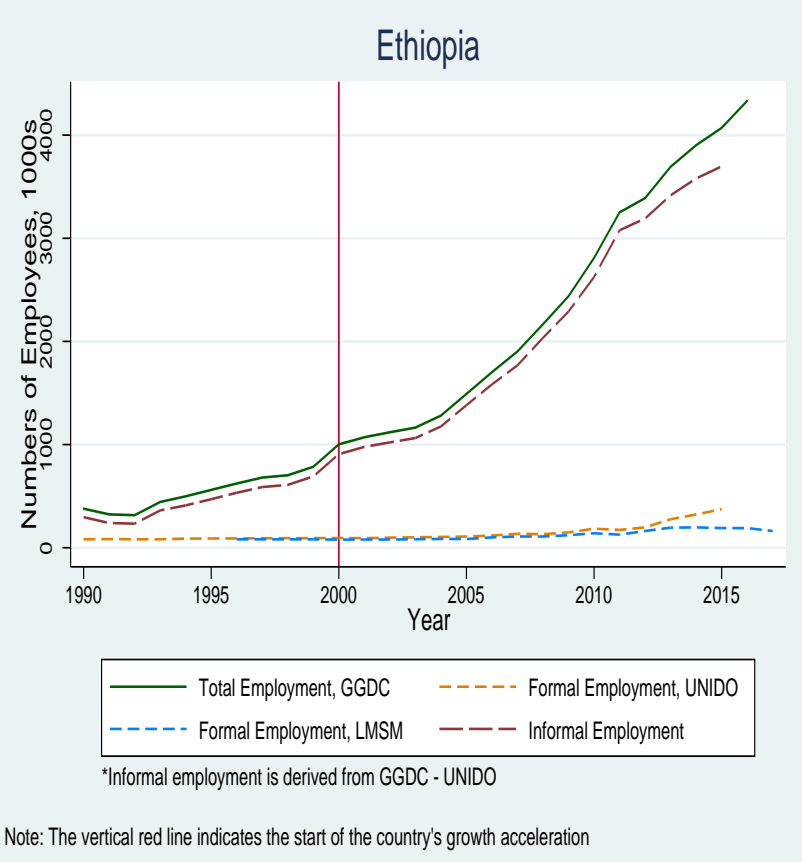

Figure 2.3b Total, formal, small and informal manufacturing employment in Taiwan and Vietnam

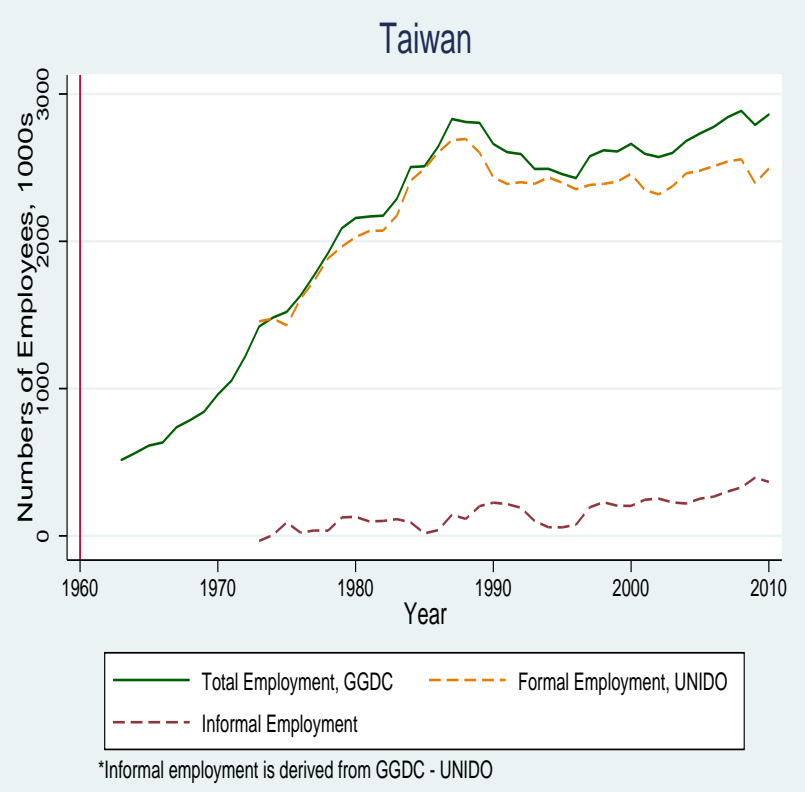

Note: The vertical red line indicates the start of the country's growth acceleration

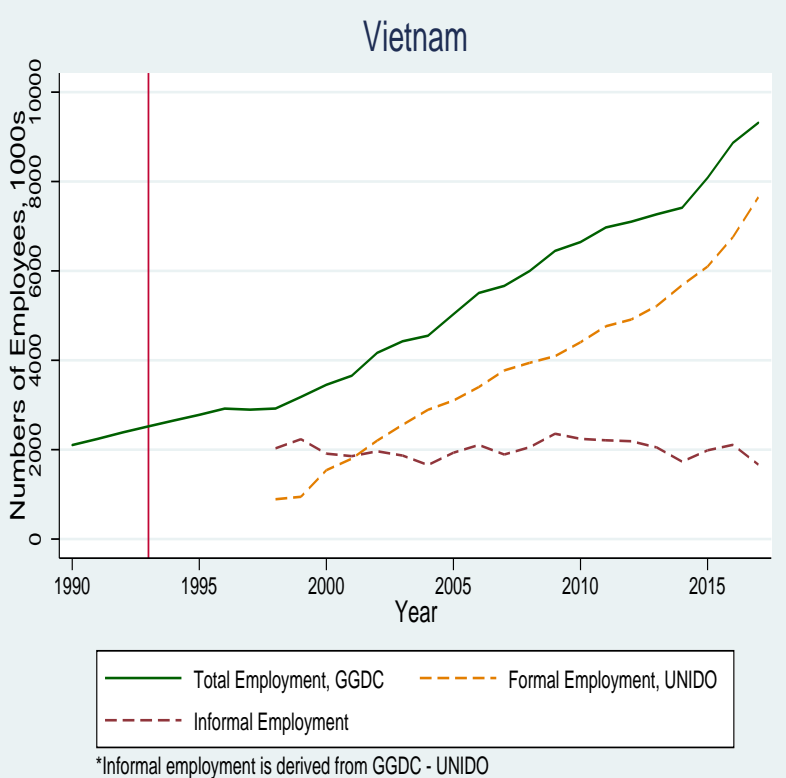

Note: The vertical red line indicates the start of the country's growth acceleration

Notes: Total manufacturing employment comes from the GGDC 10 sector database. Formal sector employment is based on UNIDO data and in the cases of Tanzania and Ethiopia, we also plot formal sector employment using aggregates from the firm level censuses for each country; these firms employ 10 or more workers. We label the difference between total and formal as small and informal firm employment. 
Figure 2.4: Agricultural labor productivity growth and informal manufacturing employment
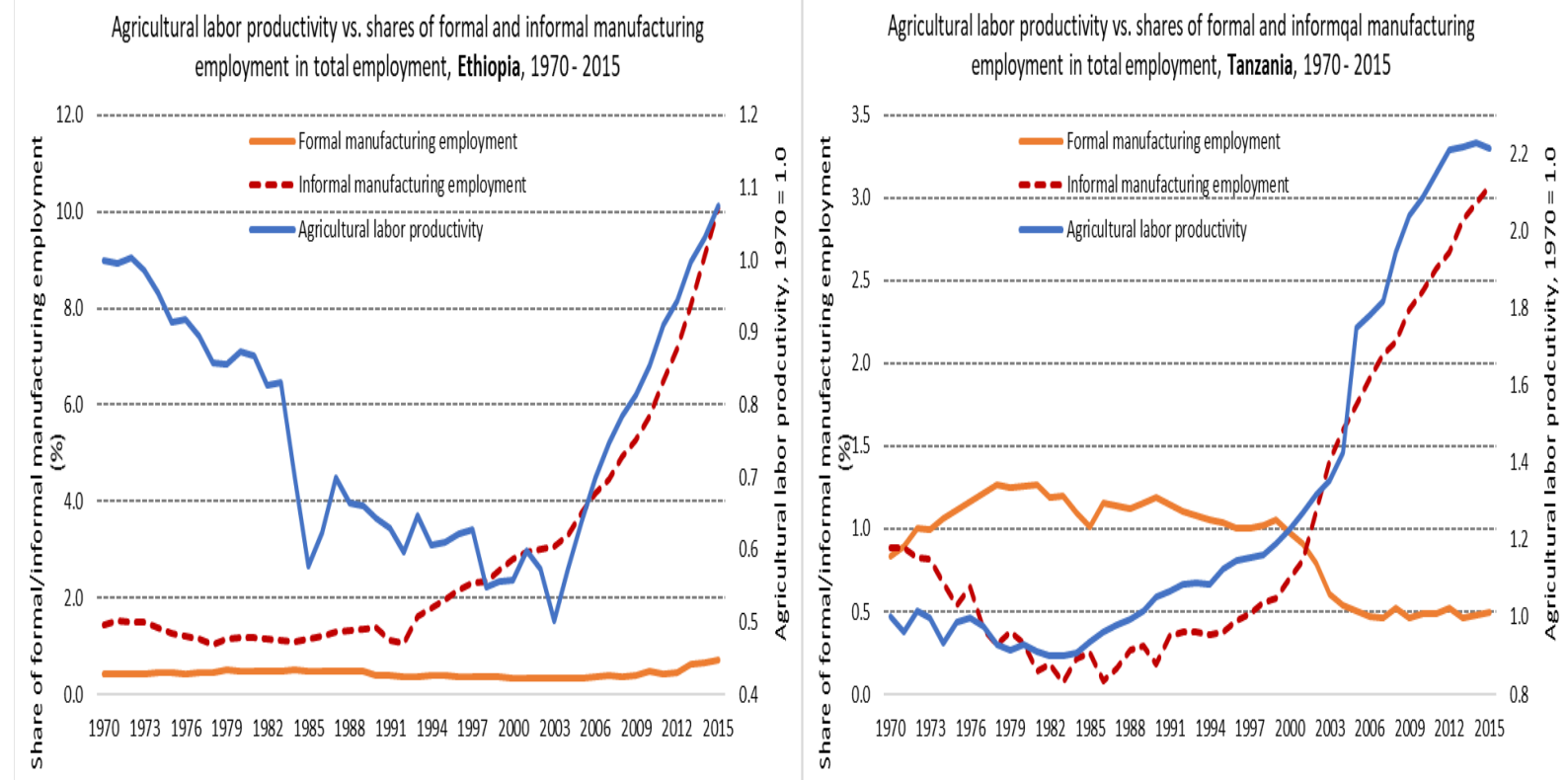

Notes: Formal manufacturing employment is based on UNIDO data and informal employment is the difference between total manufacturing employment of GGDC and UNIDO data for formal employment. Agricultural labor productivity is calculated using data from GGDC for agricultural value-added and employment. In the figure, agricultural labor productivity is an index with its value in $1970=1.0$. 
Figure 3.1: Distribution of firms in the Tanzania ASIP panel, 2008-2016

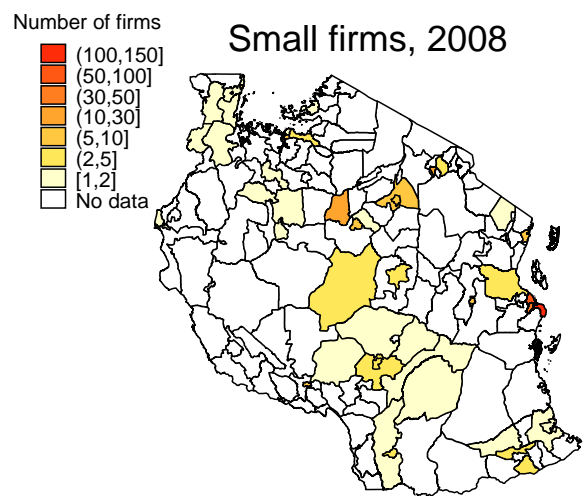

Large firms, 2008

Small firms, 2016
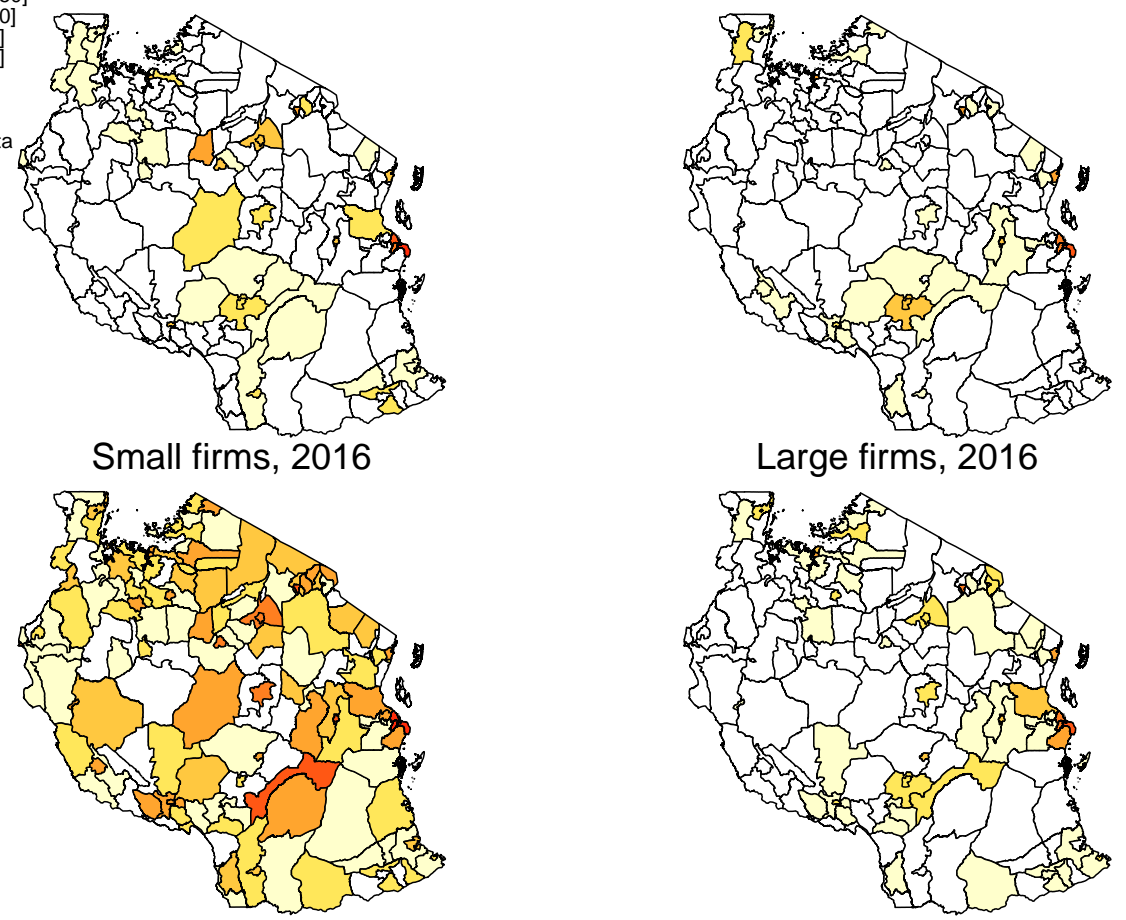

Large firms, 2016

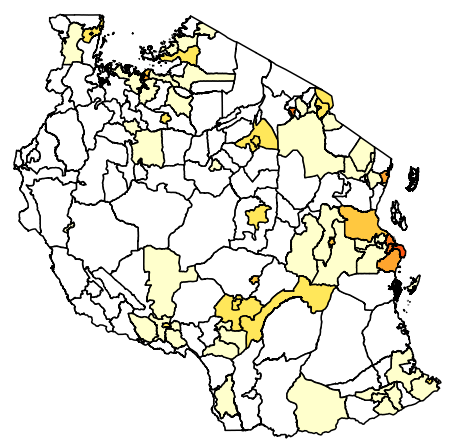

Notes: These are district-level maps, the second-largest administrative division after regions, created using the Annual Survey of Industrial Production (ASIP). Small firms are defined as having 10-49 workers, and large firms have 50 or more workers. 
Figure 3.2: Distribution of firms in the Ethiopia LMSM and SSI data, 2002-2014
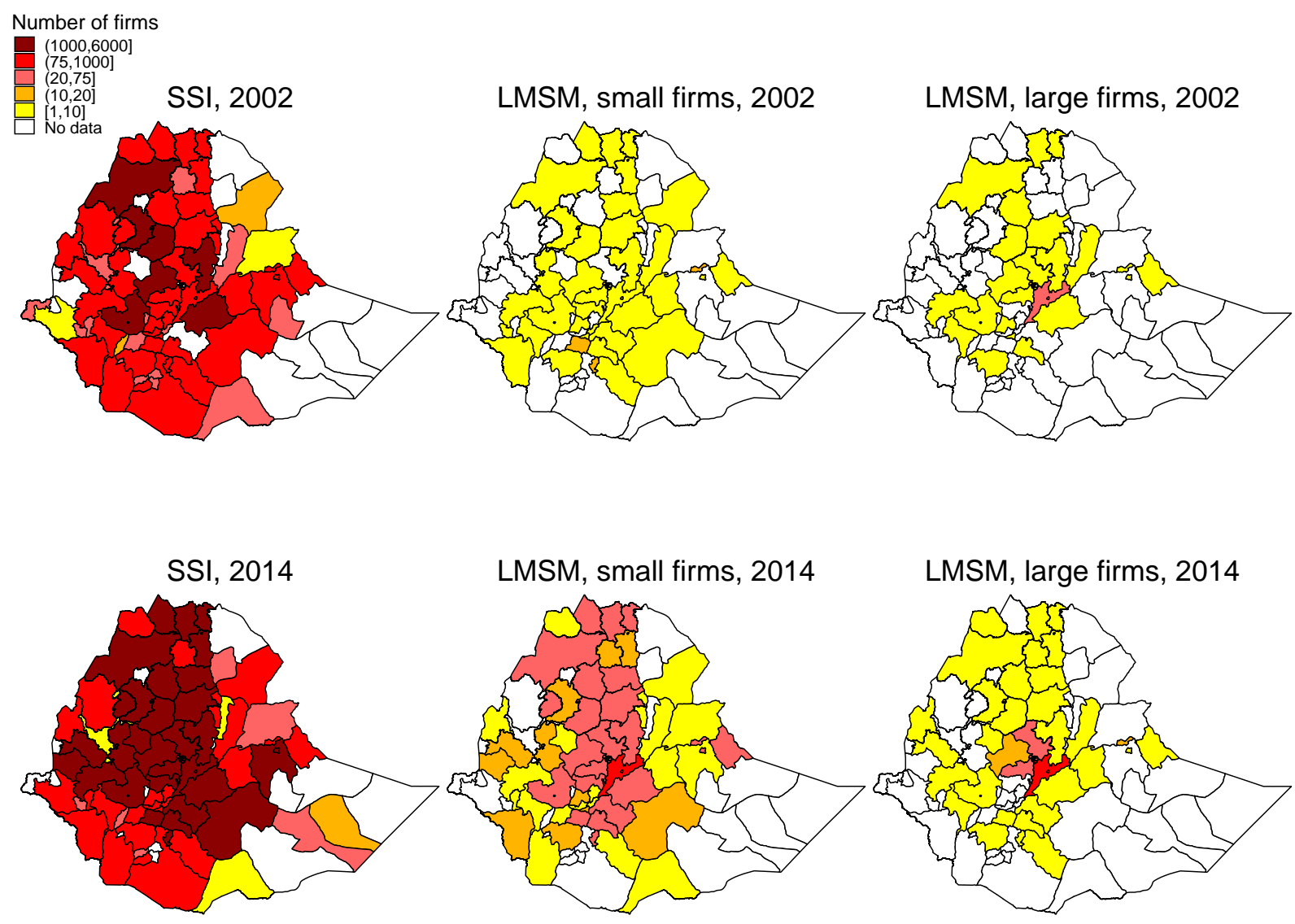

Notes: This map is at the zone level in Ethiopia. Data for firms with $<10$ employees come from the Small Scale Manufacturing Industries (SSI), while we use data from the Large and Medium Scale Manufacturing Industries (LMSM) for small firms with 10-49 employees and large firms with 50+ employees.

Source: Author's calculations using LMSM \& SSI data 
Figure 4.1: Tanzania estimated employment growth by firm size and age

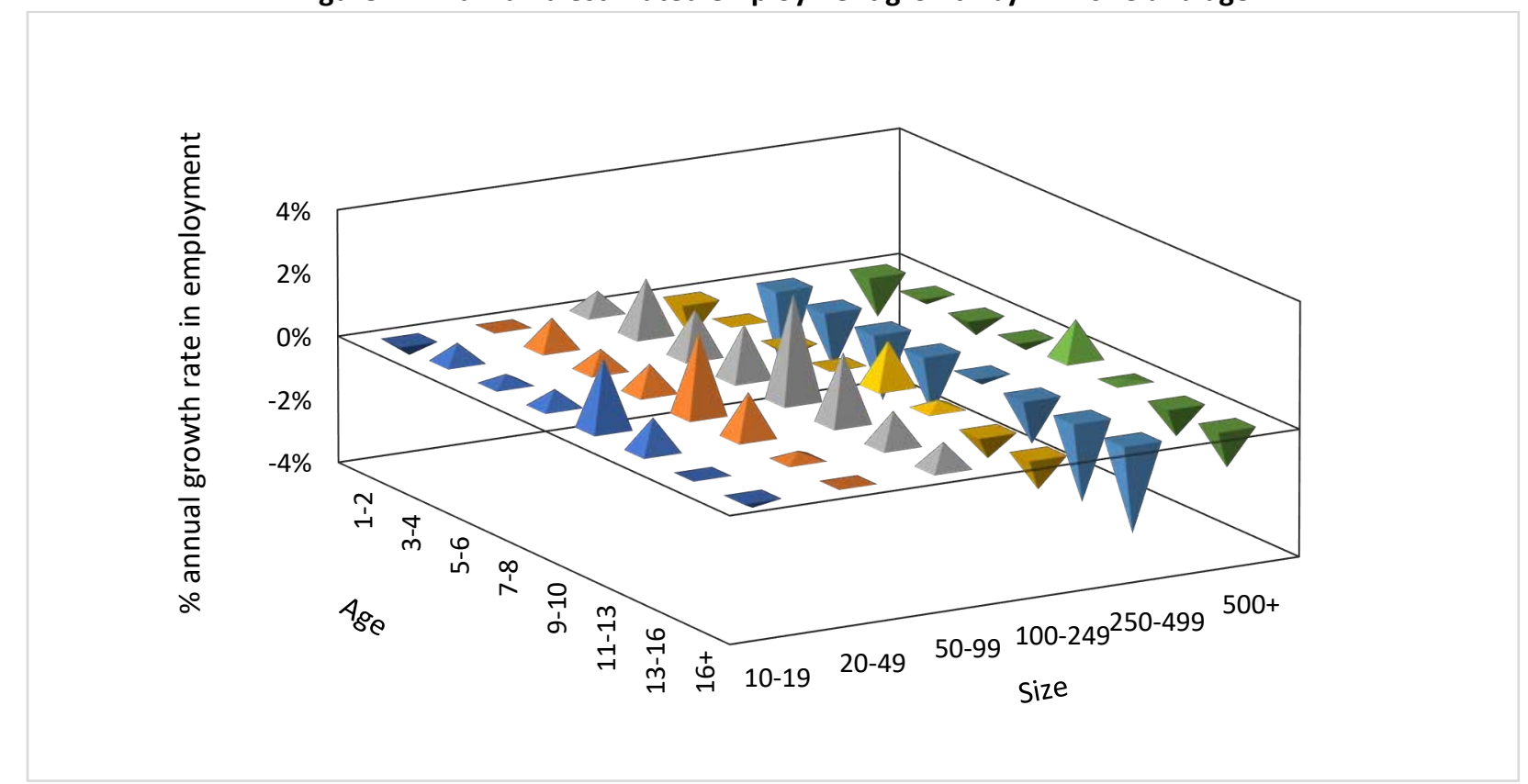

Notes: The coefficients plotted in this table come from regressions estimating the non-parametric relationship between employment growth and firm size and age groups. Firms are assigned to size and age groups based on the average employment and firm age in the first two years the firm is observed. For example, if a firm is first observed in 2009 \& 2010, it will be assigned to a firm size and age group based on its average employment and age between those two years. The estimates of the coefficients plotted in this figure are not statistically significant. 
Figure 4.2: Ethiopia estimated employment growth by firm size and age

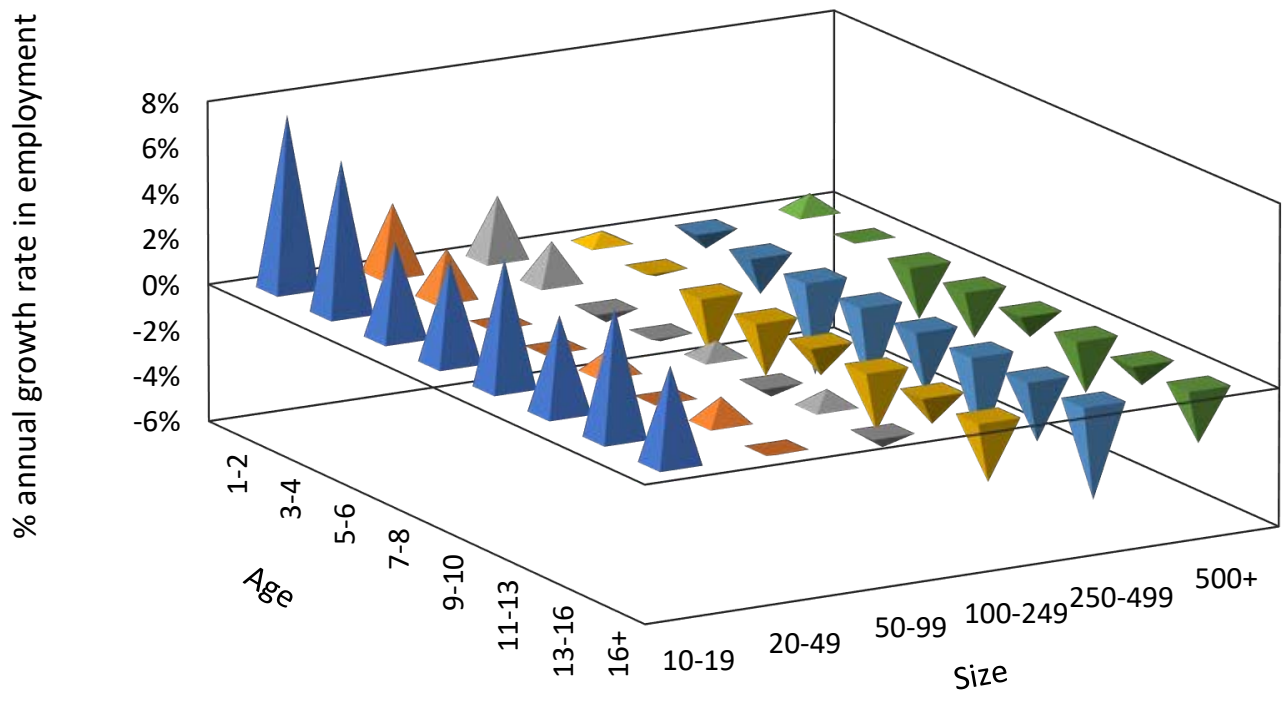

Notes: The coefficients plotted in this table come from regressions estimating the non-parametric relationship between employment growth and firm size and age groups. Firms are assigned to size and age groups based on the average employment and firm age in the first two years the firm is observed. All of the estimated coefficients are significant below the 0.01 level. 
Figure 5.1: Tanzania labor productivity dispersion results

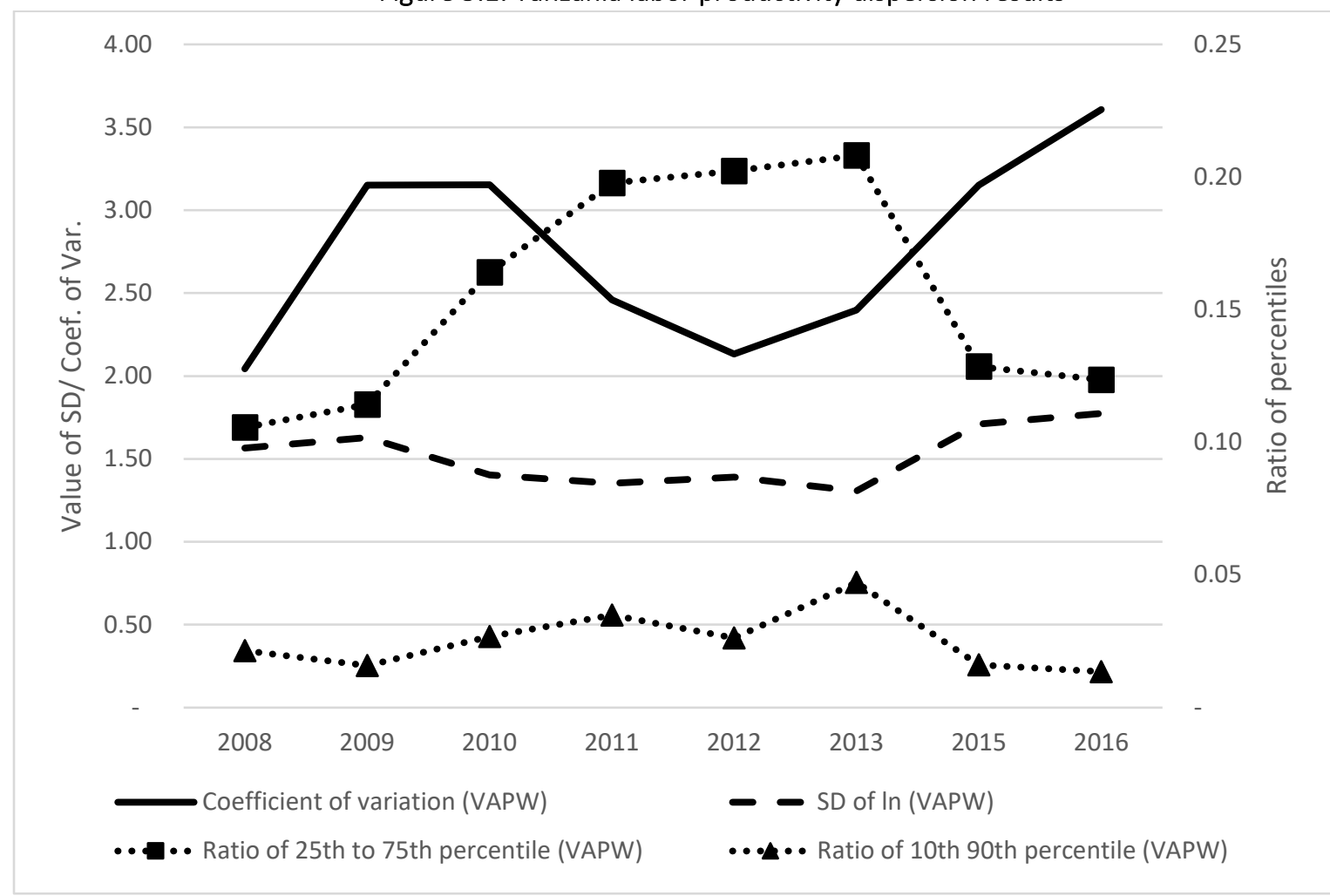

Notes: The sample used in this table corresponds to the sample used in our results for tables 4.2-4.3. Data are winsorized. The coefficient of variation is calculated as the standard deviation divided by the mean of value added per worker. The ratio of 25th to 75th and 10th to 90th percentiles are also calculated from levels of value added per worker. We include the standard deviation of the natural log of value added per worker, using the log value so that the scale of the standard deviation is manageable. If productivity dispersion is decreasing, we would expect the coefficient of variation and standard deviation measures to decline, and the ratios of the $10^{\text {th }}$ to $90^{\text {th }}$ and $25^{\text {th }}$ to $75^{\text {th }}$ percentiles would increase. As the ratio of the $10^{\text {th }}$ to $90^{\text {th }}$ percentile grows, that indicates that the bottom $10 \%$ account for a greater share of labor productivity. This in turn indicates convergence. A similar interpretation applies to the ratio of the $25^{\text {th }}$ to $70^{\text {th }}$ percentile. 
Figure 5.2: Ethiopia labor productivity dispersion results

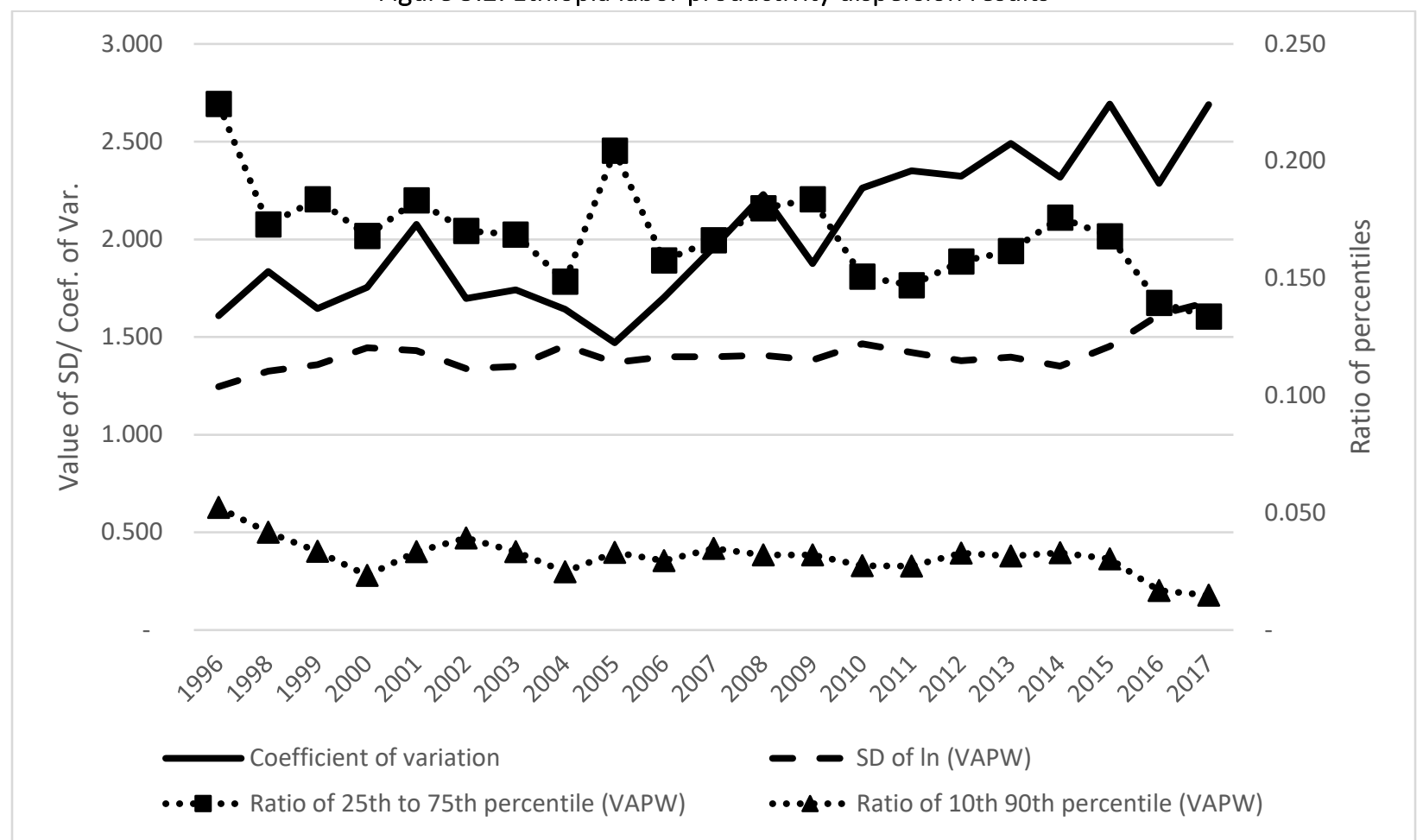

Notes: The sample used in this table corresponds to the sample used in our results for tables 4.2-4.3. Data are winsorized. The coefficient of variation is calculated as the standard deviation divided by the mean of value added per worker. The ratio of 25th to 75th and 10th to 90th percentiles are also calculated from levels of value added per worker. We include the standard deviation of the natural log of value added per worker, using the log value so that the scale of the standard deviation is manageable. If productivity dispersion is decreasing, we would expect the coefficient of variation and standard deviation measures to decline, and the ratios of the $10^{\text {th }}$ to $90^{\text {th }}$ and $25^{\text {th }}$ to $75^{\text {th }}$ percentiles would increase. As the ratio of the $10^{\text {th }}$ to $90^{\text {th }}$ percentile grows, that indicates that the bottom $10 \%$ account for a greater share of labor productivity. This in turn indicates convergence. A similar interpretation applies to the ratio of the $25^{\text {th }}$ to $70^{\text {th }}$ percentile. 


\begin{tabular}{|c|c|c|c|c|c|c|}
\hline Variable & $\begin{array}{l}\text { Number of Firms } \\
\text { (unweighted) }\end{array}$ & $\begin{array}{l}\text { Number of Firms } \\
\text { (weighted) }\end{array}$ & Mean & SD & Min & Max \\
\hline \multicolumn{7}{|c|}{ Tanzania (2013) } \\
\hline Employees (permanent) & 11,278 & 47,476 & 3 & 2 & 1 & 9 \\
\hline Value added (real 2016 USD) & 11,278 & 47,476 & 2,067 & 4,731 & $-38,889$ & 76,985 \\
\hline \multicolumn{7}{|c|}{ Ethiopia (2002-2014) } \\
\hline Employees (permanent) & 38,633 & 280,790 & 3 & 2 & 0 & 19 \\
\hline Owners & 38,694 & 281,249 & 2 & 13 & 0 & 891 \\
\hline Seasonal workers & 12,586 & 91,898 & 9 & 27 & 0 & 960 \\
\hline Value added (real 2016 USD) & 38,851 & 282,128 & 4,499 & 10,300 & $-84,665$ & 167,604 \\
\hline
\end{tabular}

Notes: The summary statistics presented in this table come from the available data covering manufacturing firms with less than 10 workers. In Tanzania, the data come from the 2013 Census of Industrial Production (CIP). The Ethiopia data come from repeated cross sections of the Small Scale Manufacturing Industries (SSI) surveys in 2002, 2006, 2008, 2011, and 2014. Owners and seasonal workers are not available in the CIP. The number of firms differs among the rows because some firms did not report the variable. Value added is converted to from nominal birr to 2016 birr and then to real 2016 USD using manufacturing-specific deflators, which are calculated from manufacturing value-added in current and constant LCU and the exchange rate in 2016 from WDI. 
Table 3.2: Summary statistics for firm-level panels

\begin{tabular}{|c|c|c|c|c|c|}
\hline \multicolumn{6}{|c|}{ Tanzania ASIP Panel (2008-2016) } \\
\hline Number of firms $=3,526$ & Obs & Mean & SD & Min & Max \\
\hline Employment & 8,423 & 83 & 285 & 9 & 8,157 \\
\hline Value added (real 2016 USD, $\$ 1,000)$ & 8,423 & 1,747 & 8,546 & 0 & 375,194 \\
\hline Value added (real 2016 TZS, million) & 8,423 & 3,803 & 18,605 & 0 & 816,829 \\
\hline Capital stock (real 2016 USD, \$1,000) & 8,423 & 1,143 & 6,557 & 0 & 234,195 \\
\hline Capital stock (real 2016 TZS, million) & 8,423 & 2,487 & 14,274 & 0 & 509,862 \\
\hline Large firm & 8,423 & 0.25 & 0.44 & 0 & 1 \\
\hline Foreign firm & 8,423 & 0.17 & 0.38 & 0 & 1 \\
\hline Exporting firm & 8,423 & 0.10 & 0.30 & 0 & 1 \\
\hline Public firm & 8,423 & 0.04 & 0.20 & 0 & 1 \\
\hline \multicolumn{6}{|c|}{ Ethiopia LMSM Panel (1996-2017) } \\
\hline Number of firms $=8,793$ & Obs & Mean & SD & Min & Max \\
\hline Employment & 26,179 & 92 & 272 & 1 & 12,419 \\
\hline Value added (real 2016 USD, $\$ 1,000)$ & 26,179 & 1,401 & 7,952 & 0 & 364,528 \\
\hline Value added (real 2016 BIRR, 1,000) & 26,179 & 30,444 & 172,805 & 0 & $7,921,749$ \\
\hline Capital stock (real 2016 USD, $\$ 1,000$ ) & 26,179 & 738 & 4,193 & $-2,089$ & 230,637 \\
\hline Capital stock (real 2016 BIRR, $\$ 1,000$ ) & 26,179 & 16,031 & 91,122 & $-45,406$ & $5,012,109$ \\
\hline Large firm & 26,179 & 0.27 & 0.44 & 0 & 1 \\
\hline Foreign firm & 26,179 & 0.06 & 0.23 & 0 & 1 \\
\hline Exporting firm & 26,179 & 0.05 & 0.22 & 0 & 1 \\
\hline Public firm & 26,179 & 0.07 & 0.26 & 0 & 1 \\
\hline
\end{tabular}

Notes: The listed number of observations is unweighted; we only apply weights to the 2013 ASIP data. The weighted number of observations in the ASIP panel is 8,578. The period covered for Tanzania is 2008-2016 and for Ethiopia is 1996-2017. Firms with 10-49 employees are classified as small firms while firms with 50 or more employees are classified as large firms (according to their average employment in the first two periods observed; this is time-invariant). The dummy variables for exporting, foreign, and public firms are timevariant and defined according to the firm's reporting in the current year. A firm is an exporter if it exported any of its production, is foreign if it reports foreign or joint venture ownership, and public if it reports being publicly owned. The variables for large firm, foreign firm, exporting firm, and public firm are all dummy variables that take a value of one if the firm has the given status, and zero otherwise. Firms are included in the LMSM panel after they have been observed for the first time, even if they reduce their employment below 10 workersthis is why we see a minimum employment of 1 worker in the Ethiopia data. The minimum employment in ASIP is 9 workers, however, only 20 firms in the ASIP panel report this 9 and it is likely a result of minor enumeration/reporting errors. Value added is converted to real 2016 USD in \$1,000 using manufacturing-specific deflators, which are calculated from manufacturing value-added in current and constant LCU and the exchange rate in 2016 from WDI. Capital information are missing for some firms; we exclude any large firms from the sample if they do not report machinery assets. 
Table 4.1: Firm-level regressions, levels of value added per worker and employment Regressions of year dummies \& firm characteristics on In(value added per worker) and In(employment)

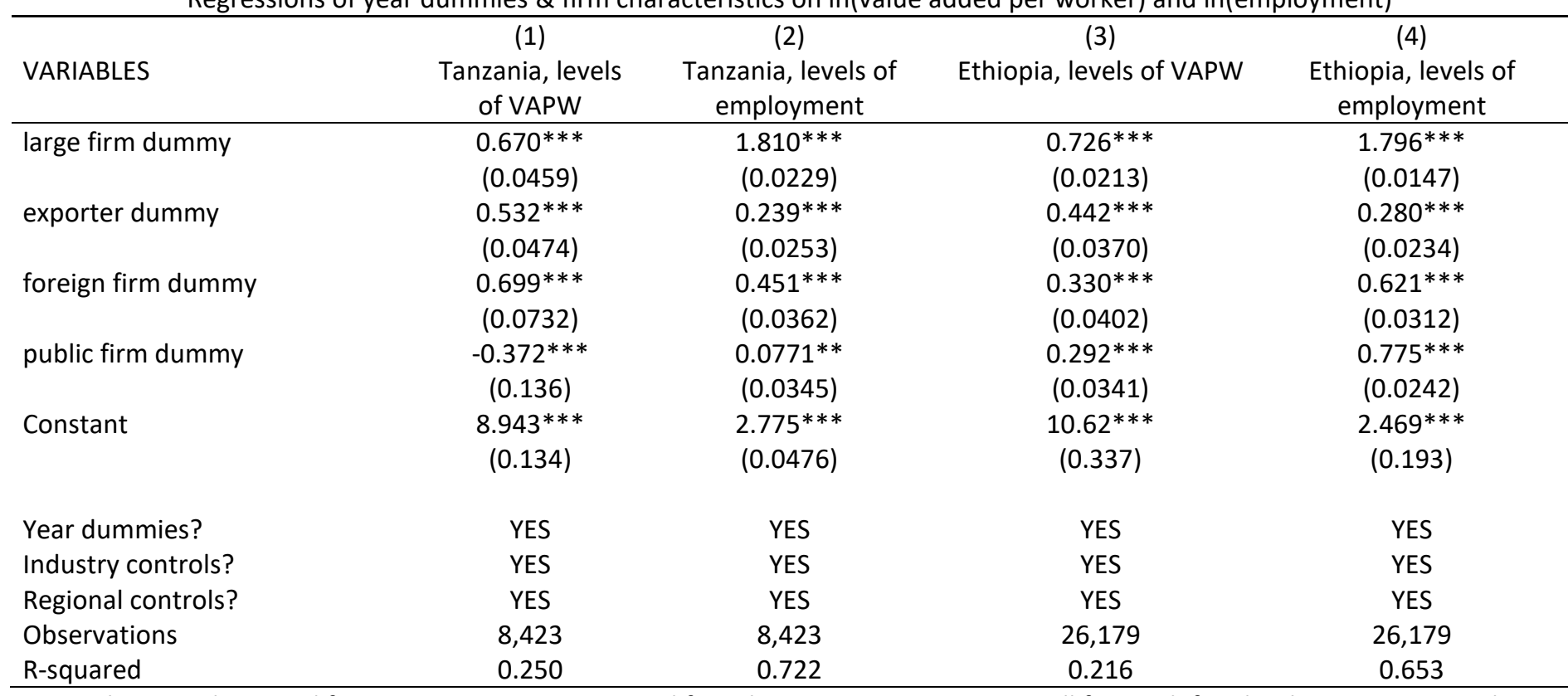

Notes: The period covered for Tanzania is 2008-2016 and for Ethiopia is 1996-2017. A small firm is defined as having 10-49 workers and a large firm is defined as having $50+$ workers. Robust standard errors in parentheses $* * * p<0.01, * * p<0.05, * p<0.1$ 
Table 4.2: Tanzania firm-level growth in value added per worker and employment 2008-2016

\begin{tabular}{|c|c|c|c|c|c|c|}
\hline VARIABLES & $\begin{array}{c}\text { (1) } \\
\text { Basic model }\end{array}$ & $\begin{array}{c}\text { (2) } \\
\text { large firm dummy }\end{array}$ & $\begin{array}{c}\text { (3) } \\
\text { exporter dummy }\end{array}$ & $\begin{array}{l}\text { (4) } \\
\text { foreign dummy }\end{array}$ & $\begin{array}{c}\text { (5) } \\
\text { public dummy }\end{array}$ & $\begin{array}{l}(6) \\
+ \text { all } \\
\end{array}$ \\
\hline \multicolumn{7}{|c|}{ Growth in value added per worker } \\
\hline \multirow[t]{2}{*}{ year (trend) } & $0.0240 * *$ & -0.0134 & 0.0133 & 0.0169 & $0.0243 * *$ & -0.0169 \\
\hline & $(0.00974)$ & $(0.0127)$ & $(0.0101)$ & $(0.0105)$ & $(0.00976)$ & $(0.0128)$ \\
\hline \multirow[t]{2}{*}{ year * large firm dummy } & & $0.0886 * * *$ & & & & $0.0717 * * *$ \\
\hline & & $(0.0196)$ & & & & $(0.0207)$ \\
\hline \multirow[t]{2}{*}{ year * exporter dummy } & & & $0.0641 * * *$ & & & $0.0515 * * *$ \\
\hline & & & $(0.0166)$ & & & $(0.0171)$ \\
\hline \multirow[t]{2}{*}{ year * foreign firm dummy } & & & & $0.0277^{*}$ & & 0.00877 \\
\hline & & & & $(0.0149)$ & & $(0.0154)$ \\
\hline \multirow[t]{2}{*}{ year * public firm dummy } & & & & & -0.0130 & -0.0100 \\
\hline & & & & & $(0.0309)$ & $(0.0307)$ \\
\hline Observations & 8,423 & 8,423 & 8,423 & 8,423 & 8,423 & 8,423 \\
\hline R-squared & 0.825 & 0.826 & 0.826 & 0.825 & 0.825 & 0.827 \\
\hline \multicolumn{7}{|c|}{ Growth in employment } \\
\hline \multirow[t]{2}{*}{ year (trend) } & $-5.73 e-05$ & $0.0133^{* * *}$ & -0.000941 & 0.00102 & -0.000108 & $0.0127 * * *$ \\
\hline & $(0.00397)$ & $(0.00416)$ & $(0.00396)$ & $(0.00403)$ & $(0.00398)$ & $(0.00412)$ \\
\hline \multirow[t]{2}{*}{ year $*$ large firm dummy } & & $-0.0318^{* * *}$ & & & & $-0.0346 * * *$ \\
\hline & & $(0.00844)$ & & & & $(0.00917)$ \\
\hline \multirow[t]{2}{*}{ year * exporter dummy } & & & 0.00532 & & & 0.0106 \\
\hline & & & $(0.00823)$ & & & $(0.00826)$ \\
\hline \multirow[t]{2}{*}{ year * foreign firm dummy } & & & & -0.00420 & & $4.76 e-05$ \\
\hline & & & & (0.00719) & & $(0.00742)$ \\
\hline \multirow[t]{2}{*}{ year * public firm dummy } & & & & & 0.00234 & 0.00245 \\
\hline & & & & & $(0.00864)$ & $(0.00850)$ \\
\hline Observations & 8,423 & 8,423 & 8,423 & 8,423 & 8,423 & 8,423 \\
\hline R-squared & 0.956 & 0.956 & 0.956 & 0.956 & 0.956 & 0.956 \\
\hline
\end{tabular}

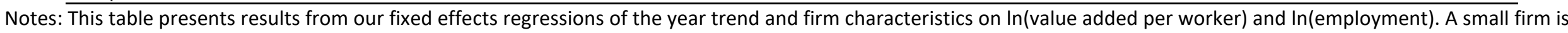

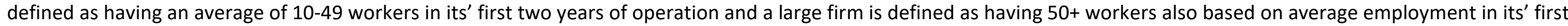
two years of operation. Robust standard errors in parentheses $* * * p<0.01, * * p<0.05, * p<0.1$ 
Table 4.3: Ethiopia firm-level growth in value added per worker and employment 1996-2017

\begin{tabular}{|c|c|c|c|c|c|c|}
\hline VARIABLES & $\begin{array}{c}\text { (1) } \\
\text { Basic model }\end{array}$ & $\begin{array}{c}\text { (2) } \\
\text { large firm dummy }\end{array}$ & $\begin{array}{c}\text { (3) } \\
\text { exporter dummy }\end{array}$ & $\begin{array}{l}\text { (4) } \\
\text { foreign dummy }\end{array}$ & $\begin{array}{c}\text { (5) } \\
\text { public dummy }\end{array}$ & $\begin{array}{l}(6) \\
+ \text { all }\end{array}$ \\
\hline \multicolumn{7}{|c|}{ Growth in value added per worker } \\
\hline \multirow[t]{2}{*}{ year (trend) } & $0.0292 * * *$ & $0.0317 * * *$ & $0.0288 * * *$ & $0.0288 * * *$ & $0.0299 * * *$ & $0.0314 * * *$ \\
\hline & $(0.00232)$ & $(0.00308)$ & $(0.00236)$ & $(0.00233)$ & $(0.00234)$ & $(0.00309)$ \\
\hline \multirow[t]{2}{*}{ year * large firm dummy } & & -0.00651 & & & & -0.00626 \\
\hline & & $(0.00462)$ & & & & $(0.00470)$ \\
\hline \multirow[t]{2}{*}{ year * exporter dummy } & & & 0.00378 & & & 0.00413 \\
\hline & & & $(0.00368)$ & & & $(0.00371)$ \\
\hline \multirow[t]{2}{*}{ year * foreign firm dummy } & & & & $0.00698 * *$ & & $0.00609 *$ \\
\hline & & & & $(0.00307)$ & & $(0.00312)$ \\
\hline \multirow[t]{2}{*}{ year * public firm dummy } & & & & & $-0.0119 * * *$ & $-0.0107 * * *$ \\
\hline & & & & & $(0.00359)$ & $(0.00366)$ \\
\hline Observations & 26,179 & 26,179 & 26,179 & 26,179 & 26,179 & 26,179 \\
\hline R-squared & 0.733 & 0.733 & 0.733 & 0.733 & 0.733 & 0.733 \\
\hline \multicolumn{7}{|c|}{ Growth in employment } \\
\hline \multirow[t]{2}{*}{ year (trend) } & $0.0164 * * *$ & $0.0334 * * *$ & $0.0151^{* * *}$ & $0.0162 * * *$ & $0.0159 * * *$ & $0.0323 * * *$ \\
\hline & $(0.00149)$ & $(0.00175)$ & $(0.00152)$ & $(0.00150)$ & $(0.00151)$ & $(0.00174)$ \\
\hline \multirow[t]{2}{*}{ year * large firm dummy } & & $-0.0445 * * *$ & & & & $-0.0488 * * *$ \\
\hline & & $(0.00301)$ & & & & $(0.00313)$ \\
\hline \multirow[t]{2}{*}{ year * exporter dummy } & & & $0.0113 * * *$ & & & $0.0154 * * *$ \\
\hline & & & $(0.00241)$ & & & $(0.00239)$ \\
\hline \multirow[t]{2}{*}{ year * foreign firm dummy } & & & & $0.00333^{*}$ & & $0.00529 * * *$ \\
\hline & & & & $(0.00182)$ & & (0.00184) \\
\hline \multirow[t]{2}{*}{ year * public firm dummy } & & & & & $0.00872 * * *$ & $0.0133 * * *$ \\
\hline & & & & & $(0.00235)$ & $(0.00238)$ \\
\hline Observations & 26,179 & 26,179 & 26,179 & 26,179 & 26,179 & 26,179 \\
\hline R-squared & 0.903 & 0.905 & 0.903 & 0.903 & 0.903 & 0.906 \\
\hline
\end{tabular}

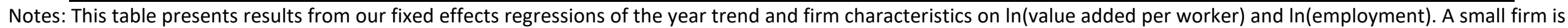

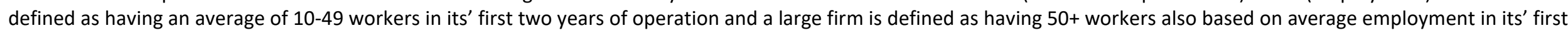
two years of operation. Robust standard errors in parentheses $* * * p<0.01, * * p<0.05, * p<0.1$ 
Table 4.4: Entry and exit in Tanzania, Ethiopia and Vietnam

\begin{tabular}{|c|c|c|c|c|c|c|c|c|c|}
\hline & \multicolumn{3}{|c|}{ All firms } & \multicolumn{3}{|c|}{ Small firms } & \multicolumn{3}{|c|}{ Large firms } \\
\hline & Firms & $\begin{array}{c}\text { Share of } \\
\text { employment }\end{array}$ & $\begin{array}{c}\text { Share of } \\
\text { sales }\end{array}$ & Firms & $\begin{array}{c}\text { Share of } \\
\text { employment }\end{array}$ & $\begin{array}{c}\text { Share of } \\
\text { sales }\end{array}$ & Firms & $\begin{array}{c}\text { Share of } \\
\text { employment }\end{array}$ & $\begin{array}{c}\text { Share of } \\
\text { sales }\end{array}$ \\
\hline \multicolumn{10}{|c|}{ Tanzania (2008-2016) } \\
\hline Exiters & 0.82 & 0.78 & 0.73 & 0.87 & 0.84 & 0.81 & 0.74 & 0.78 & 0.73 \\
\hline Entrants & 0.93 & 0.81 & 0.76 & 0.96 & 0.93 & 0.92 & 0.80 & 0.77 & 0.73 \\
\hline \multicolumn{10}{|c|}{ Ethiopia (2008-2016) } \\
\hline Exiters & 0.86 & 0.82 & 0.80 & 0.88 & 0.82 & 0.77 & 0.79 & 0.82 & 0.81 \\
\hline Entrants & 0.90 & 0.88 & 0.82 & 0.91 & 0.84 & 0.80 & 0.88 & 0.89 & 0.83 \\
\hline \multicolumn{10}{|c|}{ Ethiopia (2000-2017) } \\
\hline Exiters & 0.91 & 0.90 & 0.84 & 0.92 & 0.90 & 0.83 & 0.88 & 0.90 & 0.85 \\
\hline Entrants & 0.97 & 0.94 & 0.93 & 0.97 & 0.96 & 0.93 & 0.95 & 0.94 & 0.94 \\
\hline \multicolumn{10}{|c|}{ Ethiopia (2000-2011) } \\
\hline Exiters & 0.62 & 0.62 & 0.29 & 0.70 & 0.65 & 0.59 & 0.44 & 0.34 & 0.25 \\
\hline Entrants & 0.83 & 0.56 & 0.54 & 0.88 & 0.74 & 0.76 & 0.71 & 0.51 & 0.50 \\
\hline \multicolumn{10}{|c|}{ Vietnam (2008-2016) } \\
\hline Exiters & 0.48 & 0.18 & 0.16 & & & & & & \\
\hline Entrants & 0.75 & 0.45 & 0.49 & & & & & & \\
\hline \multicolumn{10}{|c|}{ Vietnam (2000-2017) } \\
\hline Exiters & 0.75 & 0.39 & 0.46 & & & & & & \\
\hline Entrants & 0.97 & 0.83 & 0.84 & & & & & & \\
\hline
\end{tabular}

Note: The "firms" column displays for exiters the percent of firms that existed in the initial year that did not survive to the final year, and for entrants the percent of firms that existed in the final year that did not exist in the initial year. For example, 82 percent of firms in the TZA ASIP panel in 2008 did not survive to 2016. 
Table 4.5: Tanzania sector-level growth in value added per worker and employment, 2008-2016

Fixed effects regressions of time trend on $\ln ($ value added per worker) and $\ln ($ employment)

\begin{tabular}{|c|c|c|c|c|c|c|c|c|c|}
\hline \multirow[b]{3}{*}{ VARIABLES } & (1) & $(2)$ & (3) & (4) & (5) & (6) & (7) & (8) & (9) \\
\hline & & All firms & & \multicolumn{3}{|c|}{ Small firms } & \multicolumn{3}{|c|}{ Large firms } \\
\hline & ISIC 2 digit & ISIC 3 digit & ISIC 4 digit & ISIC 2 digit & ISIC 3 digit & ISIC 4 digit & ISIC 2 digit & ISIC 3 digit & ISIC 4 digit \\
\hline \multicolumn{10}{|c|}{ Growth in value added per worker } \\
\hline \multirow[t]{2}{*}{ year } & $0.0565 * * *$ & $0.0625 * * *$ & $0.0543 * * *$ & 0.00951 & 0.0186 & 0.0159 & $0.0743 * * *$ & $0.0643 * * *$ & $0.0705 * * *$ \\
\hline & $(0.0178)$ & $(0.0150)$ & $(0.0151)$ & $(0.0268)$ & $(0.0200)$ & $(0.0172)$ & $(0.0217)$ & $(0.0193)$ & $(0.0183)$ \\
\hline \multirow[t]{2}{*}{ Constant } & $-103.3^{* * *}$ & $-115.6 * * *$ & $-99.20 * * *$ & -9.235 & -27.51 & -22.22 & $-138.9 * * *$ & $-118.9 * * *$ & $-131.6 * * *$ \\
\hline & $(35.84)$ & $(30.13)$ & $(30.42)$ & (53.90) & (40.17) & (34.52) & $(43.57)$ & $(38.80)$ & (36.89) \\
\hline Observations & 183 & 376 & 627 & 160 & 311 & 495 & 174 & 317 & 474 \\
\hline R-squared & 0.535 & 0.545 & 0.520 & 0.317 & 0.383 & 0.479 & 0.528 & 0.542 & 0.578 \\
\hline \multicolumn{10}{|c|}{ Growth in employment } \\
\hline \multirow[t]{2}{*}{ year } & $0.0698 * * *$ & $0.0790 * * *$ & $0.0570 * * *$ & $0.131^{* * *}$ & $0.124 * * *$ & $0.101 * * *$ & 0.0215 & 0.0147 & 0.00531 \\
\hline & $(0.0119)$ & $(0.0145)$ & $(0.0134)$ & $(0.0142)$ & $(0.0134)$ & $(0.0112)$ & (0.0134) & $(0.0142)$ & $(0.0132)$ \\
\hline \multirow[t]{2}{*}{ Constant } & $-133.1 * * *$ & $-152.6 * * *$ & $-108.8 * * *$ & $-258.0 * * *$ & $-244.2 * * *$ & $-198.2 * * *$ & -35.94 & -22.97 & -4.422 \\
\hline & $(23.98)$ & $(29.22)$ & $(26.91)$ & $(28.65)$ & $(26.87)$ & $(22.58)$ & $(27.02)$ & $(28.51)$ & $(26.55)$ \\
\hline Observations & 183 & 376 & 627 & 160 & 311 & 495 & 174 & 317 & 474 \\
\hline R-squared & 0.926 & 0.860 & 0.818 & 0.914 & 0.853 & 0.832 & 0.916 & 0.856 & 0.790 \\
\hline
\end{tabular}

Notes: This table presents results from regressing In(VAPW) on year, at the sector-level. Robust standard errors in parentheses. Small firms are defined as those

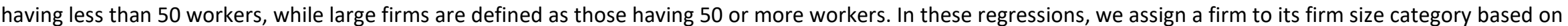
its average employment throughout the panel. $* * * p<0.01, * * p<0.05, * p<0.1$ 
Table 4.6: Ethiopia sector level growth in value added per worker and employment, 1996-2017

Fixed effects regressions of time trend on $\ln ($ value added per worker) and In(employment)

\begin{tabular}{|c|c|c|c|c|c|c|c|c|c|}
\hline & (1) & $(2)$ & (3) & (4) & (5) & (6) & (7) & $(8)$ & (9) \\
\hline VARIABLES & ISIC 2 digit & $\begin{array}{l}\text { All firms } \\
\text { ISIC } 3 \text { digit }\end{array}$ & ISIC 4 digit & ISIC 2 digit & $\begin{array}{l}\text { Small firms } \\
\text { ISIC } 3 \text { digit }\end{array}$ & ISIC 4 digit & ISIC 2 digit & $\begin{array}{l}\text { Large firms } \\
\text { ISIC } 3 \text { digit }\end{array}$ & ISIC 4 digit \\
\hline \multicolumn{10}{|c|}{ Growth in value added per worker } \\
\hline year & $\begin{array}{r}0.0509 * * * \\
(0.00511)\end{array}$ & $\begin{array}{r}0.0480 * * * \\
(0.00450)\end{array}$ & $\begin{array}{r}0.0430 * * * \\
(0.00366)\end{array}$ & $\begin{array}{c}0.0532 * * * \\
(0.00694)\end{array}$ & $\begin{array}{c}0.0438 * * * \\
(0.00572)\end{array}$ & $\begin{array}{r}0.0479 * * * \\
(0.00495)\end{array}$ & $\begin{array}{c}0.0459 * * * \\
(0.00458)\end{array}$ & $\begin{array}{c}0.0394 * * * \\
(0.00403)\end{array}$ & $\begin{array}{c}0.0382 * * * \\
(0.00351)\end{array}$ \\
\hline Constant & $\begin{array}{c}-89.93 * * * \\
(10.26)\end{array}$ & $\begin{array}{c}-84.20 * * * \\
(9.043)\end{array}$ & $\begin{array}{c}-74.20 * * * \\
(7.347)\end{array}$ & $\begin{array}{c}-95.02 * * * \\
(13.93)\end{array}$ & $\begin{array}{c}-76.24 * * * \\
(11.48)\end{array}$ & $\begin{array}{c}-84.53 * * * \\
(9.933)\end{array}$ & $\begin{array}{c}-79.77 * * * \\
(9.195)\end{array}$ & $\begin{array}{c}-66.88 * * * \\
(8.101)\end{array}$ & $\begin{array}{c}-64.33 * * * \\
(7.047)\end{array}$ \\
\hline Observations & 372 & 691 & 1,153 & 334 & 588 & 934 & 345 & 608 & 1,010 \\
\hline R-squared & 0.691 & 0.631 & 0.625 & 0.507 & 0.485 & 0.484 & 0.730 & 0.703 & 0.652 \\
\hline \multicolumn{10}{|c|}{ Growth in employment } \\
\hline year & $\begin{array}{c}0.0647^{* * *} \\
(0.00443)\end{array}$ & $\begin{array}{c}0.0462 * * * \\
(0.00428)\end{array}$ & $\begin{array}{c}0.0358 * * * \\
(0.00400)\end{array}$ & $\begin{array}{c}0.0754 * * * \\
(0.00478)\end{array}$ & $\begin{array}{c}0.0678 * * * \\
(0.00467)\end{array}$ & $\begin{array}{c}0.0660 * * * \\
(0.00445)\end{array}$ & $\begin{array}{c}0.0607 * * * \\
(0.00398)\end{array}$ & $\begin{array}{c}0.0416 * * * \\
(0.00438)\end{array}$ & $\begin{array}{c}0.0326 * * * \\
(0.00400)\end{array}$ \\
\hline Constant & $\begin{array}{c}-122.0 * * * \\
(8.888)\end{array}$ & $\begin{array}{c}-85.58 * * * \\
(8.596)\end{array}$ & $\begin{array}{c}-65.27 * * * \\
(8.030)\end{array}$ & $\begin{array}{c}-145.1 * * * \\
(9.595)\end{array}$ & $\begin{array}{c}-130.4^{* * *} \\
(9.368)\end{array}$ & $\begin{array}{c}-127.4 * * * \\
(8.937)\end{array}$ & $\begin{array}{c}-113.8^{* * *} \\
(7.989)\end{array}$ & $\begin{array}{c}-76.09 * * * \\
(8.788)\end{array}$ & $\begin{array}{c}-58.63 * * * \\
(8.023)\end{array}$ \\
\hline Observations & 372 & 691 & 1,153 & 334 & 588 & 934 & 345 & 608 & 1,010 \\
\hline R-squared & 0.916 & 0.877 & 0.815 & 0.898 & 0.852 & 0.792 & 0.898 & 0.814 & 0.741 \\
\hline
\end{tabular}

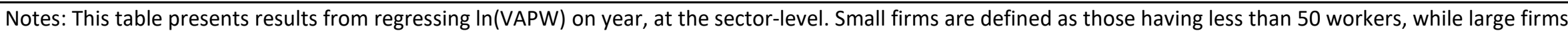
are defined as those having 50 or more workers. In these regressions, we assign a firm to its firm size category based on its average employment. Robust standard errors in parentheses. $* * * p<0.01, * * p<0.05, * p<0.1$ 
Table 4.7: Ethiopia SSI sector-level growth in value added per worker and employment, 2002-2014

Industry fixed effects regressions of time trend on $\ln ($ value added per worker) and In(employment)

\begin{tabular}{|c|c|c|c|}
\hline VARIABLES & $\begin{array}{c}(1) \\
E M P=\text { permanent }\end{array}$ & $\begin{array}{c}(2) \\
\mathrm{EMP}=\text { permanent }+ \text { seasonal } \& \\
\text { temporary }\end{array}$ & $\begin{array}{c}(3) \\
\text { EMP }=\text { permanent }+ \text { seasonal } \& \\
\text { temporary + owners }\end{array}$ \\
\hline \multirow[t]{2}{*}{ Year } & 0.0244 & 0.0135 & 0.00693 \\
\hline & $(0.0151)$ & $(0.0171)$ & $(0.0166)$ \\
\hline Constant & -38.52 & -17.31 & -4.389 \\
\hline Observations & 103 & 103 & 103 \\
\hline R-squared & 0.301 & 0.328 & 0.306 \\
\hline \multicolumn{4}{|c|}{ Growth in employment } \\
\hline \multirow[t]{2}{*}{ Year } & $0.160 * * *$ & $0.171^{* * *}$ & $0.178 * * *$ \\
\hline & $(0.0273)$ & $(0.0328)$ & $(0.0313)$ \\
\hline Observations & 104 & 104 & 104 \\
\hline R-squared & 0.832 & 0.802 & 0.813 \\
\hline
\end{tabular}

Notes: The data was aggregated from the firm-level to the ISIC 3-digit level. Robust standard errors in parentheses

$* * * \mathrm{p}<0.01, * * \mathrm{p}<0.05, * \mathrm{p}<0.1$ 
Table 5.1: Tanzania firm-level convergence

\begin{tabular}{|c|c|c|c|c|c|}
\hline VARIABLES & $\begin{array}{c}\text { (1) } \\
\text { Basic model }\end{array}$ & $\begin{array}{c}(2) \\
\text { With industry controls }\end{array}$ & $\begin{array}{c}\text { (3) } \\
+ \text { interaction with } \\
\text { exporter dummy }\end{array}$ & $\begin{array}{c}\text { (4) } \\
+ \text { interaction with } \\
\text { foreign dummy } \\
\end{array}$ & $\begin{array}{c}\text { (5) } \\
\text { +interaction with large } \\
\text { firm dummy }\end{array}$ \\
\hline In(initial VAPW) & $\begin{array}{c}-0.0637 * * * \\
(0.0236)\end{array}$ & $\begin{array}{c}-0.0738 * * * \\
(0.0261)\end{array}$ & $\begin{array}{c}-0.0685^{* *} \\
(0.0270)\end{array}$ & $\begin{array}{c}-0.0806 * * * \\
(0.0272)\end{array}$ & $\begin{array}{c}-0.0850 * * * \\
(0.0287)\end{array}$ \\
\hline Exporter dummy interaction & & & $\begin{array}{l}-0.00633 \\
(0.00878)\end{array}$ & & \\
\hline Foreign firm dummy interaction & & & & $\begin{array}{c}0.00916 \\
(0.00706)\end{array}$ & \\
\hline Large firm dummy interaction & & & & & $\begin{array}{c}0.00849 \\
(0.00761)\end{array}$ \\
\hline Constant & $\begin{array}{c}0.586 * * * \\
(0.224)\end{array}$ & $\begin{array}{c}0.715^{* * *} \\
(0.247)\end{array}$ & $\begin{array}{c}0.679 * * * \\
(0.252)\end{array}$ & $\begin{array}{c}0.747^{* * *} \\
(0.249)\end{array}$ & $\begin{array}{c}0.790 * * * \\
(0.259)\end{array}$ \\
\hline 2-digit ISIC dummies? & NO & YES & YES & YES & YES \\
\hline Observations & 518 & 518 & 518 & 518 & 518 \\
\hline R-squared & 0.021 & 0.082 & 0.083 & 0.085 & 0.084 \\
\hline
\end{tabular}

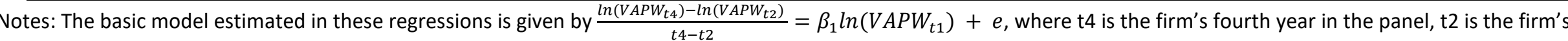

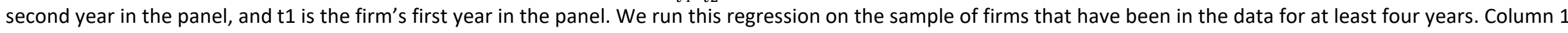

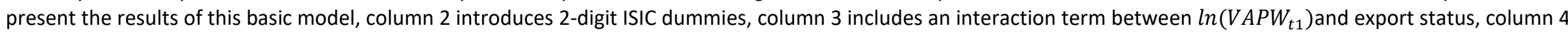

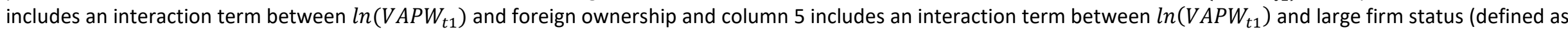

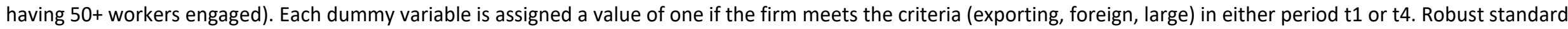
errors in parentheses. ${ }^{* * *} p<0.01, * * p<0.05, * p<0.1$ 
Table 5.2: Ethiopia firm-level convergence

\begin{tabular}{|c|c|c|c|c|c|}
\hline VARIABLES & $\begin{array}{c}\text { (1) } \\
\text { Basic model }\end{array}$ & $\begin{array}{c}\text { (2) } \\
\text { With industry controls }\end{array}$ & $\begin{array}{c}(3) \\
+ \text { interaction with } \\
\text { exporter dummy }\end{array}$ & $\begin{array}{c}\text { (4) } \\
+ \text { interaction with } \\
\text { foreign dummy } \\
\end{array}$ & $\begin{array}{c}\text { (5) } \\
\text { +interaction with large } \\
\text { firm dummy }\end{array}$ \\
\hline In(initial VAPW) & $\begin{array}{c}-0.0597 * * * \\
(0.0118)\end{array}$ & $\begin{array}{c}-0.0711^{* * *} \\
(0.0131)\end{array}$ & $\begin{array}{c}-0.0718 * * * \\
(0.0132)\end{array}$ & $\begin{array}{c}-0.0692 * * * \\
(0.0131)\end{array}$ & $\begin{array}{c}-0.0765 * * * \\
(0.0141)\end{array}$ \\
\hline Exporter dummy interaction & & & $\begin{array}{c}0.00290 \\
(0.00596)\end{array}$ & & \\
\hline Foreign firm dummy interaction & & & & $\begin{array}{l}-0.00569 \\
(0.00510)\end{array}$ & \\
\hline Large firm dummy interaction & & & & & $\begin{array}{c}0.00444 \\
(0.00290)\end{array}$ \\
\hline Constant & $\begin{array}{c}0.671 * * * \\
(0.133)\end{array}$ & $\begin{array}{c}0.811^{* * *} \\
(0.151)\end{array}$ & $\begin{array}{c}0.817^{* * *} \\
(0.152)\end{array}$ & $\begin{array}{c}0.792 * * * \\
(0.151)\end{array}$ & $\begin{array}{c}0.858 * * * \\
(0.159)\end{array}$ \\
\hline 2-digit ISIC dummies? & NO & YES & YES & YES & YES \\
\hline Observations & 1,821 & 1,821 & 1,821 & 1,821 & 1,821 \\
\hline R-squared & 0.018 & 0.032 & 0.032 & 0.033 & 0.033 \\
\hline
\end{tabular}

R-squared

$$
t 4-t 2
$$

$=\beta_{1} \ln \left(V A P W_{t 1}\right)+e$, where $\mathrm{t} 4$ is the firm's fourth year in the panel, $\mathrm{t} 2$ is the firm's

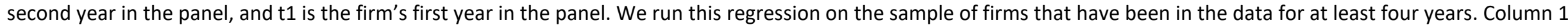

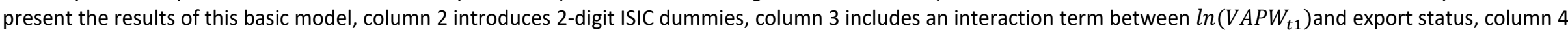

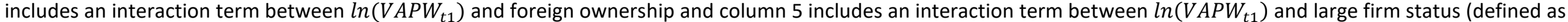

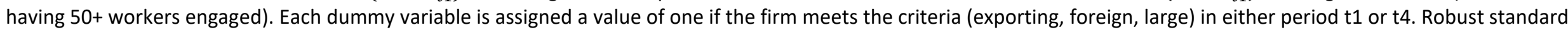
errors in parentheses. $* * * p<0.01, * * p<0.05, * p<0.1$. 


\begin{tabular}{|c|c|c|c|c|c|c|}
\hline & (1) & (2) & (3) & (4) & (5) & (6) \\
\hline \multirow[t]{2}{*}{ VARIABLES } & \multicolumn{3}{|c|}{ UNWEIGHTED } & \multicolumn{3}{|c|}{ WEIGHTED } \\
\hline & 2-digit & 3-digit & 4-digit & 2-digit & 3-digit & 4-digit \\
\hline \multirow[t]{2}{*}{ In (VAPW_2008) } & $-0.0984 * * *$ & $-0.0813^{* * *}$ & $-0.0630 * *$ & $-0.0633 * * *$ & $-0.0669 * * *$ & $-0.0664 * * *$ \\
\hline & $(0.0338)$ & $(0.0262)$ & $(0.0244)$ & $(0.0164)$ & $(0.0196)$ & $(0.0216)$ \\
\hline \multirow[t]{2}{*}{ Constant } & $1.090 * * *$ & $0.912 * * *$ & $0.709 * * *$ & $0.724 * * *$ & $0.772 * * *$ & $0.778 * * *$ \\
\hline & $(0.362)$ & $(0.280)$ & $(0.263)$ & $(0.184)$ & $(0.220)$ & $(0.243)$ \\
\hline Observations & 22 & 38 & 57 & 22 & 38 & 57 \\
\hline R-squared & 0.240 & 0.182 & 0.114 & 0.299 & 0.298 & 0.239 \\
\hline
\end{tabular}

Notes: The basic model estimated in these regressions is given by $\frac{\ln \left(V A P W_{2016}\right)-\ln \left(V A P W_{2009}\right)}{7}=\beta_{1} \ln \left(V A P W_{2008}\right)+e$. Column 1 presents the results for Tanzania from regressions at the 2-digit ISIC level; column 2 presents results at the 3-digit ISIC level, and column 3 presents results at the 4-digit ISIC level; finally, columns 4-6 present the same sequence of results for Tanzania. The weights used in columns 4-6 are calculated using the average of sector and total VA in 2009 and 2016 . Robust standard errors in parentheses. $* * * p<0.01, * * p<0.05, * p<0.1$ 
Table 5.4: Ethiopia sector-level convergence, 1998-2017, all firms

\begin{tabular}{|c|c|c|c|c|c|c|}
\hline \multirow{3}{*}{ VARIABLES } & (1) & $(2)$ & (3) & (4) & (5) & (6) \\
\hline & \multicolumn{3}{|c|}{ UNWEIGHTED } & \multicolumn{3}{|c|}{ WEIGHTED } \\
\hline & 2-digit & 3-digit & 4-digit & 2-digit & 3-digit & 4-digit \\
\hline \multirow[t]{2}{*}{ In (VAPW_1996) } & -0.00709 & -0.0105 & $-0.0244 * *$ & -0.0138 & $-0.0174^{*}$ & $-0.0162 *$ \\
\hline & $(0.00850)$ & (0.00692) & $(0.0102)$ & (0.00966) & $(0.00905)$ & $(0.00941)$ \\
\hline \multirow[t]{2}{*}{ Constant } & 0.127 & $0.163 * *$ & $0.325 * *$ & 0.203 & $0.249 * *$ & $0.241^{* *}$ \\
\hline & $(0.101)$ & $(0.0783)$ & $(0.120)$ & $(0.123)$ & $(0.111)$ & $(0.116)$ \\
\hline Observations & 15 & 25 & 36 & 15 & 25 & 36 \\
\hline R-squared & 0.019 & 0.039 & 0.106 & 0.147 & 0.124 & 0.078 \\
\hline
\end{tabular}

Notes: The basic model estimated in these regressions is given by $\frac{\left.\ln \left(V A P W_{2017}\right)-\ln 1998\right)}{19}=\beta_{1} \ln \left(V A P W_{1996}\right)+e$. Column 1 presents the

results for Ethiopia from regressions at the 2-digit ISIC level; column 2 presents results at the 3-digit ISIC level, and column 3 presents results at the 4-digit ISIC level; finally, columns 4-6 present the same sequence of results, but weighted. The weights used in columns 4-6 are calculated using the average of sector and total VA in 1998 and 2017. Robust standard errors in parentheses. $* * * p<0.01, * * p<0.05, * p<0.1$ 
Table 5.5: Ethiopia SSI \& LMSM sector-level convergence, 2002-2014

\begin{tabular}{|c|c|c|c|c|c|}
\hline VARIABLES & $\begin{array}{c}\text { (1) } \\
\text { sSI only }\end{array}$ & $\begin{array}{c}\text { (2) } \\
\text { LMSM only }\end{array}$ & $\begin{array}{c}(3) \\
\text { SSI \& LMSM combined }\end{array}$ & $\begin{array}{c}(4) \\
\text { SSI \& LMSM as } \\
\text { separate observations }\end{array}$ & $\begin{array}{c}(5) \\
\text { SSI \& LMSM as } \\
\text { separate observations, } \\
\text { with interaction term }\end{array}$ \\
\hline \multicolumn{6}{|c|}{ SSI EMP DEFINITION 1 = PERMANENT WORKERS } \\
\hline In (VAPW_2002) & $\begin{array}{l}-0.0357 \\
(0.0290)\end{array}$ & $\begin{array}{c}-0.0358 * * * \\
(0.0106)\end{array}$ & $\begin{array}{c}-0.0536^{* * *} \\
(0.0181)\end{array}$ & $\begin{array}{l}-0.00729 \\
(0.00996)\end{array}$ & $\begin{array}{c}-0.0336 * * * \\
(0.0106)\end{array}$ \\
\hline SSI dummy * In (VAPW_2002) & & & & & $\begin{array}{c}-0.00760 * * * \\
(0.00162)\end{array}$ \\
\hline Constant & $\begin{array}{c}0.399 \\
(0.316)\end{array}$ & $\begin{array}{c}0.483 * * * \\
(0.129)\end{array}$ & $\begin{array}{c}0.676 * * * \\
(0.215)\end{array}$ & $\begin{array}{c}0.126 \\
(0.118)\end{array}$ & $\begin{array}{c}0.457^{* * *} \\
(0.129)\end{array}$ \\
\hline $\begin{array}{l}\text { Observations } \\
\text { R-squared }\end{array}$ & $\begin{array}{c}19 \\
0.093\end{array}$ & $\begin{array}{c}27 \\
0.347\end{array}$ & $\begin{array}{c}31 \\
0.512\end{array}$ & $\begin{array}{c}46 \\
0.016\end{array}$ & $\begin{array}{c}46 \\
0.256\end{array}$ \\
\hline \multicolumn{6}{|c|}{ SSI EMP DEFINITION 2 = PERMANENT + SEASONAL WORKERS } \\
\hline In (VAPW_2002) & $\begin{array}{l}-0.0305 \\
(0.0265)\end{array}$ & $\begin{array}{c}-0.0358 * * * \\
(0.0106)\end{array}$ & $\begin{array}{c}-0.0435^{* *} \\
(0.0177)\end{array}$ & $\begin{array}{c}-0.00257 \\
(0.00882)\end{array}$ & $\begin{array}{c}-0.0319 * * * \\
(0.0101)\end{array}$ \\
\hline SSI dummy * In (VAPW_2002) & & & & & $\begin{array}{c}-0.00877^{* * *} \\
(0.00186)\end{array}$ \\
\hline Constant & $\begin{array}{c}0.332 \\
(0.282)\end{array}$ & $\begin{array}{c}0.483 * * * \\
(0.129)\end{array}$ & $\begin{array}{c}0.535^{* *} \\
(0.210)\end{array}$ & $\begin{array}{l}0.0701 \\
(0.104)\end{array}$ & $\begin{array}{c}0.437 * * * \\
(0.123)\end{array}$ \\
\hline Observations & 19 & 27 & 31 & 46 & 46 \\
\hline R-squared & 0.068 & 0.347 & 0.338 & 0.002 & 0.256 \\
\hline
\end{tabular}

Notes: The data are aggregated from the firm-level to the ISIC 3-digit sector level. The basic model estimated in these regressions is given by

$\frac{\ln \left(V A P W_{2014}\right)-\ln \left(V A P W_{2002}\right)}{12}=\beta_{1} \ln \left(V A P W_{2002}\right)+e$. Column 1 presents the results for Ethiopia from regressions using only the SSI sample, column 2 presents results using only the LMSM sample, column 3 presents results from adding the SSI \& LMSM together and combining them into one sector-level panel, column 4 presents results when SSI \& LMSM are both included in the regression but kept as distinct observations at the sector-level, and column 5 follows the model in column 4 but introduces an interaction between the SSI indicator and $\ln \left(V A P W_{2002}\right)$. No weights are used. VAPW at the sector level is calculated as the total VA of all firms in the sector divided by the total EMP of all firms in the sector. We test these results with different measures of employment from the SSI data, and have additional robustness checks with the LMSM data showing that our results do not change when including seasonal/temporary workers. Robust standard errors in parentheses. ${ }^{* * *} \mathrm{p}<0.01, * * \mathrm{p}<0.05, * \mathrm{p}<0.1$ 
Table 6.1 Tanzania and Ethiopia in comparative context

\begin{tabular}{lcccc}
\hline & $\begin{array}{c}\text { per-capita } \\
\text { GDP, in } \\
\text { current US\$ } \\
(2017)\end{array}$ & $\begin{array}{c}\text { per-capita } \\
\text { GDP, in } \\
\text { current PPP \$ } \\
\text { (2017) }\end{array}$ & $\begin{array}{c}\text { manufacturing } \\
\text { economy-wital-labor } \\
\text { catio, 2015 } \\
\text { rapital-labor }\end{array}$ & $\begin{array}{c}\text { catio (machinery } \\
\text { \& equipment), } \\
2010-17\end{array}$ \\
\hline Tanzania & 4.9 & 6.6 & 9.9 & 39.4 \\
Ethiopia & 3.5 & 5.2 & 3.4 & 18.7 \\
\hline
\end{tabular}

Notes: (values for Czech Republic = 100) 
Table 6.2 Comparative capital-labor ratios in manufacturing, 2010-17 average

(value of total manufacturing capital-labor ratio for Czech Republic $=100$ )

\begin{tabular}{|c|c|c|c|c|}
\hline & All & $\begin{array}{c}\text { Food products, } \\
\text { beverages, and tobacco }\end{array}$ & $\begin{array}{l}\text { Rubber \& plastics products, } \\
\text { and other non-metallic } \\
\text { mineral products }\end{array}$ & $\begin{array}{l}\text { Textiles, wearing } \\
\text { apparel, leather }\end{array}$ \\
\hline \multicolumn{5}{|c|}{ Tanzania } \\
\hline Total & 39.4 & 31.1 & 74.0 & 40.0 \\
\hline Small & 29.0 & 37.8 & 23.4 & 19.9 \\
\hline Large & 41.4 & 30.7 & 92.6 & 41.5 \\
\hline Foreign & 38.6 & 26.5 & 126.7 & 48.0 \\
\hline Exporting & 40.3 & 37.2 & & \\
\hline Top 10\% large & 224.1 & & & \\
\hline Middle $80 \%$ large & 29.6 & & & \\
\hline Bottom $10 \%$ large & 11.0 & & & \\
\hline New large & 54.4 & & & \\
\hline Old large & 30.8 & & & \\
\hline \multicolumn{5}{|c|}{ Ethiopia } \\
\hline Total & 18.7 & 22.3 & 20.0 & 18.4 \\
\hline Small & 13.8 & 19.2 & 8.9 & 17.2 \\
\hline Large & 19.9 & 23.6 & 23.9 & 18.5 \\
\hline Foreign & 25.6 & 38.0 & 27.0 & 17.9 \\
\hline Exporting & 19.7 & & & 20.9 \\
\hline Top 10\% large & 74.9 & & & \\
\hline Middle $80 \%$ large & 13.8 & & & \\
\hline Bottom 10\% large & 7.1 & & & \\
\hline New large & 22.3 & & & \\
\hline Old large & 16.2 & & & \\
\hline \multicolumn{5}{|c|}{$\begin{array}{l}\text { Notes: } 2010-2017 \text { average capital-labor (K/L) ratios are calculated as } \$ 1,000 \text { constant PPP per worker for TZA and ETH and Czech Republic. Firms with } 10-49 \\
\text { employees are classified as small firms while firms with } 50 \text { or more employees are classified as large firms. The Tanzania employment numbers used in these } \\
\text { calculations cover all workers, while the Ethiopia employment numbers are limited to permanent workers. Foreign firms are defined as those with foreign } \\
\text { ownership for the majority of years or at least one year with data available only for two years. Exporters are firms reporting exports in every year. The definitions } \\
\text { used for foreign and exporting firms is constructed to create a time-invariant variable in order to track the same group of firms over time and produce consistent } \\
\text { aggregate estimates. Among the large firms, we further classify firms by capital intensity in the following way. First, we rank firms by capital - labor ratio (K/L) and } \\
\text { then choose the top } 10 \% \text { firms according to } \mathrm{K} / \mathrm{L} \text { for the initial year of each panel (1996 for Ethiopia and } 2008 \text { for Tanzania). In the next year, we add to these new } \\
\text { firms according to their K/L ratio in the same way. Thus, once a firm is classified as in the top } 10 \% \text { according to capital intensity, it remains in that group for every } \\
\text { year it is observed. We follow the same procedure to classify the bottom } 10 \% \text { of firms, and the middle } 80 \% \text { is defined as the residual. Among the large firms, we } \\
\text { further classify firms that enter the sample in } 2010 \text { or later as new entrants relative to firms that are in the sample prior to } 2010 \text {. }\end{array}$} \\
\hline
\end{tabular}


Table 6.3: Payroll share of total value-added

\begin{tabular}{|c|c|c|c|c|}
\hline & All & $\begin{array}{c}\text { Food products, } \\
\text { beverages, and tobacco }\end{array}$ & $\begin{array}{l}\text { Rubber \& plastics products, } \\
\text { and other non-metallic } \\
\text { mineral products }\end{array}$ & $\begin{array}{l}\text { Textiles, wearing } \\
\text { apparel, leather }\end{array}$ \\
\hline \multicolumn{5}{|c|}{ Tanzania } \\
\hline Total & 12.8 & 12.7 & 9.9 & 19.5 \\
\hline Small & 11.9 & 10.2 & 14.7 & 12.8 \\
\hline Large & 13.0 & 12.9 & 9.8 & 20.5 \\
\hline Foreign & 15.0 & 15.2 & 11.6 & 18.9 \\
\hline Exporting & 10.1 & 10.0 & & \\
\hline Top 10\% large & 10.9 & & & \\
\hline Middle $80 \%$ large & 14.0 & & & \\
\hline Bottom $10 \%$ large & 16.7 & & & \\
\hline New large & 11.1 & & & \\
\hline Old large & 15.4 & & & \\
\hline \multicolumn{5}{|c|}{ Ethiopia } \\
\hline Total & 11.2 & 10.2 & 11.0 & 23.7 \\
\hline Small & 12.1 & 11.5 & 13.8 & 71.3 \\
\hline Large & 11.1 & 10.1 & 10.7 & 23.9 \\
\hline Foreign & 10.3 & 6.4 & 8.5 & 28.9 \\
\hline Exporting & 21.6 & 32.4 & & 24.6 \\
\hline Top 10\% large & 8.1 & & & \\
\hline Middle $80 \%$ large & 12.1 & & & \\
\hline Bottom $10 \%$ large & 12.6 & & & \\
\hline New large & 11.5 & & & \\
\hline Old large & 11.3 & & & \\
\hline
\end{tabular}

Notes: See the notes in table 6.2 for variable definitions. 
Figure 6.1 Manufacturing and economy-wide capital-labor ratios, Tanzania, Ethiopia, and Czech Republic

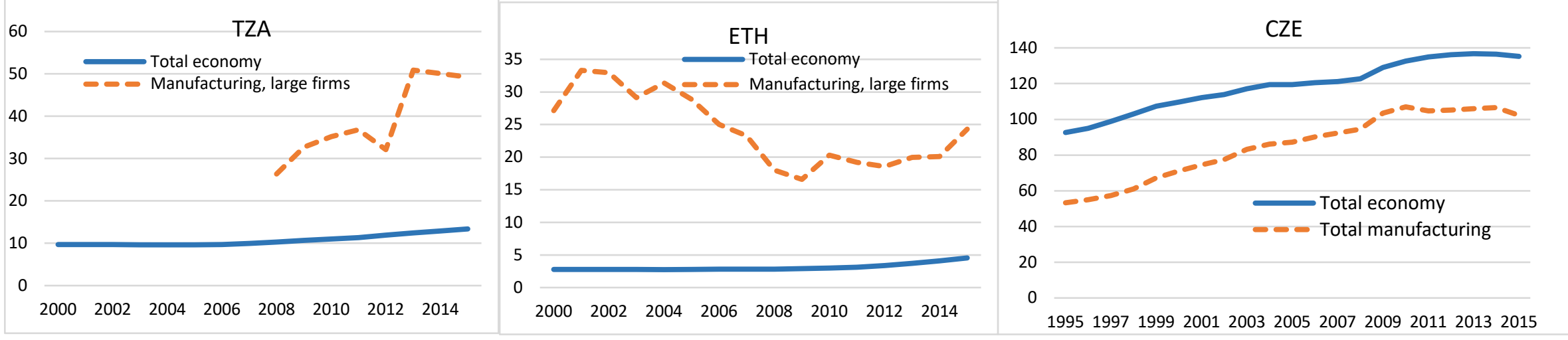

Notes: Capital-labor (K/L) ratios are in \$1,000 constant 2011 PPP \$. PPP convertors differ for machinery \& equipment and buildings \& structures, and they are both from ICP. For buildings and structures, the PPP conversion for construction from ICP is used. 2010 PPP is calculated by using the growth rate between 2011 and 2017 PPPs from ICP, a similar approach used in WDI. 
Figure 6.2 Global declines in manufacturing employment

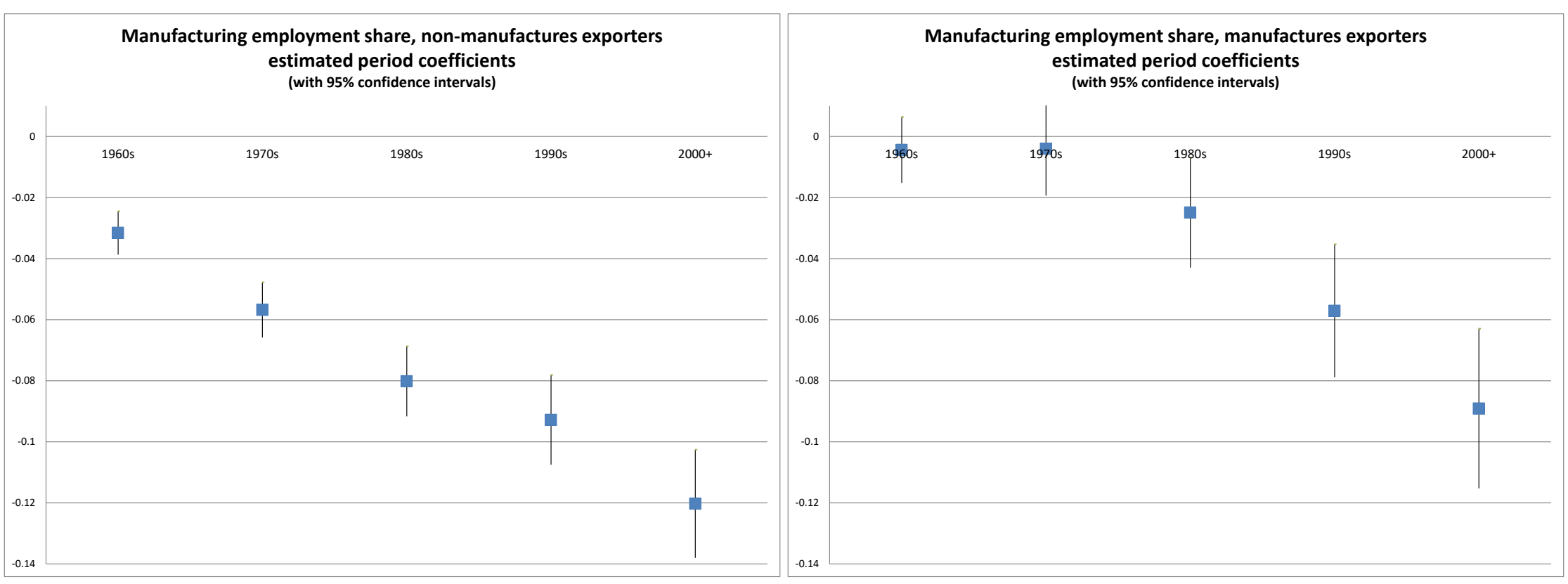

Notes: Estimated coefficients on decade dummies from a regression where manufacturing shares are regressed on income, population (and their squares), country fixed effects, and period dummies.

Source: Rodrik (2016) 
Figure 6.3 Declines in low-skill employment

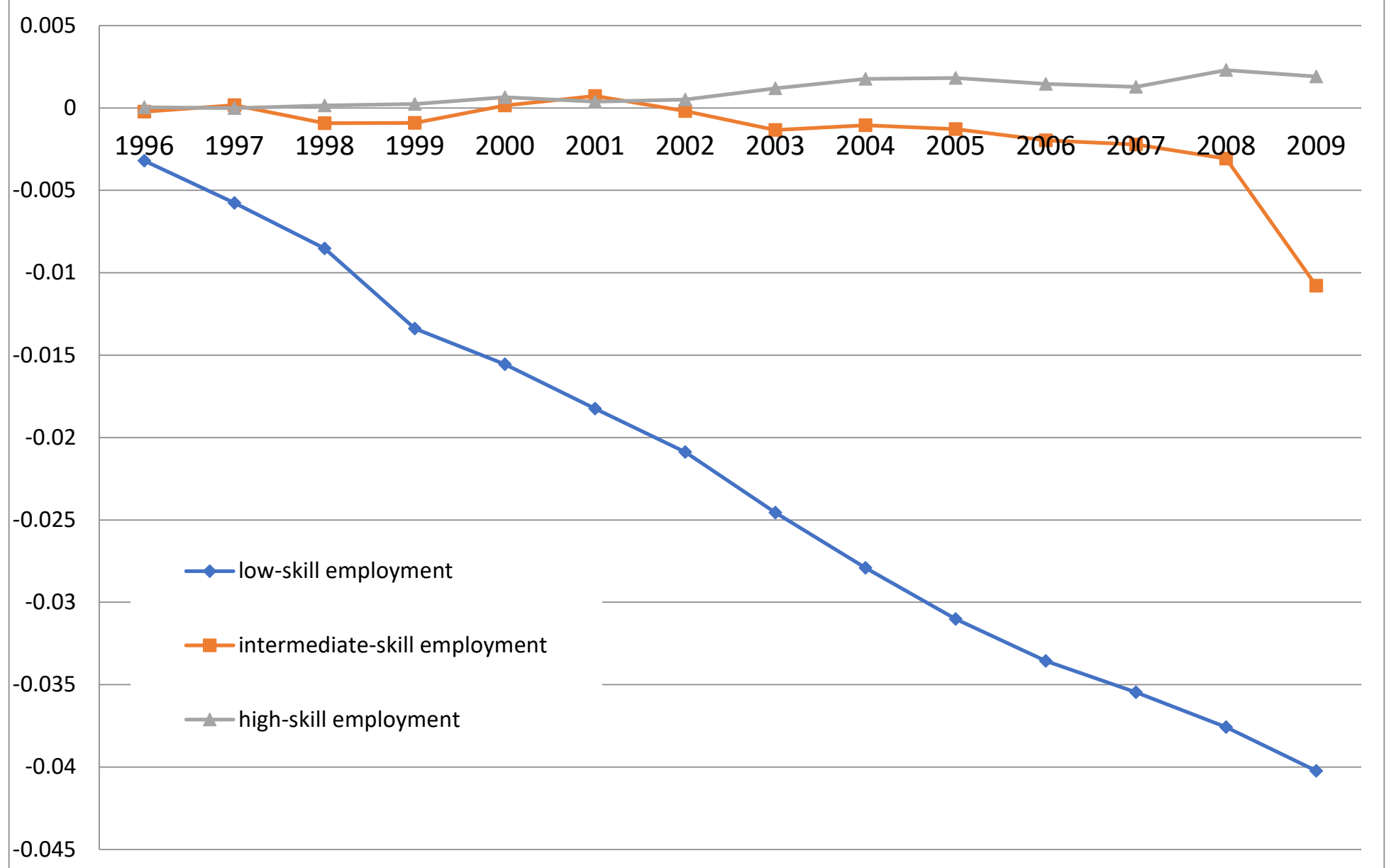

Notes: Estimated coefficients on year dummies from a regression where manufacturing employment shares (by skill category) are regressed on income, population (and their squares), country fixed effects, and year dummies.

Source: Rodrik (2016) 
Figure 6.4 Analytics of technology choice

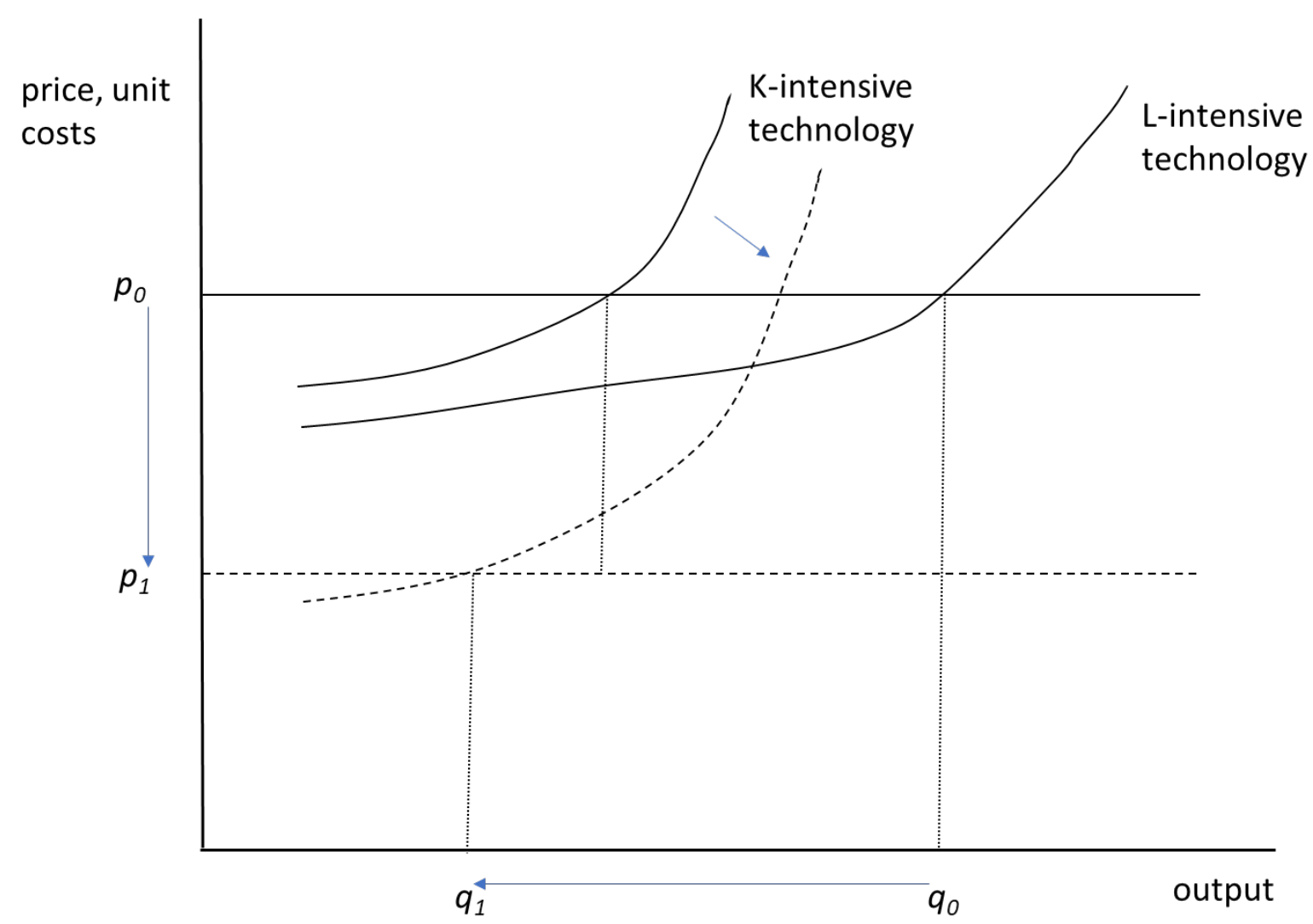

Source: Authors. 


\section{Appendix}

Figure A1. Tanzania estimated growth in VAPW and Employment by Firm Size Group

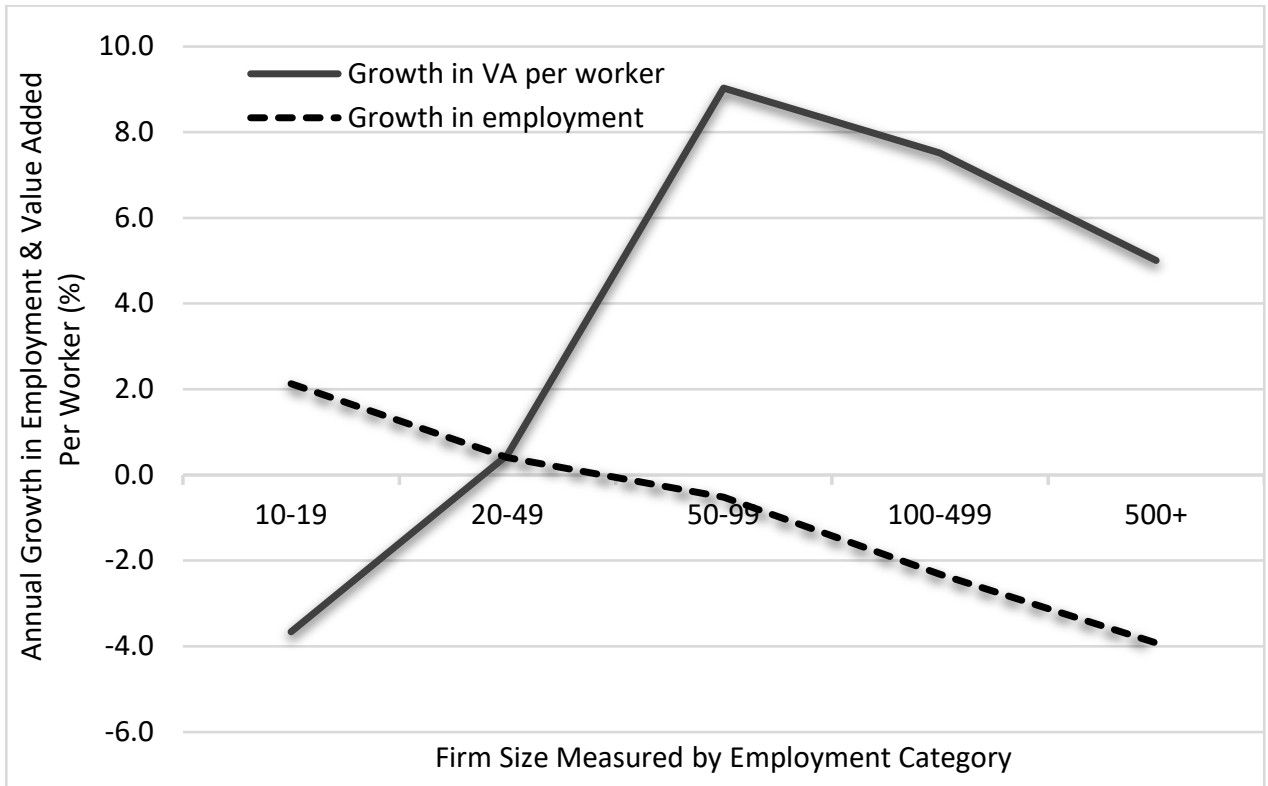

Notes: The estimated growth rates plotted in this figure come from a estimation similar to that used in Tables 4.24.3 col. 1, except we include industry controls here and run the regressions separately for each size group, using a more disaggregated measure of firm size than our 50 worker cutoff. We assign a firm to size groups according to its average employment in the first two years observed. 
Figure A2. Ethiopia estimated growth in VAPW and Employment by Firm Size Group

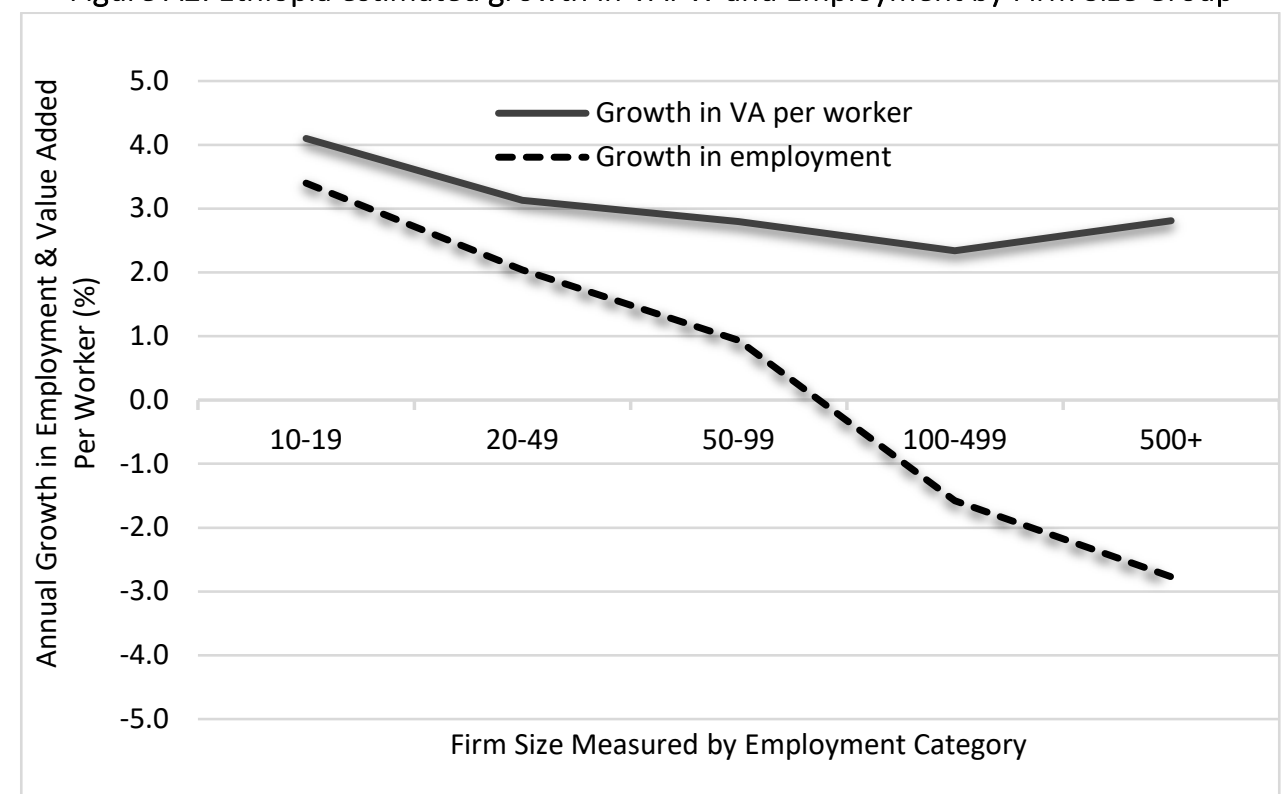

Notes: The estimated growth rates plotted in this figure come from a estimation similar to that used in Tables 4.2$4.3 \mathrm{col}$. 1, except we include industry controls here and run the regressions separately for each size group, using a more disaggregated measure of firm size than our 50 worker cutoff. We assign a firm to size groups according to its average employment in the first two years observed. 
Figure A3. Robustness test of capital deflators for Tanzania and Ethiopia

TZA manufacturing capital-labor ratios, $\$ 1000$ constant 2010 PPP

70.0

60.0

50.0

40.0

30.0

20.0

10.0

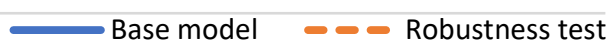

0.0

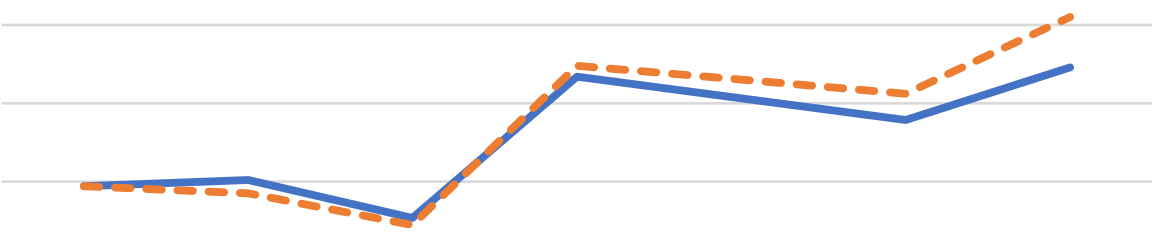

\begin{tabular}{|c|c|c|c|c|c|c|}
\hline & & & 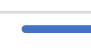 & se model & $-\infty$ & Robustness test \\
\hline 2010 & 2011 & 2012 & 2013 & 2014 & 2015 & 2016 \\
\hline
\end{tabular}

ETH manufacturing capital-labor ratios, $\$ 1000$ constant 2010 PPP

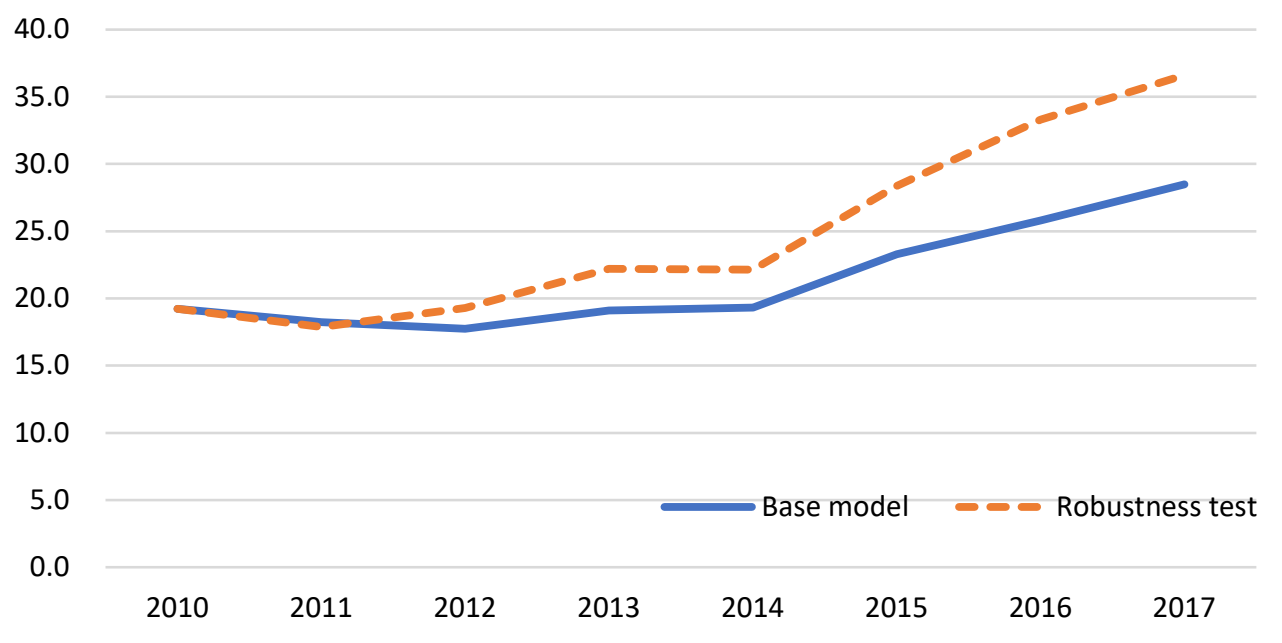

Notes: In the base model, GDP deflator is used for buildings \& structures, while deflator for machinery \& equipment is assumed to one based on CZE situations. In the robustness test, gross capital formation is used as the deflator for both machinery and buildings. This deflator is calculated using gross capital formation data in current and constant LCU from WDI. For ETH the data before 2011 is from UNSD. 
Table A.1: Manufacturing employment shares and growth rates by firm size

\begin{tabular}{|c|c|c|c|}
\hline \multicolumn{4}{|l|}{ Tanzania } \\
\hline & \multicolumn{2}{|c|}{ Share } & \multirow[t]{2}{*}{ Annual growth rate } \\
\hline & 2002 & 2012 & \\
\hline Firms with $10+$ workers & $32.4 \%$ & $19.2 \%$ & $2.5 \%$ \\
\hline Firms with less than 10 workers & $67.6 \%$ & $80.8 \%$ & $9.9 \%$ \\
\hline Total & & & $8.0 \%$ \\
\hline \multicolumn{4}{|l|}{ Ethiopia } \\
\hline & \multicolumn{2}{|c|}{ Share } & Annual growth rate \\
\hline & 2002 & 2016 & \\
\hline Firms with $10+$ workers & $23.6 \%$ & $7.4 \%$ & $0.7 \%$ \\
\hline Firms with less than 10 workers & $76.4 \%$ & $92.6 \%$ & $10.9 \%$ \\
\hline Small firms with powered machines & $12.6 \%$ & $31.7 \%$ & $16.8 \%$ \\
\hline Cottage/Non-farm Enterprises & $63.8 \%$ & $61.0 \%$ & $9.0 \%$ \\
\hline Total & & & $9.4 \%$ \\
\hline \multicolumn{4}{|c|}{$\begin{array}{l}\text { Notes: TZA: (1) Data for firms with 10+ workers in } 2002 \text { is based on UNIDO. (2) Data for } \\
\text { firms with 10+ workers in } 2012 \text { is from ASIP. (3) Data for total manufacturing } \\
\text { employment are from the } 2002 \text { and } 2012 \text { population census. (4) Numbers for firms with } \\
\text { less than } 10 \text { employees are calculated as the difference between total manufacturing } \\
\text { employment from the census and ASIP. ETH: (1) Data for firms with } 10+\text { workers are } \\
\text { from LMSM and both permanent and temporary workers are included. (2) Data for smal } \\
\text { firms with <10 workers which use powered machinery are from SSI and and include } \\
\text { seasonal workers and owners. The number for } 2016 \text { is calculated using the annual } \\
\text { growth rate between } 2008 \text { and } 2014 \text {, the two years with SSI micro data available closest } \\
\text { to 2016. (3) Data for cottage/non-farm enterprises in } 2002 \text { is a residual using total } \\
\text { manufacturing employment from GGDC minus data from LSMS and ISS. (4) Data for } \\
\text { cottage/non-farm enterprises in } 2016 \text { is estimated using the data from LSMS-ISA. }\end{array}$} \\
\hline
\end{tabular}


Table A.2: Capital-Labor ratios for selected EU countries, and Tanzania and Ethiopia, 2010-2017 averages

\begin{tabular}{|c|c|c|c|c|c|c|}
\hline & \multicolumn{3}{|c|}{$\$ 1,000$ constant 2010 US\$ } & \multicolumn{3}{|c|}{$\$ 1,000$ constant 2010 PPP $\$$} \\
\hline & $\begin{array}{l}\text { Machinery \& } \\
\text { equipment/ } \\
\text { Labor }\end{array}$ & $\begin{array}{c}\text { Buildings \& } \\
\text { Structures/ } \\
\text { Labor }\end{array}$ & $\begin{array}{c}\text { M\&E and } \\
\text { B\&S } \\
\text { /Labor }\end{array}$ & $\begin{array}{c}\text { Machinery \& } \\
\text { equipment/ } \\
\text { Labor }\end{array}$ & $\begin{array}{c}\text { Buildings \& } \\
\text { Structures/ } \\
\text { Labor }\end{array}$ & $\begin{array}{c}\text { M\&E and } \\
\text { B\&S } \\
\text { /Labor }\end{array}$ \\
\hline \multicolumn{7}{|l|}{ Total Manufacturing } \\
\hline HUN & 39.4 & 37.9 & 77.4 & 41.0 & 73.6 & 114.5 \\
\hline CZE & 40.0 & 42.7 & 82.7 & 36.5 & 69.6 & 106.1 \\
\hline ESP & 129.0 & 156.7 & 285.7 & 113.6 & 236.7 & 350.3 \\
\hline ITA & 79.6 & 47.3 & 126.9 & 70.8 & 64.3 & 135.1 \\
\hline NLD & 144.4 & 62.6 & 207.0 & 121.2 & 66.2 & 187.4 \\
\hline GBR & 76.5 & 55.2 & 131.7 & 74.6 & 62.5 & 137.1 \\
\hline \multicolumn{7}{|l|}{ Tanzania } \\
\hline Total & 11.4 & 4.8 & 16.2 & 9.3 & 35.8 & 45.1 \\
\hline Small & 7.2 & 3.6 & 10.8 & 5.9 & 27.3 & 33.2 \\
\hline Large & 12.1 & 5.0 & 17.1 & 10.0 & 37.5 & 47.4 \\
\hline Foreign & 14.4 & 4.3 & 18.8 & 11.9 & 32.3 & 44.2 \\
\hline Exporting & 14.8 & 4.5 & 19.4 & 12.2 & 34.0 & 46.1 \\
\hline Top $10 \% \mathrm{~K} / \mathrm{L}$, large & 71.7 & 26.4 & 98.1 & 58.9 & 197.8 & 256.6 \\
\hline Mid $80 \% \mathrm{~K} / \mathrm{L}$, large & 8.2 & 3.6 & 11.8 & 6.7 & 27.2 & 34.0 \\
\hline Bottom $10 \% \mathrm{~K} / \mathrm{L}$, large & 4.3 & 1.2 & 5.5 & 3.5 & 9.1 & 12.6 \\
\hline New large & 14.1 & 6.8 & 20.9 & 11.6 & 50.7 & 62.3 \\
\hline Old large & 10.3 & 3.6 & 13.8 & 8.4 & 26.9 & 35.3 \\
\hline \multicolumn{7}{|l|}{ Ethiopia } \\
\hline Total & 6.1 & 3.0 & 9.0 & 4.3 & 17.1 & 21.4 \\
\hline Small & 2.9 & 2.2 & 5.1 & 2.0 & 12.9 & 14.9 \\
\hline Large & 6.6 & 3.1 & 9.8 & 4.7 & 17.9 & 22.6 \\
\hline Foreign & 10.4 & 3.7 & 14.1 & 7.3 & 21.6 & 28.9 \\
\hline Exporting & 8.4 & 2.9 & 11.3 & 5.9 & 16.5 & 22.4 \\
\hline Top $10 \% \mathrm{~K} / \mathrm{L}$, large & 25.5 & 11.1 & 36.6 & 17.9 & 64.0 & 81.9 \\
\hline Mid 80\% K/L, large & 4.5 & 2.2 & 6.8 & 3.2 & 12.9 & 16.0 \\
\hline Bottom $10 \% \mathrm{~K} / \mathrm{L}$, large & 2.5 & 1.0 & 3.4 & 1.7 & 5.6 & 7.3 \\
\hline New large & 7.4 & 3.5 & 11.0 & 5.2 & 20.3 & 25.5 \\
\hline Old large & 5.3 & 2.6 & 7.9 & 3.7 & 14.8 & 18.5 \\
\hline
\end{tabular}

Notes: Data for the six EU countries are from EU KLEMS 
Table A.3: Capital-Labor ratios for selected sectors, 2010-2017 averages

\begin{tabular}{|c|c|c|c|c|c|c|}
\hline & \multicolumn{3}{|c|}{$\$ 1,000$ constant 2010 USD } & \multicolumn{3}{|c|}{$\$ 1,000$ constant 2010 PPP } \\
\hline & $\begin{array}{c}\text { Machinery \& } \\
\text { equipment/ } \\
\text { Labor }\end{array}$ & $\begin{array}{c}\text { Buildings \& } \\
\text { Structures/ } \\
\text { Labor }\end{array}$ & $\begin{array}{c}\text { M\&E and } \\
\text { B\&S / Labor }\end{array}$ & $\begin{array}{c}\text { Machinery \& } \\
\text { equipment/ Labor }\end{array}$ & $\begin{array}{c}\text { Buildings \& } \\
\text { Structures/ Labor }\end{array}$ & $\begin{array}{c}\text { M\&E and } \\
\text { B\&S / Labor }\end{array}$ \\
\hline \multicolumn{7}{|c|}{ Food products, beverages and tobacco } \\
\hline CZE & 32.7 & 57.4 & 90.1 & 29.8 & 93.6 & 123.4 \\
\hline ESP & 77.5 & 133.9 & 211.4 & 68.2 & 202.3 & 270.5 \\
\hline ITA & 93.3 & 40.0 & 133.3 & 83.0 & 54.3 & 137.3 \\
\hline NLD & 165.6 & 74.7 & 240.3 & 139.0 & 78.9 & 217.9 \\
\hline GBR & 74.5 & 64.8 & 139.3 & 72.7 & 73.4 & 146.1 \\
\hline \multicolumn{7}{|l|}{ Tanzania } \\
\hline Total & 10.2 & 4.0 & 14.2 & 8.4 & 29.9 & 38.3 \\
\hline Small & 9.1 & 5.2 & 14.3 & 7.4 & 39.2 & 46.6 \\
\hline Large & 10.5 & 3.9 & 14.4 & 8.6 & 29.3 & 37.9 \\
\hline Foreign & 12.5 & 3.0 & 15.5 & 10.3 & 22.4 & 32.7 \\
\hline Exporting & 11.2 & 4.9 & 16.1 & 9.2 & 36.8 & 45.9 \\
\hline \multicolumn{7}{|l|}{ Ethiopia } \\
\hline Total & 11.9 & 3.8 & 15.7 & 5.7 & 21.8 & 27.5 \\
\hline Small & 7.9 & 3.6 & 11.5 & 3.1 & 20.6 & 23.7 \\
\hline Large & 13.3 & 3.9 & 17.2 & 6.6 & 22.5 & 29.1 \\
\hline Foreign & 27.9 & 5.4 & 33.3 & 15.8 & 31.0 & 46.8 \\
\hline \multicolumn{7}{|c|}{ Rubber and plastics products, and other non-metallic mineral products } \\
\hline$\overline{C Z E}$ & 39.7 & 55.9 & 95.6 & 36.2 & 91.1 & 127.3 \\
\hline ESP & 111.6 & 162.1 & 273.7 & 98.3 & 244.9 & 343.2 \\
\hline ITA & 104.3 & 50.6 & 155.0 & 92.8 & 68.7 & 161.5 \\
\hline NLD & 167.2 & 52.8 & 220.0 & 140.3 & 55.8 & 196.1 \\
\hline GBR & 63.3 & 42.6 & 105.9 & 61.7 & 48.2 & 110.0 \\
\hline \multicolumn{7}{|l|}{ Tanzania } \\
\hline Total & 30.8 & 9.2 & 39.9 & 25.3 & 68.9 & 94.2 \\
\hline Small & 7.9 & 3.1 & 11.0 & 6.5 & 23.3 & 29.8 \\
\hline Large & 38.5 & 11.5 & 50.0 & 31.6 & 86.3 & 117.9 \\
\hline Foreign & 50.9 & 15.9 & 66.9 & 41.8 & 119.5 & 161.3 \\
\hline \multicolumn{7}{|l|}{ Ethiopia } \\
\hline Total & 11.1 & 3.5 & 14.6 & 5.3 & 20.2 & 25.5 \\
\hline Small & 5.2 & 1.5 & 6.7 & 2.6 & 8.8 & 11.4 \\
\hline Large & 13.2 & 4.2 & 17.3 & 6.3 & 24.1 & 30.4 \\
\hline Foreign & 14.3 & 4.8 & 19.1 & 6.6 & 27.8 & 34.4 \\
\hline \multicolumn{7}{|c|}{ Textiles, wearing apparel, leather and related products } \\
\hline$\overline{C Z E}$ & 22.1 & 32.9 & 55.0 & 20.2 & 53.6 & 73.7 \\
\hline ESP & 43.8 & 74.3 & 118.1 & 38.6 & 112.3 & 150.8 \\
\hline ITA & 31.4 & 19.2 & 50.6 & 28.0 & 26.0 & 54.0 \\
\hline NLD & 94.4 & 49.3 & 143.7 & 79.2 & 52.1 & 131.4 \\
\hline GBR & 24.3 & 35.1 & 59.3 & 23.7 & 39.7 & 63.4 \\
\hline \multicolumn{7}{|l|}{ Tanzania } \\
\hline Total & 7.9 & 3.1 & 11.0 & 6.5 & 23.0 & 29.5 \\
\hline Small & 4.5 & 1.5 & 5.9 & 3.7 & 11.0 & 14.7 \\
\hline Large & 8.2 & 3.2 & 11.4 & 6.7 & 23.8 & 30.6 \\
\hline Foreign & 7.0 & 4.0 & 11.0 & 5.8 & 29.7 & 35.4 \\
\hline \multicolumn{7}{|l|}{ Ethiopia } \\
\hline Total & 5.7 & 1.9 & 7.6 & 2.7 & 10.9 & 13.6 \\
\hline Small & 5.5 & 1.7 & 7.3 & 2.7 & 10.0 & 12.7 \\
\hline Large & 5.8 & 1.9 & 7.7 & 2.7 & 11.0 & 13.7 \\
\hline Foreign & 6.2 & 1.7 & 8.0 & 3.1 & 10.0 & 13.2 \\
\hline Exporting & 7.1 & 2.1 & 9.1 & 3.5 & 11.9 & 15.4 \\
\hline
\end{tabular}

Notes: HUN's sector data is not available. 